University of San Diego

Digital USD

2010-05-01

\title{
Understanding Charter School Governance: A Case Study of a Conversion Charter School Board of Directors
}

David Mark Silver PhD

University of San Diego

Follow this and additional works at: https://digital.sandiego.edu/dissertations

Part of the Leadership Studies Commons

\section{Digital USD Citation}

Silver, David Mark PhD, "Understanding Charter School Governance: A Case Study of a Conversion Charter School Board of Directors" (2010). Dissertations. 817.

https://digital.sandiego.edu/dissertations/817

This Dissertation: Open Access is brought to you for free and open access by the Theses and Dissertations at Digital USD. It has been accepted for inclusion in Dissertations by an authorized administrator of Digital USD. For more information, please contact digital@sandiego.edu. 


\title{
UNDERSTANDING CHARTER SCHOOL GOVERNANCE: A CASE STUDY OF A CONVERSION CHARTER SCHOOL BOARD OF DIRECTORS
}

\author{
by \\ DAVID MARK SILVER \\ A dissertation submitted in partial fulfillment \\ of the requirements for the degree of \\ Doctor of Philosophy \\ University of San Diego
}

May 2010

Dissertation Committee

Lea Hubbard, Ph.D., Chair

Frank Kemerer, Ph.D., Member

Joi Spencer, Ph.D., Member 
(C) Copyright by David Mark Silver All Rights Reserved 


\begin{abstract}
The charter school movement has been at the forefront of educational reform since the 1990s. The majority of charter school research has focused on academic achievement and issues of access, equity, and funding. Less attention has focused on charter school governance, yet evidence suggests that governance challenges represent a significant impediment to the long-term sustainability of this movement.

This qualitative case study examined the operations of a board of directors in a conversion charter school. The study included observations of monthly board of directors meetings over a 16-month period (February 2008-June 2009), interviews with members of the board of directors and representatives from other key internal and external constituent groups, and document analysis of official charter school materials, including minutes, agendas, and historical documents. The period proved to be a turbulent one, with the resignation of the founding executive director, a failed search for her replacement, the dissolution of the university partnership, and the resignation of nearly half the board at the end of the period.
\end{abstract}

The findings reveal three tensions at the heart of the conversion charter school governance structure - governance $v$ management, transparency $v$ confidentiality, and representation $v$ trusteeship. Exploration of these tensions, and the ways they manifested themselves during the 16-month period, suggest several areas for continuing focus for both charter school researchers and practitioners: building the leadership capacity of boards and executive directors; analyzing Sunshine Laws, such as the Brown Act, with an eye toward helping boards more effectively manage these complex requirements; and 
finding ways to proactively and more effectively manage partnerships, particularly university partnerships. 


\section{DEDICATION}

To Carla—my wife and best friend - thank you for your tireless support, encouragement, and love. 


\section{ACKNOWLEDGMENTS}

I would like to acknowledge:

Dr. Lea Hubbard, who encouraged my participation in this research project and who recognized that this would become my dissertation topic long before I even knew where I was headed. Despite being more than 500 miles away this past year, she guided me through the ups and downs of writing and revising, always offering critical feedback and support. I am fortunate to have her as a mentor and friend.

Dr. Paula Cordeiro, who welcomed me into this program and who supported me throughout the last 4 years in ways both big and small. I am extremely grateful for her guidance and wisdom.

Dr. Frank Kemerer, Dr. Joi Spencer, and Dr. Cathy Hands who supported me through the proposal and dissertation stages and offered insightful feedback that significantly improved the final product that appears here.

My wife, Carla, and my three children-Piper, Jackson, and Lily_for allowing me to pursue this goal and for supporting me throughout the process. 


\section{TABLE OF CONTENTS}

PAGE

ACKNOWLEDGMENTS $\ldots \ldots \ldots \ldots \ldots \ldots \ldots \ldots \ldots \ldots \ldots \ldots \ldots \ldots \ldots \ldots$ viii

\section{CHAPTER}

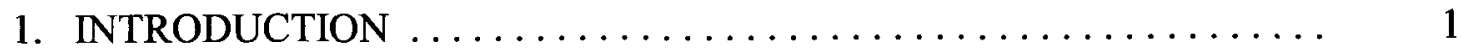

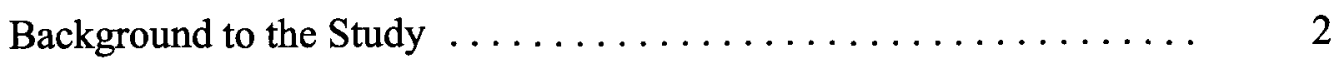

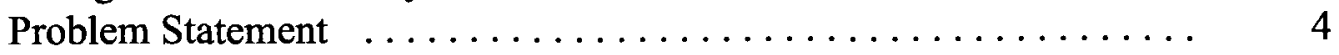

NCLB-Mandated Conversion Charter Schools . . . . . . . . . 6

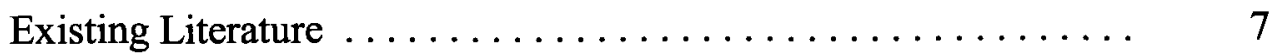

Purpose of the Study $\ldots \ldots \ldots \ldots \ldots \ldots \ldots \ldots \ldots \ldots \ldots \ldots \ldots$

Research Questions $\ldots \ldots \ldots \ldots \ldots \ldots \ldots \ldots \ldots \ldots \ldots \ldots \ldots$

2. REVIEW OF LITERATURE $\ldots \ldots \ldots \ldots \ldots \ldots \ldots \ldots \ldots \ldots \ldots \ldots \ldots \ldots \ldots \ldots$

Charter School Reform and the School Choice Movement $\ldots \ldots \ldots .11$

Assessing the Charter School Reform Movement $\ldots \ldots \ldots \ldots \ldots .18$

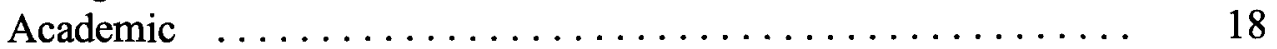

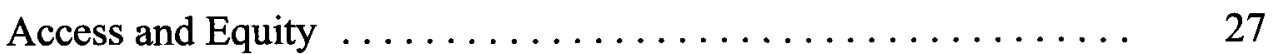

Charter School Governance $\ldots . \ldots \ldots \ldots \ldots \ldots \ldots \ldots \ldots . . \ldots \ldots$

Charter School Governance Structures $\ldots \ldots \ldots \ldots \ldots \ldots \ldots . \quad 32$

Focusing In on Challenges of the Governance Model ....... 36

Relationships with Partner Organizations .............. 40

School-University Partnerships $\ldots \ldots \ldots \ldots \ldots \ldots \ldots \ldots . \quad 44$

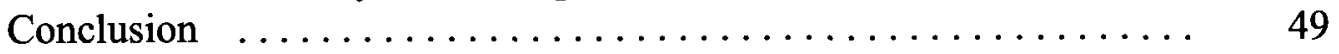

3. RESEARCH METHODOLOGY $\ldots \ldots \ldots \ldots \ldots \ldots \ldots \ldots \ldots \ldots \ldots \ldots \ldots \ldots \ldots$

Board of Directors Meetings $\ldots \ldots \ldots \ldots \ldots \ldots \ldots \ldots \ldots \ldots \ldots \ldots \ldots$

Focus on Early Research $\ldots \ldots \ldots \ldots \ldots \ldots \ldots \ldots \ldots \ldots$

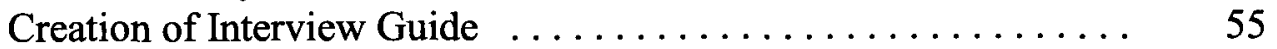

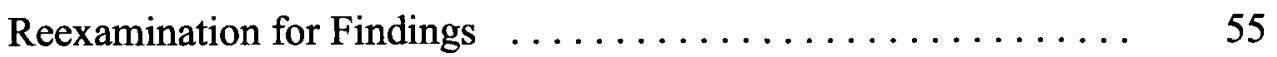

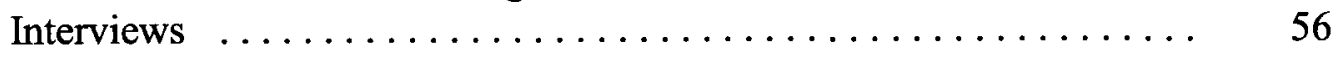

Document Collection $\ldots \ldots \ldots \ldots \ldots \ldots \ldots \ldots \ldots \ldots \ldots \ldots, \quad 58$

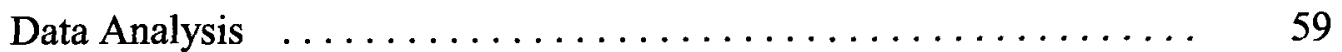

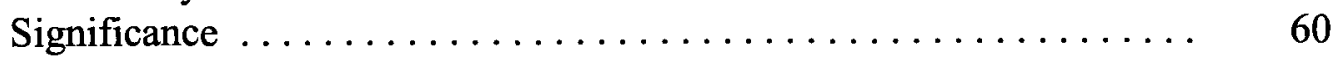

Limitations $\ldots \ldots \ldots \ldots \ldots \ldots \ldots \ldots \ldots \ldots \ldots \ldots \ldots \ldots \ldots \ldots \ldots, 61$

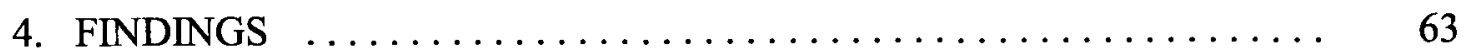

Period 1: Normal Operations $\ldots \ldots \ldots \ldots \ldots \ldots \ldots \ldots \ldots .67$

Management Versus Governance $\ldots \ldots \ldots \ldots \ldots \ldots \ldots \ldots .68$

Fiscal and Facilities Oversight $\ldots \ldots \ldots \ldots \ldots \ldots \ldots \ldots \ldots \ldots \ldots$

Relationship with District $\ldots \ldots \ldots \ldots \ldots \ldots \ldots \ldots \ldots \ldots \ldots \ldots \ldots \ldots$

Accountability ............................... $\quad 75$

University Research $\ldots \ldots \ldots \ldots \ldots \ldots \ldots \ldots \ldots \ldots . \quad 81$ 
Period 2: Tumultuous Times $\ldots \ldots \ldots \ldots \ldots \ldots \ldots \ldots \ldots \ldots, \quad 85$

Confidentiality Versus Transparency $\ldots \ldots \ldots \ldots \ldots \ldots \ldots . \quad 85$

Communication and the Partnership $\ldots \ldots \ldots \ldots \ldots \ldots \ldots . \quad 91$

Period 3: A Troubled Peace $\ldots \ldots \ldots \ldots \ldots \ldots \ldots \ldots \ldots . \ldots . \ldots . \ldots . \ldots$

Board Composition $\ldots \ldots \ldots \ldots \ldots \ldots \ldots \ldots \ldots \ldots \ldots \ldots \ldots \ldots$

Shifting Role Expectations $\ldots \ldots \ldots \ldots \ldots \ldots \ldots \ldots \ldots, \quad 102$

Reframing Earlier Debates $\ldots \ldots \ldots \ldots \ldots \ldots \ldots \ldots \ldots . . \ldots \ldots$

Is the Administrative Structure Sustainable? $\ldots \ldots \ldots \ldots \ldots \ldots \quad 107$

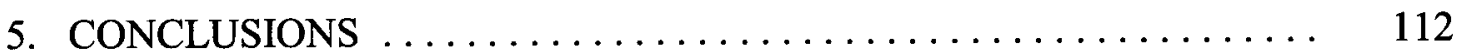

Postscript to Final Meeting $\ldots \ldots \ldots \ldots \ldots \ldots \ldots \ldots \ldots \ldots, 112$

Research Questions Revisited ...................... 114

Contributions to the Literature $\ldots \ldots \ldots \ldots \ldots \ldots \ldots \ldots \ldots . . \ldots \ldots$

Building Leadership Capacity $\ldots \ldots \ldots \ldots \ldots \ldots \ldots \ldots \ldots . \quad 117$

Best Practices for Boards of Directors $\ldots \ldots \ldots \ldots \ldots \ldots \ldots . \quad 118$

The Role of the Executive Director $\ldots \ldots \ldots \ldots \ldots \ldots \ldots . \quad 120$

The Board Chair/Executive Director Relationship .......... 121

Sunshine Laws in Charter Schools $\ldots \ldots \ldots \ldots \ldots \ldots \ldots \ldots \ldots . \quad 123$

University Partnerships $\ldots \ldots \ldots \ldots \ldots \ldots \ldots \ldots \ldots \ldots \ldots . \quad 126$

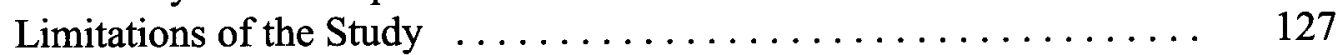

Areas for Future Research $\ldots \ldots \ldots \ldots \ldots \ldots \ldots \ldots \ldots \ldots . \quad 128$

Concluding Remarks $\ldots \ldots \ldots \ldots \ldots \ldots \ldots \ldots \ldots \ldots \ldots$

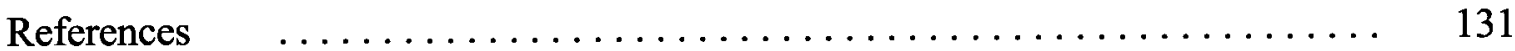

Appendix

A. Board Meetings Attended $\ldots \ldots \ldots \ldots \ldots \ldots \ldots \ldots \ldots \ldots \ldots, \quad 140$

B. Analysis of Interview Guide and Rationale for Each Question $\ldots \ldots \ldots \quad 142$ 


\section{CHAPTER 1}

\section{INTRODUCTION}

\section{Background to the Study}

In the winter of 2004-2005, San Diego Middle School (SDMS), a pseudonym, was forced to make a choice. Following 6 years as a failing school under the federal No Child Left Behind (NCLB) legislation, the school had to choose one of four fates-it could allow the district to take it over, it could seek out an outside group to assume control, it could make some type of fundamental reform involving the restructuring of the school's governance arrangement, or it could submit a proposal to become a conversion charter school. The school gathered a working group of teachers, community members, and parents to consider its options and ultimately decided to petition to become a charter school. Several months of community education, signature gathering, and bureaucratic wrangling followed, ultimately ending with a successful petition to the San Diego Unified School District governing board and the opportunity to become a conversion charter school starting in the 2005-2006 school year. According to the founding principal, the desire to become a charter school reflected a desire to be in control, to allow the school to make its own decisions about how it operated. She recounted the things that the working committee had described as important in enabling the school to transform itself into their "dream vision."

One was being in charge of our budget, one was being in charge of our curriculum and materials, one was being in charge of the calendar and the length of the day and the instructional design, and, most important, one really was being in charge of who was here, in the classroom and having some say about that without the 
[California Teachers Union interfering]. (SDMS Principal, interview, November 8, 2007)

The ensuing years have, by many indicators, proven extremely successful for the school. Laudatory articles in the press tout the school as one of the only middle schools in California to pull itself out of program improvement (Alpert, 2008; Merrow, 2007). One newspaper suggested that the California Department of Education was studying the school as a model turnaround, quoting a consultant who termed it a "big deal" and a potential case study for other schools (Alpert, 2008). Violence on campus has significantly decreased and what the founding principal and others have described as a campus of chaos has been replaced by a campus order. On the National Public Radio show NewsHour the founding principal explained, "My first day here, I thought, 'Oh, my goodness, what am I in for?' At any point in time, I would see 20 to 100 students just roaming the campus, many stories of setting fires in the bathrooms, destroying property, a campus of chaos" (Merrow, 2007). A board member echoed her sentiments, explaining that the founding principal presented data each month about all types of things, including the number of suspensions. She noted that while it is one or two suspensions per month now, a few years ago it was hundreds. She also noted that another member of the board of directors, a police officer for the city schools, consistently reminded the other members about how much people's perceptions about SDMS had changed. "He always reminds us how word is out in the community, you're not going to find the police at SDMS, and if they are there it's because of something that happened down the street, and they are trying 
to protect the school from it" (Member of Board of Directors, interview, November 16, 2007).

Yet the school's early success in some areas does not necessarily tell the whole story. The publication of the glowing article in a local newspaper, Voice of San Diego, in June 2008 appeared just as the school entered the most turbulent period in its early history. The ensuing months have seen the departure of the founding principal, a failed search to find a replacement, and the dissolution of the partnership between the school and a local university. The challenges focus attention on school governance issues and raise questions about the role of the board of directors in the operation of the school. Between February 2008 and June 2009, the board of directors was comprised of between 11 and 14 members, including local community leaders, parents, faculty members, and representatives from the school's partner university. These men and women, charged with hiring and supporting the principal, holding the principal and the school accountable for its performance, and ensuring the school's fiscal viability and long-term sustainability, represent a significant yet little understood component of the school's reform efforts. The board of directors has been engaged during the early years navigating complex relationships with key external groups (the school district, the school's accounting educational management organization, the partnering university) and internal groups (administration, faculty, parents). Moreover, during the 16-month period of this research, the board found itself at the heart of several significant crises in the life of the school, crises that had the potential to determine the school's long-term viability. The recent 
events have pulled the board of directors out of the shadows, and have raised questions about how school governance impacts charter school reform.

\section{Problem Statement}

Charter schools have played an increasingly significant role in the educational reform conversation during the past few years, yet the central role of governance in the charter school reform effort remains little studied. The vast majority of charter school failures result from "operational mismanagement and financial difficulties" (Smith, Wohlstetter, \& Brewer, 2007, p. 17), suggesting that the impact of governance on charter schools is important to understand in order to determine the sustainability of the charter school movement as a viable long-term reform strategy. Few studies to date however directly address the role of governance in charter schools or offer insight into how governance impacts the reform efforts.

Charter school legislation first appeared in Minnesota in 1991 and in California in 1992 , and has now spread to 40 states. Nationally, there are more than 3,500 charter schools, and California has just over 800 charter schools (California Charter Schools Association, n.d.). At the heart of most charter schools is a charter school board of directors, While a non-profit structure is not necessarily mandated for charter schools in California (California Education Code, 2004), the majority of charter schools nationwide adopt this structure (Henig, Holyoke, Brown, \& Lacireno-Paquet, 2005). The board of directors, representing one part of the classic tripartite non-profit governance system (board of directors, administrator, staff), is responsible for the fiscal health and long-term sustainability of the organization. The board of directors also serves as the linchpin that 
connects the internal (administration, faculty, parents) and external (school district, partnering organizations) worlds of the school. A growing body of charter school consulting literature has offered guidelines to ensure the successful operation of these founding boards. Cornell-Feist's (2007) policy brief for the National Association of Charter School Authorizers (NACSA) is an exemplar, reminding boards that they need to have a "passionate unwavering belief in the school's mission, full board understanding of the key charter promises, shared definition of academic excellence, a clear plan to conduct oversight of the academic program, [and] a clear plan to conduct financial oversight" (n.p.).

Given their central governance role in so many charter schools, charter school boards of directors offer an interesting and helpful lens upon which to better understand the charter school reform effort. Navigating relationships with external groups, such as school districts, educational management organizations (EMOs), and partnering universities, the board of directors has primary responsibility for ensuring the organization's fiscal health and for holding the organization accountable so that it can continually renew its charter. On the other side, the board of directors needs to hire and support an executive director and then make sure the school is managed effectively. A challenging role in any context, the work of a board of directors in a NCLB-conversion charter school is compounded by the need to support and foster dramatic improvements in a historically underperforming school. Furthermore, board members, who are often drawn from the community, may or may not have the skills and experience necessary to navigate through the sometimes tricky terrain. 


\section{NCLB-Mandated Conversion Charter Schools}

Studies have typically lumped charter schools together. Henig et al. (2005) attempt to rectify this by creating a typology based on founder type, although they note in the end that type may have little impact on the operations of the schools. As they write, "the external environment and core educational tasks may impose similar patterns of behavior on charter schools regardless of their differing organizational roots" (p. 515). Henig et al. identified seven different varieties-educational management organization (EMO) only, EMO and other, local business, educators, social service, parent or community, non-EMO mix. Overarching this framework was a distinction between forprofit and non-profit charter schools, or as they characterized it, mission-driven versus market-driven schools, with the first two types representing for-profit schools and the other five representing non-profit schools. Their study suggested the overwhelming majority of charter schools, more than $80 \%$, are non-profits.

Henig et al.'s (2005) typology fails to account for one of the newest charter school types, conversion charter schools created as a result of the federal No Child Left Behind legislation. The No Child Left Behind legislation forces schools that have failed to meet adequate yearly progress (AYP) for 5 straight years to make a choice in year 6 between:

(i)Reopening the school as a public charter school. (ii) Replacing all or most of the school staff (which may include the principal) who are relevant to the failure to make adequate yearly progress. (iii) Entering into a contract with an entity, such as a private management company, with a demonstrated record of effectiveness, to operate the public school. (iv) Turning the operation of the school over to the State educational agency, if permitted under State law and agreed to by the State. (v) Any other major restructuring of the school's governance arrangement that makes fundamental reforms, such as significant changes in the school's staffing and governance, to improve student academic achievement in the school and that 
has substantial promise of enabling the school to make adequate yearly progress as defined in the State plan under section 1111(b)(2). (U.S. Department of Education, 2001, n.p.)

Thus, NCLB-inspired conversion charter schools represent a community-wide Hail Mary to save a persistently underperforming school. Created under duress, these schools are last ditch efforts by a community to create success in locations that have consistently experienced failure.

Smith (2007) notes that very few school districts have actually utilized option "i," reopening as a charter, preferring instead to turn to option " $\mathrm{v}$ " which he argues allows a great deal of discretion in its implementation. Indeed, in the San Diego Unified School District, only 3 of the district's 37 charter schools are conversion charter schools (CCSA Representative, interview, March 2009). Even if the creation of NCLB-mandated conversion charter schools remains rare, better understanding these conversion charter schools and their performance in their early years offers an important avenue into understanding this school reform option intended to help students in schools that have faced some of the most persistent challenges within the public education system.

\section{Existing Literature}

A number of studies have analyzed various components of the charter school governance structure. Teske, Schneider, and Cassese (2005) examine the essential role of authorizing agents in the charter school governance model. Slayton (2002) and Wells, Vasudeva, Holmes, and Cooper (2002) focus on one particular authorizing agent - the school district. All three studies raise questions about the current capacity of school districts to support charter schools, noting the inherent tension in asking school districts 
to provide services for charter schools, which are essentially founded on the philosophical premise that the traditional school bureaucracy is broken and incapable of creating successful schools.

A number of studies have unearthed other challenges that charter schools have faced in the early years. Miron and Nelson (2002), Slayton (2002), Osberg (2006), and Speakman (2008) point for example to funding inequities that impact charter schools, noting that charter schools typically receive less money than their public school counterparts. Hill's (2006) edited volume Charter Schools Against the Odds stresses the almost heroic quality of charter school reform, which has survived despite a panoply of obstacles, including inadequate funding, poor facilities, limits on the number of charter schools allowed in a state, and hostile schools boards and teachers unions. Echoing Hill's findings, Williams (2007) suggested that charter schools have been actively sabotaged at every turn by "entrenched school boards, teachers unions, and principals resistant to any competition" (p. 1).

Scott and Holmes (2002) have argued that charter school reform has actually exacerbated inequality, by providing less funding to charter schools that, in turn, have less ability to raise additional funds to cover the gap. As they write, "charter school reform is unique in that it leaves partially 'public funded' schools starved for resources to pay for fundamental things, such as buildings and equipment ... Thus, charter schools exist within a policy framework that leaves them no choice but to scramble for private resources" (p. 126). 
In the end, the current research suggests that the board of directors is a vital component of charter school reform, yet little has been done to analyze in depth the role the board of directors plays. Ultimately, the long-term health and sustainability of the charter school reform movement hinges, at least in part, on the success of these littleunderstood, and yet extremely influential, governing bodies.

\section{Purpose of the Study}

This case study, conducted over a 16-month period, will contribute to our understanding of charter schools by focusing on the actions of a school board of directors organized to support an NCLB-mandated conversion charter school. The study will analyze the work that is undertaken by the board of directors during the school's early years, paying particular attention to the role the board of directors played in the school's growth and development. The study will provide insight into some of the challenges faced by this young charter school, including working with the district office, navigating relationships with its partner university, and ensuring the school's academic and fiscal health, and will look at what role the board played in each of these situations. In the end, the study will attempt to see in practice the results of providing greater autonomy coupled with increasing accountability that lie at the heart of the charter school experiment.

\section{Research Questions}

In order to examine the board of directors' experience, the following research questions will guide the investigation:

- What role did the non-profit board of director's play at SDMS? What actions did they take to reform the school? 
- How did a non-profit board of directors impact the reform efforts for an NCLB-mandated conversion charter school?

Sub-questions will include:

- How does the board of directors interpret its role as governing body for this charter school? What actions do they take to support the school?

- How do various constituent groups (administration, faculty, parents) perceive the board of directors? What are the consequences of these perceptions?

- What are the primary challenges faced by the school and what role does the board of directors play vis a vis each of these issues?

- How does the board of directors manage relationships with key external groups (school district, the financial EMO, the partnering university) and internal groups (the executive director, the faculty, and the parents)?

- How does the board of directors manage its legal and fiduciary responsibilities? 


\section{CHAPTER 2}

\section{REVIEW OF THE LITERATURE}

This literature review will bring several different strands of scholarship together in an attempt to locate this study within the current research on school reform, charter schools and school governance. The first section will examine the historical roots of the charter school movement and the place of this movement in the broader context of the school choice movement. The second section will explore the efforts of scholars and policymakers to assess the effectiveness of the charter school movement, focusing on the questions that have driven charter school research and offering insights into both the strengths and limitations of the current body of work. The final section will provide an examination of the charter school governance structure. Starting with a brief historical look at governing boards in general, the section will then explore the different components of the charter school governance structure, particularly the board of directors and the attendant challenges that this governance structure creates. A look at the role of partnerships, specifically university/K12 partnerships, will also be included in the final section as it offers insight into one of the more complex challenges-managing a partnership - that can face a charter school board.

\section{Charter School Reform and the School Choice Movement}

The charter school reform movement started in the early 1990s. Initial legislation passed first in Minnesota in 1991 and then California in 1992; by the end of the 20052006 school year, there were more than 3,500 charter schools in 40 states and Washington, DC (Berends, Springer, \& Walberg, 2008; Miron \& Nelson, 2002). 
Understanding this relatively new phenomenon has proven exceedingly challenging, as charter schools represent an extremely diverse set of institutions. As Fuller (2000) notes, "charter schools are so diverse . . . that it's difficult to advance generalized claims about this far-flung movement" (p. 4). Furthermore, competing accounts of charter schools, particularly in the popular press, often present them as, on one hand, an educational silver bullet or, on the other, an overhyped and unmitigated failure. Thus, despite the challenges, it is imperative that scholars continue to try to offer a more balanced explanation.

Charter school reform is one component of the broader school choice movement that has existed in some form or other for more than 50 years. Bulman and Kirp (1999) trace the movement's roots to the free-market voucher plan of conservative economist Milton Friedman back in the 1950 s, although they note that choice generated little political traction until the 1970 s when it reappeared in the guise of magnet schools and opened the possibility of using choice to achieve agendas that extended beyond market economics, including integration and pedagogical innovation. Bulman and Kirp highlight efforts like the Milwaukee Parental Choice Program, which was launched in the early 1990s. The program offered public funds to poor inner-city students, allowing them to enroll in private schools. This program essentially combined market-based and equitybased school reform efforts, and created a rather strange group of bedfellows, bringing together "liberal black Democrats and conservative white Republicans" (p. 49). The key concept in this approach as well as several other efforts, as described by scholars like 
Coons and Sugarman (1978), was the notion of using choice in the form of vouchers as a means of increasing equity, not simply as a part of a free-market ideological stance.

Several other scholars emphasize the choice movement's connection to the broader societal effort to decentralize the state that occurred throughout the early 1990 s (Buckley \& Schneider, 2007; Fuller, 2000; Miron, Nelson, \& Lubienski, 2002). They point in particular to Chubb and Moe's (1990) Politics, Markets, and America's Schools, which offered a "fresh diagnosis of the political constraints strangling public education" (Fuller, 2000, p. 19). Chubb and Moe advance the proposition that "the specific kinds of democratic institutions by which American public education has been governed for the last half century appear to be incompatible with effective schooling" (p. 2). They argued that current educational reform efforts were doomed from the start for they attempted to make changes within an institutional structure that was fundamentally flawed. They suggested that while reformers in many cases accurately identified the elements necessary for successful schools, such as "clear school goals, rigorous academic standards ... strong leadership by the principal, teacher participation in decisionmaking" (p. 16), they failed to understand what needed to happen in order to create those types of schools. Chubb and Moe argued for a market-driven system that puts parents and students at the core, as opposed to the existing system of democratic control which was "governed by an enormous far-flung constituency in which the interests of parents and students carry no special status or weight" (p. 35). They envisioned a voucher system geared toward removing almost all higher level authority from the educational system, and placing 
authority with individual schools that would be free to compete and operate in whatever manner seemed most effective and would draw the most students.

While some choice advocates touted vouchers, others turned to the concept of charters. Guided at least in part by the same impetus for market-driven reform as the voucher advocates, charter advocates envisioned a system that would give parents and students increased autonomy from the school system itself by creating what Miron et al. (2002) calls a public/private hybrid that "mixes elements of traditional public schools (universal access and public funding) with elements usually associated with private schools (choice, autonomy, and flexibility)" (p. 2). Bulman and Kirp (1999) also stress the public/private hybrid nature of charter schools.

The arguments of choice advocates have generated resistance. Corwin and Schneider (2005) decry the hoax being perpetrated on people by voucher and charterschool advocates, arguing that effective school reform is not only possible but preferable within existing school districts. While recognizing the benefits of parental choice in schools, they denounce the decision to make these schools separate from the school district. As they write, "Parents can have the right to choose schools without forcing them to leave school districts. Independence was an unnecessary add-on-an artifact of freemarket fantasy" (p. 9). Corwin and Schneider point to the extensive reforms tried in public schools—-"preschool programs, middle schools, year-round calendars, magnet schools, alternative education, school-based management, individual instruction, beforeand after-school interventions, non-graded instruction, team teaching, smaller schools, and work-study programs"- - and suggest that the problem is not an unwillingness to try 
reforms but the tendency for these reforms to be "imposed by outsiders who have little day-to-day stake in schools" (p. 9). Moreover, they suggest that the decision to create independent charter schools was driven by ideology and, in the end, has derailed what could have been a broader and more successful school reform effort.

Others have attempted to take a more balanced approach to the issue. Sugarman and Kemerer's (1999) edited volume offers a number of different lenses upon which to examine the school choice movement. Henig (1999), for example, lays out the basic arguments on the two sides of the choice debate. Henig notes that school choice advocates believe that choice will lead parents to choose schools based on "the quality of the education they provide" (p. 72), thus rewarding good schools and causing poor schools to either reform or perish. Critics, on the other hand, predict that "information about schools will be incomplete, misleading, and unequally distributed" (p. 72). In turn, they fear the creation of a more segregated society and the creation of schools focused more on non-educational outcomes- "protecting their children from threatening ideas," for example-rather than improving learning outcomes. His conclusions, after reviewing the studies available to date, suggest that both advocates and critics may be right, and that policy decisions need to be "unhurried, reasonably cautious, and tied to specific circumstances" (p. 101). He notes that parents when given the choice tend to be happy with their decisions, that information gaps do exist, that racial and class biases in access are quite persistent, but also that when "public policy has intentionally and aggressively set out to do so, racial and class biases associated with unfettered choice have been reduced or even reversed" (p. 76). 
Perhaps more importantly, Henig (1999) points out one of the biggest challenges facing school choice researchers, namely the difficulty of determining if school choice actually leads to improved academic performance. The crux of the problem lies in the nature of choice itself. As Henig writes, "The primary source of selection bias is choice. When subjects are in position to determine whether or not they are exposed to a given policy instrument, attributes related to that choice-rather than the policy itself- might account for any difference between them and a comparison group that has not receive the policy stimulus" (p. 90). In other words, even if the performance of students in choice schools is shown to be better than students in traditional public schools the characteristics of these students that led them to choose to attend these schools may be more significant than anything that the school itself does.

Looking from a slightly different perspective, Sugarman (1999) notes that school choice may be able to accomplish what years of reform efforts have been unable to accomplish, namely the elimination of public school finance inequalities. Sugarman and his fellow school finance reformers have argued for years a simple point - in the current school funding structure, "wealth matters too much" (p. 114). He points out the inequities created by a funding model that relies heavily on local income taxes and that results in significant disparities across districts and states. He also highlights the less often noted disparities within districts, including inferior facilities and a lower-paid teacher corps. Sugarman's hope is that school choice will create complexities in this funding scheme that will drive broader change. For example, he notes, that state funding of charter schools may become a reality, as charter school operators tire of battling district officials 
and district officials grow leery of funding schools that may draw significant numbers of students from outside the district. State funding, in turn, may lead to all types of questions about how to determine appropriate funding levels and, thus, in the end may result in reforms to funding. Unfortunately, Sugarman also notes the alternative is also possible, with the result that "conventional school finance arrangements may strangle efforts to expand choice in the public sector" (p. 124). The possibility that school choice reform will actually founder on the rocks of school finance is something that will resurface later in discussions of charter school challenges.

The National Center for the Study of Privatization in Education (NCSPE) at Teachers College, Columbia University, has sought to provide a theoretical framework to help understand the broader choice movement. Their framework considers four major goals for education - freedom of choice, productive efficiency, equity, and social cohesion (Belfield \& Levin, 2005). They note that these goals can be conflicting and thus there is no one perfect system. While some voucher programs may strongly enhance freedom of choice and productive efficiency, for example, they may in turn negatively impact equity and social cohesion. Alternatively, other voucher plans that attempt to increase equity and social cohesion may have to create some limitations in terms of choice. Somewhat discouragingly, the authors note that the current research results concerning privatization are "equivocal" and that, in the end, the results of the debate are more likely to turn on the political will of powerful constituencies - the teacher's unions and business interests, for example - rather than on the empirical evidence that researchers are able to generate (Belfield \& Levin, 2005, p. 57). 
Taken together, the school choice literature raises several issues that also emerge in an analysis of charter schools - the promises represented by choice and increased autonomy coupled with the challenges of finding effective ways to empirically measure the actual results of reform efforts; the potential negative impact of choice on equity and social cohesion; the financial and governance challenges created in the implementation of new choice systems; the limited ability of schools to handle often unforeseen and poorly understood roadblocks, and the ultimately devastating effect these challenges can have on reform efforts.

\section{Assessing the Charter School Reform Movement}

While charter schools have taken on different forms in different states, the basic premise of charter schools has been consistent. From the beginning, charter schools have made bold promises about what they will be able to accomplish. According to the US Charter school web site (n.d.), charter schools will:

- Increase opportunities for learning and access to quality education for all students;

- Create choice for parents and students within the public school system;

- Provide a system of accountability for results in public education;

- Create new professional opportunities for teachers;

- Encourage community and parent involvement in public education;

- Leverage improved public education broadly. (U.S. Charter Schools, n.d., n.p.)

In this section, I will examine two main issues that have constituted the central thrust of charter school research-academic performance and issues of access and equity.

\section{Academic}

The most common - and contentious - area of research has been the effort to track student performance and determine if charter schools improve academic outcomes. The 
focus on academic results reflects the basic bargain at the core of the charter school concept - "enhanced autonomy over curriculum, instruction, and operations" in exchange for increased accountability in terms of student outcomes (Miron \& Nelson, 2002, p. 3). From the beginning, charter school advocates have believed that choice and competition will lead to more innovative and effective schools. The results, however, have been mixed; perhaps the most definitive statement that can be made is that additional research that takes into account the diversity of charter school experiences is still needed.

Several prominent studies have suggested that charter schools are meeting their goals (Greene, Forster, \& Winters, 2003; Hoxby, 2004), while other equally prominent studies have drawn the exact opposite conclusion (Henig, Holyoke, Lacireno-Paquet, \& Moser, 2001; Nelson, Rosenberg, \& Van Meter, 2004). Greene et al. (2003) argued that in order to be valid a study had to compare "apples to apples." They emphasize that studies need to compare scores from charter schools and public schools that serve similar student populations. Using this methodology, the scholars conducted a national empirical study that measured test score improvements from 11 states in "untargeted charter schools serving the general population to their closest neighboring regular public schools" (Greene et al., 2003, p. 1). The results suggested that charter school students performed "moderately better" than their public school counterparts on both math tests (.08 standard deviations or about 3 percentile points from the $50^{\text {th }}$ percentile) and reading tests (.04 standard deviations or about 2 percentile points from the $50^{\text {th }}$ percentile). The logic the researchers employed made sense-it is difficult to compare schools from students 
attending targeted charter schools with other schools since they don't necessarily reflect the same student population.

While the results were encouraging, however, the limitations of the results are also noteworthy. As the authors themselves suggest, charter schools that target specific populations make up a significant portion of the charter school population. The exclusion of these schools, while perhaps logical within the constraints of their study, effectively means that the study provides no effective means of measuring the performance of a significant portion of charter schools. Moreover, the decision to exclude conversion charter schools - regular public schools that converted into charter schools-seems capricious. While their rationale may be true in certain context-conversion charter schools are not necessarily "operating as schools of choice" like other charter schools since some students attend them simply because they are in the neighborhood-the decision to exclude conversion charters seems strange as they represent an excellent means of comparing student performance before and after conversion. Moreover, these schools reflect typical neighborhood populations, not a targeted community, and thus offer a helpful means of comparing charter schools to similar neighborhood public schools. A bigger concern is that the study ignores the impact of selection bias. In other words, while charter school parents choose to attend their schools, parents at the neighborhood school typically do not actively choose their school. Research suggests (Kemerer \& Ausbrooks, 1996) that selection bias plays a significant role in determining student performance in schools. 
Hoxby's (2004) study, one of the most oft-quoted defenses of charter schools to date, analyzed the data of all charter schools students in the nation. Termed a "straightforward comparison of charter schools and regular public schools," the study analyzed the performance of students in charter schools with students in both the nearest neighborhood public school and the nearest regular public school with a similar racial composition (in many cases, she notes, these are one and the same). Thus, like Greene et al. (2003), Hoxby tries to compare students at similar schools. Unlike the Green et al. (2003) study, however, which looks at the score changes over a 2-year period, Hoxby only looks at one year's data, comparing reading and math proficiency data from the 2002-2003 school year. The results are heartening for charter school advocates, with charter students shown to be $4 \%$ more likely to be proficient in reading and $2 \%$ more likely to be proficient in math than students from nearby neighborhood public schools. Moreover, Hoxby shows that the results tend to be even more positive in states where charter schools are well-established. For example, she notes that in California the advantage in reading is $8 \%$ and the advantage in math is $3 \%$.

Hoxby's study was offered as a rebuttal to the widely discussed Nelson et al. (2004) study. Funded by the American Federation of Teachers, the latter study set off a firestorm when it was released. In the opening section of the paper, the authors note that the release of the National Assessment of Education Progress (NAEP) scores for charter schools in 2003 had been delayed and then the plan for the report altered. Indeed, at the time of the study's publication, the results had not yet been released. Despite that, Nelson et al. with a "combination of intuition, prior knowledge, considerable digging and luck" 
were unable to unearth the results prior to their formal publication (p. 3). With this dramatic narrative as background, the authors then reveal the "smoking gun"- according to their analysis, students in charter schools in both grade 4 and grade 8 scored significantly lower than students in regular public schools. In particular, they note that among students eligible for the lunch program (a proxy for low SES students) in both regular public schools and charter schools, students in regular public schools scored nearly 6 scale points higher in $4^{\text {th }}$ grade math, 7 scale points higher in $4^{\text {th }}$ grade reading, and 7 scale points higher in $8^{\text {th }}$ grade math.

Both of these studies have significant limitations. Hoxby's (2004) study, while heartening for charter school advocates, offers only a 1-year snapshot and thus the study does not capture what type of impact charter schools are having over time. Furthermore, the wildly different results between different states, as well as the significant differences between the numbers of students in each state, makes broader conclusions difficult. For example, Alaskan charter school students are about $20 \%$ more likely to be proficient in reading, while Georgia's charter students are about $6 \%$ more likely to be proficient and North Carolina's charter students are about $4 \%$ less likely to be proficient. Nelson et al. (2004) also focus on a 1-year snapshot. In addition, the scope of their study is extremely limited, as their results only examine $3 \%$ of the students in charter schools. As Hoxby notes in a critique of the study, "The sample represents about 4 fourth graders in Connecticut charter schools, 14 in District of Columbia charter schools, 32 in New York charter schools, and 38 in New Jersey charter schools ... . Meaningful comparisons require larger number of students" (n.p.). 
Betts and Hill's (2006) "white paper" for the National Charter School Research Project attempts to navigate through this morass, offering a general assessment of the methodologies employed in studies to date and providing suggestions for future studies that will more effectively measure the effectiveness of charter schools. They note that the primary question driving research into charter school outcomes should not be whether "the average child in a charter school is learning more or less than the average child in a district-run public school," but rather whether "students in charter schools are learning more or less than they would have learned in conventional public schools" (p. 1). The two main challenges to answering this question are that "it is impossible to observe the same students simultaneously in both charter schools and the schools they would have attended had charter schools not been available" (p. 1); and there are many non-school factors that influence student performance (family background, environment, personal traits) that are difficult to isolate when studying student outcomes. They review the various types of studies, noting that each varies in its degree of internal validity- the ability to make "strong statements about the causal effect of attending a charter school"-and external validity - the ability to generalize from the results to charter schools in general.

They point out several types of studies that are particularly ineffective or questionable, including school-level analyses that compare average student test scores across schools at a single point in time, school-level analyses that compare trends over time in average student test scores, and student-level comparisons of test scores at a single point in time. While they note the final model has some advantages over the other two-it at least links an individual student's achievement to his background 
characteristics - this approach "ignores the history of each student, and ignores differences in rates of learning between one student and another" (Betts \& Hill, 2006, p. 12). The first two approaches, on the other hand, ignore the impact of compositional changes in schools, thus making it difficult to draw conclusions from the data without knowing if student movement in and out of schools is driving much of the change. In contrast, Betts and Hill (2006) suggest that individual student studies of valueadded and experimental studies that use lotteries to define a comparison group are significantly more effective, although not without their own limitations. The former approach, which has been increasingly prominent, attempts to measure trends over time by comparing where a student begins on the achievement spectrum with where they end up after a set period of time. As Betts and Hill note, this approach still does not perfectly control for "unobserved characteristics" that make comparisons between students at charter schools and regular public schools misleading. The latter approach, on the other hand, provides a "quasi-experiment" which gets as close as possible to providing a randomized sample, which can be used to compare students who attended the charter and students who applied but were denied admission.

While the internal validity of this model is quite high, the external validity is questionable. As Betts and Hill (2006) note, charter schools that employ a lottery are clearly popular schools and thus might not be particularly representative of charter schools in general. In addition, the students who apply to charter schools may not represent the typical student. Indeed, one might assume that students and their families applying to charter schools may actually be more motivated and have greater family 
support than the typical student, thus raising questions about whether better results for these students will actually translate into better results for other, perhaps more generally representative, students who attended the same school.

Practically speaking, these types of studies are also hard to conduct and the number of sample schools is limited. Indeed, as of 2006, only two such studies existed (Hoxby \& Rockoff, 2005; McClure, Strick, Jacob-Almeida, \& Reicher, 2005). It is worth noting while the Hoxby and Rockoff (2005) study shows significant advantages for the students who attended the charter schools, the McClure et al. (2005) study shows that students at regular public schools and charter schools had in essence identical results. The latter study, which was conducted at the Preuss School in San Diego, suggested there were other benefits that students gained from attending Preuss-Preuss students completed more courses required for admission to UC/CSU schools, for example - yet its results fall short of the ringing endorsement sought by at least some charter school advocates.

These studies also do not account for the role of selection bias. A study of schools in San Antonio (Kemerer \& Ausbrooks, 1996) suggests that students who are not selected often receive a negative impression of themselves and, in turn, do worse in school. This study raises serious questions about the possibility of creating any study which can meaningfully compare student performance in charter schools to student performance in public schools.

The final conclusion reached by Betts and Hill (2006) places student outcome research in a helpful perspective. There are clearly some studies that offer little, if any, 
helpful results for policymakers. Studies that attempt to track student performance at the school level, for example, have significant limitations and thus are likely to provide little in the way of meaningful feedback. Studies that track student performance over time and lottery-based studies, however, have strengths that make them helpful for understanding charter schools but also have limitations that make them far from perfect in determining the effectiveness of the charter-school reform effort. Perhaps most importantly, Betts and Hill point to the dearth of good data, something which can only be rectified by the willingness of district and state school boards and funders to step in and ensure that longitudinal data of student test scores and other key demographic information-racial and ethnic identity, family income, place of residence - are available.

Hassel and Terrell (2006) offer a strikingly similar analysis to Betts and Hill (2006). In Charter School Achievement: What We Know, Hassel and Terrell review 58 comparative analyses of charter school and traditional public school performance. They find that 25 of the 58 studies look only at a snapshot and provide mixed and not especially meaningful results. On the other hand, they argue that the 33 studies that track change over time are, at the least, encouraging. Only 4 of the studies show charter schools lagging behind, while 16 find overall gains that were larger than public school gains, 7 find higher gains in certain categories of schools-such as schools serving at risk students, and 6 find comparable gains between charter schools and regular public schools. Their main conclusion in terms of student achievement mirrors Betts and Hill_-_"we need many more studies that track individual students over time, ideally in a randomized 
experimental setting, but at the very least using sophisticated methods to attribute valueadded" (Hassel \& Terrell, 2006, p. 10).

\section{Access and Equity}

While much of the public debate has centered on the performance of charter schools, a number of scholars have also turned their attention to questions of access and equity. As noted in the initial discussion of school choice, one of the common concerns has been that increased school choice will lead to increasingly segregated schools. Thus, while charter schools hold out the promise of providing quality education for all students, the limited enrollment and the need to select students has consistently raised the specter that charter schools will in the end create a system where public funds will be used without providing equal access to all students. Concerns about skimming the top students from public schools, for example, have been voiced since the earliest years of school choice and charter school reform. Related to this question about access is a growing concern about issues of equity between charter schools and regular public schools.

Scholars are also increasingly raising questions about the lower levels of funding received by charter schools and thus in turn creating even greater inequity in low-income communities that have, ironically, embraced charter school reform as a means of increasing equity (Scott \& Holmes, 2002).

Some scholars have voiced concerns about the creation of public schools that serve increasingly targeted communities and, in turn, risk creating greater inequity in the broader society. Fuller (2000), for example, described it as "an isolationist rendition of village republicanism" (p. 28), in which local communities eagerly seek the opportunity 
to control their own schools and thus build a stronger sense of local community. The intoxicating power of local control reflects the analysis of scholars like Chubb and Moe (1990) that institutions like the state and district offices are irreparably broken. In the process of embracing community-based charter schools, however, communities risk allowing the broader society to ignore the pressing issues of structural inequality. As Fuller writes, "it denies the fact that only in a larger public square can the structural (cross-community) causes of inequality be addressed: family poverty, the hollowing out of inner cities, and resulting inequities in how schools are financed" (p. 8). Fuller is not suggesting that charter schools do not potentially have a powerful place in school reform, but he does note that they must "balance tribal cohesion with democratic discourse" (p. 236).

The research, although limited, would seem to suggest that Fuller's (2000) concern is not entirely misplaced. Several studies have found that charter schools receive less money than regular public schools (Miron \& Nelson, 2002; Slayton, 2002; Speakman, 2008). Speakman's (2008) study makes the strongest claims. Speakman (2008) shows that time and again charter schools receive less money than the regular public schools. Speakman's (2008) analysis reveals the gap is not because schools receive fewer state dollars but rather a result of local and facility funds that regular public schools receive but that are not readily available to charter schools. As she notes, "the evidence shows that the states fail to compensate fully for these disparities, even though they are the primary funders for charter schools" (p. 97). 
Scott and Holmes (2002) add to concerns about unequal funding with public dollars with an examination of the challenges charter schools face to secure additional sources of funding. They argue that charter school reform has actually magnified "preexisting inequalities across communities, and unequal access to resource-rich social networks" (p. 106). In other words, rather than creating greater access to improved education for low-income communities it has exacerbated the inequities between wealthier and poorer communities. The reason for this is the limited number of strong ties between low-income communities and sources of private funding (strong ties are connections between family and close friends), and thus the heavy reliance on weak ties to secure additional sources of revenue. While some charter schools have been successful in creating and sustaining those connections, they emphasize that chronic underfunding from public sources makes these connections not simply helpful but rather essential for charter school survival. As they write, "charter school reform is unique in that it leaves partially 'public funded' schools starved for resources to pay for fundamental things, such as buildings and equipment .... Thus, charter schools exist within a policy framework that leaves them no choice but to scramble for private resources" (p. 126).

While funding inequities have been shown to be real, the concern of social sorting or that charter schools are somehow skimming students from other public schools has for the most part proven to be unfounded. Miron and Nelson (2002) note, for example, that "figures do not provide evidence of social sorting" (p. 75), while Zimmer and Buddin (2008) conclude, “The evidence shows that charter schools have not created 'white enclaves' or skimmed high-quality students from traditional public schools" (p. 190). 
Indeed, the results, if anything, simply reinforce the concerns expressed by Fuller and others. As Zimmer and Buddin note, "In fact, charter schools have proven to be more popular among black and lower achieving students and may have actually created 'black enclaves"' (p. 190). Wells (2002) points out further that charter schools are in some cases increasing racial and social class segregation.

The increasing segregation of schools is, of course, not limited to charter schools. The Harvard Civil Rights Project has released several significant reports in the last decade that have shed light on the increasing segregation in schools. Orfield and Yun (1999) noted four major trends in schools, including the resegregation of the American South, the increasing segregation of Latino students, increasing minority enrollment in suburban schools coupled with increasing segregation within those communities, and the persistent finding that while other racial groups, including African American and Latino students, are experiencing some diversity in their schools, whites remain in “overwhelmingly white schools" (p. 3). A more narrowly tailored study was later released by Reardon and Yun (2002) that noted "segregation levels are quite high in private schools, particularly among Catholic and other religious schools" (p. 3). Their research revealed that black-white segregation is greater among private schools than among public schools, while Latino-white segregation is less among private schools than among public schools. As Reardon and Yun (2002) wrote, the reasons for segregation are not necessarily clear, but the evidence does strongly suggest that "private schools, as now operated, are not a significant answer to the problems caused by intensifying racial isolation in public schools as desegregation is abandoned" (p. 8). 
The importance of better understanding the reasons for these choices may be significant, as evidence by studies that have shown that "assessments of school quality appear to be based primarily on the race of the students enrolled" and that the "percentage of minority students enrolled in the public schools has a significant effect on the decision of white parents to enroll their children in private schools" (Levin, 1999, pp. 280-281). Godwin and Kemerer (2002) make the broader point that families who choose school choice options are different from families who do not make the choice, and that unfettered choice will lead to increased segregation on the basis of academic ability and family involvement. They also note that studies of choice suggest that it leads to some level of skimming and a slight increase in segregation by income and ethnicity, although they are quick to point out that the levels are actually lower than the effects that occur through residential choice (the decision of people to move to a different area so their child can attend a different school).

What are the takeaways for charter schools? Studies clearly show that charter schools, and other types of school choice, have not contributed significantly more than other factors such as residential choice to school segregation, but they have also not effectively resolved issues of access and equity that remain so salient, particularly within inner city schools.

\section{Charter School Governance}

As noted earlier, charter school reform is at its core a reform in the governance model. In this section, I will briefly review the governance structure in use in charter schools, with particular attention to the role of authorizers and charter school governing 
boards. While much of the charter school scholarship has focused on measuring student achievement and determining how effective charter schools have been, the real issue may be the challenges that are created by the charter school governance model and the support it offers or the impediments it can create for this type of school reform. These challenges, including fiscal sustainability and management, effective oversight of program, and maintenance of relationships with external groups, are undoubtedly most pronounced in low-income communities, revealing yet again the difficulty of creating meaningful and sustainable school reform for our most needy students.

\section{Charter School Governance Structures}

The complexity of charter school governance starts at the top of the organizational structure. The initial power rests in the hands of authorizing agents. There are several primary authorizing agents, including local district school boards, state boards of education, universities, and state chartering authorities. As Teske et al. (2005) note only somewhat tongue-in-cheek, "the practice of creating, overseeing, and renewing or closing charter schools is evolving in a typically complicated American policy environment about which much is speculated and little is really known" (p. 130). Authorizing agents are responsible for accepting applications, reviewing them, approving them, and then holding the school accountable through subsequent renewals and, if necessary, closure, if the school is not meeting expectations. Not all states have the same authorizing agents. California, for example, only allows local school boards, county boards of education, and the state board of education to authorize charters, while Minnesota has a variety of authorizing agents, including universities. As will be noted in more detail later, however, 
while California does not allow universities to serve as authorizers, there are a number of universities that have supported charter schools or served as partners in charter school ventures.

In most cases, the main governing body for each charter school is an independent board of directors. There are very few studies that have focused on charter school boards of directors, yet this group is essential in determining the success or failure of the school. Similar to a board of directors in other non-profit organizations, charter school boards represent a key part of the classic tripartite system of governing (Houle, 1997). In the simplest terms, the board of directors is "an organized group of people with the authority collectively to control and foster an institution that is usually administered by a qualified executive and staff' (Houle, 1997, p. 6). Key tenets of board operation include a recognition that the main work of the board should be spent "supporting the institution, not in controlling it" and that while the board has ultimate authority they should "exercise it as rarely as possible" (p. 7). In addition, the board is only "formally alive" when it is holding an official session. Houle (1997) also highlights other tensions inherent in board work, including the need to have a board that represents various constituencies yet board members who are focused on the collective mission not the needs of interest groups. As another example, Houle (1997) notes the oft-cited and at least partially true perception that a board can be a "group of part-time nonspecialist people who behave in idiosyncratic ways and are chosen according to no known system of merit ranking (other than, perhaps, wealth or social position)" (p. 95). In other words, Houle (1997) is emphasizing that boards hold a great deal of power yet membership is not necessarily 
based on expertise or understanding, but rather on the ability of people to help an organization raise money or the desire of someone to be on a board to raise their own social status.

Houle's (1997) exploration of governing board uncovers issues that clearly arise within the charter school realm-conflicts between boards of directors and school administrators, confusion over appropriate roles for various groups within the tripartite system, relationships with external groups such as school boards and authorizing agencies, and questions about the value of having an independent board of directors. As Houle writes, some people have argued that the board structure itself is fundamentally flawed, a concept somewhat akin to the argument made by Chubb and Moe (1990) and others against the institutional structure of schooling. The issue of a fundamental flaw in the board structure is one worth revisiting as one takes a closer look at the challenges that have arisen within charter school governance models.

Up to this point, however, the focus for most charter schools has not been on the efficacy of the charter school governance model but rather on finding ways to help the governance model function smoothly. The concepts for good governance, as presented in standard non-profit governance guidebooks (Houle, 1997; Laughlin \& Andringa, 2007), are similar to the suggestions made by charter school supporters, such as the National Association of Charter School Authorizers (NACSA). The NACSA regularly publishes issue briefs focused on creating effective founding boards for charter schools, for example, and have highlighted what the NACSA sees as the key components of successful boards: "passionate unwavering belief in the school's mission, full board 
understanding of the key charter promises, shared definition of academic excellence, a clear plan to conduct oversight of the academic program, (and) a clear plan to conduct financial oversight" (Cornell-Feist, 2007, n.p.). This particular brief also emphasized the importance of creating clear roles and responsibilities vis a vis the board, the school leader, teachers, and parents and students.

At the heart of effective charter school governance is recognizing the trade-off being made between autonomy and accountability. In return for increased autonomy, charter schools are agreeing to an increased level of accountability. Thus, as noted earlier, one of the biggest challenges facing charter school authorizers and, in turn, charter school board of directors is determining effective ways to ensure that the schools are effectively meeting their missions. Hill (2004) notes that three conditions exist within the chartering structure that promotes accountability—-"performance incentives, freedom of action, and investments in school capacity" (p. 94). He points to the Massachusetts State Board of Education, the Chicago district charter office, the Charter School Development Center in Sacramento, and the NACSA as model groups that have implemented elements of effective accountability structures, such as training staff to "monitor data and set policy direction, not create directives," using "inspectorates and self-assessment processes," and "learning to negotiate performance agreements that take account of a school's unique focus and goals without sacrificing bottom-line objective measures" (pp. 95-96). He also asserts that charter schools benefit from being accountable not only to authorizers but to other consitutent groups, including parents, staff, and private donors. Hill's (2004) optimistic assessment while perhaps not totally misplaced conflates two roles-the role 
of the school principal/founder and the role of the board of directors-vis- à-vis these other constituent groups. In addition, Hill's assessment emphasizes the importance of the authorizing agent, a role that has, like board of directors, been little studied up to this point. One of the few studies uncovered by this author, the study by Teske et al. (2005) discussed earlier, revealed that local school boards are likely to be more hostile to charter schools than other authorizers, and, more importantly, that local boards are ineffective in their ability to monitor charter schools. Teske et al. point out that the limited oversight may just as likely reflect incompetence and over-stressed school boards, as it does conscious anti-competitive activity. Thus, while Hill sees reason for hope, the limited studies on the ground suggest that the governance model presents some serious difficulties for charter school operators.

\section{Focusing In on Challenges of the Governance Model}

Clearly, one of the great promises of charter school reform was the opportunity for schools to have increased autonomy from state and district bureaucracies. The intervening years, however, have revealed that this autonomy has resulted in serious challenges in terms of governance. Wells (2002) rails against what she sees as charter school policies that do not adequately support charter school operators. In other words, she contends that the rhetoric of autonomy has not matched the reality of charter school laws. In particular, she contends, "[state policies] generally fail to support the efforts of committed educators, especially those serving the most disadvantaged students in grassroots and non-profit charter schools" (p. 3). She points to three main things "ambiguity, lack of support, and 
the complete absence of equity provisions within the charter school laws in most states" (p. 3)-as the main cause of what she foresees as yet another failed school reform effort. As noted in earlier discussions of access and equity, charter schools have been consistently underfunded in comparison with regular public schools. The underfunding stems, at least in part, from the Herculean task involved with being a charter school principal and the lack of preparation that most of these leaders received for this new role. Indeed, principals need not only to fulfill the traditional role that emphasized instructional leadership and the creation of a clear educational direction for the school, but they also must navigate the complex and sometimes contentious world of school finance, oversee the challenging process of non-profit fundraising, and ensure an effective working relationship between the school and the district. Slayton (2002) points out that it is, in the end, the "savvy and know-how_or lack, thereof —of the charter school administrators" that determines a school's funding and how it addresses key questions such as "whether a charter school pays oversight and service costs to its districts, whether a district provides a facility for its charter school or schools, and whether a charter school pays for any of the school district's additional special education costs" (p. 81). This relationship between school districts and charter schools, while not extensively studied, represents an important factor that clearly contributes to the success or failure of charter school efforts.

Wells et al. (2002) shift the focus a bit by examining the relationship from the perspective of one of the primary authorizing agents, the school district. They note the strange situation that school districts often find themselves in as they are "freeing individual schools from their own bureaucracy, while continuing to argue that that very 
bureaucracy is legitimate and necessary" (pp. 29-30). Moreover, they found that in 7 of the 10 districts they studied, charter school founders and operators brought a "strong antipublic school ideology" (p. 32). Their examination of this relationship revealed that school districts have little idea of what their role is or how they should most effectively play it. Many of their decisions were driven by concerns about liability, as districts worried that problems at a charter school could, in the end, bankrupt or financially jeopardize the district. Furthermore, efforts to create accountability typically focused on fiscal issues, not academics. As the authors note, this focus reflects the traditional strength of school districts, as they have typically been able to exercise fiscal authority but have never "been very good at holding schools accountable for academic outcomes" (p. 44).

Carnochan (2002) builds on this work by arguing that decentralization "is a complex reform strategy with different effects on different levels of government, different domains, and different constituents" (p. 58). Looking at the experiences of three charter schools, Carnochan reveals not only the complexity of the district/school relationship, but also the challenges of other types of relationships-the relationships between schools and parents, school and partnering universities, and administrators and faculty — that surface amidst these changes in governance. For example, she describes a school that developed a partnership with a non-profit organization that ultimately left one teacher feeling like she had gone "from one dictatorship to another" (p. 610). In essence, she noted, while charter schools seemed to value the autonomy over governance structures, "the data suggests that decentralized schools experienced high levels of conflict under new governance 
structures, with staff and communities often battling over who would steer the schools" (p. 70).

Hill and Lake (2008) take the argument even one step further, contending that the non-profit structure prescribed by state law has seriously inhibited the ability of charter schools to successfully reform. Mirroring the findings of Wells et al. (2002), Hill and Lake find that districts are not "prepared or eager to understand their role" (p. 116). In particular, they point out that districts are not currently organized to provide the contracting and oversight expected in their new role, as opposed to the vertical management more traditionally required in regular public schools. In order to be successful, they argue that school districts must develop several main capacities:

Organizations using third parties to do essential work must know exactly what results they need, be able to tell the difference between a provider capable of delivering results and one that is not, be able to identify problems in provider performance early enough to intervene before bad results are inevitable, work constantly to build or identify other suppliers to keep current ones under competitive pressure, and replace providers in case of low performance. (Hill \& Lake, 2008, p. 116)

Given this challenging context where districts are incapable of providing adequate support, they then decry state laws that mandate charter schools adopt a non-profit structure. They point out that the communities served by the schools often do not have people with the time or expertise needed to serve on charter school boards, and thus can be filled with activist parents or with board members who do not clearly understand "the limitations of board members or the need for clear delegation to management" (p. 121). Furthermore, they stress that traditional public school leadership training does not provide the expertise needed by charter school administrators for these positions. They argue that 
schools should be able to adopt different types of models, including sole proprietorships, partnerships, or board-governed corporations. In addition, they call for increased funding and the development of additional capacity for district offices so they can more effectively play their role vis a vis charter schools.

The common link of these different studies seems to be the limited understanding of what is really happening with charter school reforms from a governance perspective as well as a lack of consensus about the ideal structure or structures that should be considered if people are going to ensure the long-term viability of charter school reform. Indeed, these studies suggest that while people consistently describe charter schools as having increased autonomy, the serious governance challenges faced by many of these schools raises questions about how much autonomy these schools actually have. Indeed, in many cases, charter schools may simply be replacing one dysfunctional governance model with another.

\section{Relationships with Partner Organizations}

The creation of partnerships with universities, businesses, non-profit organizations, and other community institutions has represented another important link in the charter school reform movement. While charter school partnerships have also not been extensively studied, the literature surrounding partnerships in general, and university partnerships in particular, sheds additional insight into the types of challenges underlying the charter school governance model. Much like charter school reform itself, partnerships have consistently held out great promise and have been introduced with much fanfare, yet their implementation has been complex and the results have not always been positive. In 
particular, the optimism surrounding school-university partnerships has been noteworthy. The need to link higher education with K-12 education seems self-evident when the topic is raised, but the success of these ventures has been mixed.

Sanders (2006) offers a helpful conceptual framework for understanding the myriad of different partnerships that exist. Noting the types of arguments that have been traditionally been made in favor of collaboration — need for additional human and material resources, the opportunity to increase "students' social capital through their connections with students' communities" (p. 3), and the need to break down the anachronistic isolation of schools in an increasingly integrated and diverse world-she suggests that people need to recognize a continuum of partnerships. On one end, she describes simple community partnerships, which she characterizes as short term and which involve unidirectional exchange, low levels of interaction, and limited planning. On the other end of the spectrum, she describes complex partnerships, which are long term and which involve bi- or even multi-directional exchange, a high level of interaction, and extensive planning and coordination (pp. 8-9). While the latter are significantly more difficult to sustain she is quick to point out that the positive outcomes are much greater.

Sanders (2006) offers an analysis of the major obstacles identified in complex school-community partnerships. She mentions Cushing and Kohl's (1997) work which identified fear of public scrutiny, staff burnout, and teachers' and administrators' negative perceptions of students' families and communities; Mawhinney's (1994) and Epstein's (1995) works that identify territorialism; and Crowson \& Boyd's (1993) work that 
identifies "unresolved issues of information sharing, resource mingling and professional turf' (Crowson \& Boyd, p. 152). She adds her own list of obstacles, including participation, lack of time, community resources, leadership, funding, communication, and focus. While the list may seem exhaustive and perhaps exhausting to understand, she concludes by suggesting three main factors that seem to impact the overall effectiveness of school-community collaborations: "a shared vision, clearly defined roles and responsibilities, and open communication" (p. 25). These three main factors sound, perhaps not surprisingly, remarkably similar to the concepts of good governance as suggested in both the non-profit and charter school governance literature. She also notes five main components of successful community partnerships include a high-functioning school, a student-centered environment, effective partnership team, principal leadership, and external support. Most noteworthy, and perhaps most troubling, for the many proponents of partnerships is her emphasis on high-functioning schools. The notion that good schools with many resources are the most likely to benefit from partnerships, while at some level obvious, suggests that the schools that most need these partnerships because they have minimal access to resources are the very places that are least likely to be able to effectively capitalize on these opportunities.

Cordeiro and Kolek (1996) examine the intersection between school leadership and educational partnerships. In the introduction, Cordeiro and Kolek identify five key factors for successful partnerships_-leadership, trust, stability, readiness, and a common agenda. They also introduce the concept of a comprador. "A Portuguese word ... [that] literally means "buyer," Cordeiro and Kolek note that the term was used in China to 
denote people "who acted as liaisons between foreign firms and Chinese officials"" (Cheng, 1986, p. 281, cited in Cordeiro \& Kolek, 1996, p. 13). In their usage, a comprador is a person who is able to navigate across the boundaries that exist between different organizations. The need to develop the capacity of educational leaders to be "bior multi-lingual and cultural" (p. 13) is imperative if partnerships are going to develop truly reciprocal relationships and collaborative cultures.

Restine's (1996) chapter on partnerships between schools and higher education institutions provides a helpful transition between the general concept of school partnerships and the more specific concept of school-university partnerships. Restine emphasizes the possibilities school-university partnerships have for "reinventing and revitalizing education across the country" (p. 34), but also cautions about the significant cultural differences between the two types of organizations. While "universities value norms based on generalizations about schools and teaching ... schools prefer norms that have an application in a material context" (p. 36). Furthermore, she mentions Klein's (1990) list of seven predictable barriers to collaboration: "the illusion of consensus, failure to negotiate a common working vocabulary, open conflict over status, too large a group, equating mission with vision, neglecting the need for designated leadership, and failing to involve students, faculty, parents and practitioners" (p. 37). The absence of leaders, or compradors, who understand these barriers and the importance of negotiating across the different cultures can be a recipe for disaster. 


\section{School-University Partnerships}

Sirotnik and Goodlad's (1988) edited volume offers the logical starting place for analyzing school-university partnerships. The volume emphasizes the vast, yet still unrealized, potential available through school-university partnerships. Goodlad (1988), for example, notes how one of the essentials of professional renewal--the "continuous infusion of both relevant knowledge and alternative (indeed, countervailing) ideas for practice stemming from inquiry into the enterprise" (p. 11)-is often missing from schools, yet seemingly available through more effective collaboration with university partners. Despite that, he argues, "the joining of schools (and school districts) and universities in commonly purposive and mutually beneficial linkages is a virtually untried and, therefore, unstudied phenomenon" (p.12). Goodlad also notes that the promise of these partnerships is in large part due to the existence of two very different cultures. He invokes McNeill's (1986, p. 16) argument that "throughout civilization fundamental change tends to be the result of different cultures impinging on one another" (cited in Goodlad, 1988, p. 13), noting that universities and schools "differ in purpose, function, structure, clientele, reward systems, rules and regulations, ambience, ethos" (Goodlad, p. 14).

Goodlad (1988) ultimately argues for a symbiotic view of partnership —"two different kinds of organisms (institutions) are joining for the satisfaction of mutual selfinterests" (p. 23). He emphasizes that it must be both selfless and self-serving if the partnership is going to succeed. In other words, a symbiotic relationship only succeeds if both organisms have something the other wants and needs. The volume includes case 
studies of different partnerships, and then concludes with a synthesis from Sirotnik and

Goodlad that offers seven tentative and "highly speculative observations" (p. 219).

First, the role of executive director may prove to be crucial . . . Second, whatever the governance structure initially established, it will create problems and probably will require later modification .... Third, the disparity between the rhetoric of expectation and the financial commitment of school-university partnerships raises interesting questions about the future .... Fourth, questions of involvement, participation, and representation must be resolved on shared turf: the individual school, on one hand, and the university's programs for preparing educators, on the other .... . Fifth, for this time, energy, and motivation to be poured into creating parallel programs is to assure failure .... Sixth, if the necessary mechanisms are to be sensitively nurtured, the partnership must become self-conscious of the change process .... Seventh, the ultimate indicators of the success of a schooluniversity partnership are not what gets marked up on the scoreboard, however important short-term accomplishments are as motivators. The nature and quality of institutional and individual renewal serves as the source for determining evaluative indicators. (pp. 219-224)

In essence, Sirotnik and Goodlad's volume served as a clarion call for increasing schooluniversity partnerships. While recognizing the many obstacles to these partnerships and the potential for failure, they argued that the future of educational renewal is at least in part dependant on the creation and proliferation of these types of collaborative opportunities.

One of the most notable school-university partnership models that has developed in the intervening years — the Professional Development School (PDS)-offers ample evidence of both the promise and pitfalls of partnerships. Levine and Trachtman (1997) note that while antecedents can be found in things such as John Dewey's Laboratory School, the current movement owes its impetus to groups such as the Holmes Group and the National Network for Educational Renewal, the latter initiated by Goodlad (Levine \& Trachtman, p. 1). PDSs offer a prime example of Sanders' concept of complex 
partnership. Several works capture the early excitement represented in these ventures (Darling-Hammond, 1994; Levine, 1997). PDSs represent the confluence of several key concepts - the professionalization of teaching, the immense potential available from school-university partnerships, the focus on developing new models for what Sarason called the "regularities of schooling_time, space, resources, roles, and relationships" (cited in Levine \& Trachtman, p. 4), and the desire to improve schools particularly in poor, urban areas. Perhaps the most powerful recurring metaphor is the concept of creating an educational model based on the medical model; in other words, schools modeled after teaching hospitals where doctors have created a living laboratory that integrates research, practice, and training in one institution. In essence, PDS's are focused on four main goals: improvement of student learning, preparation of educators, professional development of teachers, and research and inquiry into improving practice (Teitel, 2003).

The challenges of PDSs have been evident from the beginning. Teitel (2003) provides a comprehensive review of PDSs and suggests important learning that can be applied to continuing efforts. He emphasizes two different stages-start-up challenges and challenges in sustainability. During the early stages, organizations are forced to confront both their own culture and the culture of the partnering organization and to ask whether or not the two are good partners for each other. He refers to Saphier and King's (1985) 12 norms for strong cultures, which includes collegiality, high expectations, trust and confidence, open communications, and tangible support, and emphasizes the need for both organizations to understand how the two different organizations currently operate 
and how that will impact a partnership. He emphasizes the importance of developing trust, and also cautions about the larger contextual issues - the environment in which the partnership is being formed - and the unforeseen consequences that context can have in the process of forming the partnership.

As the partnership moves out of the start-up stage, he emphasizes the importance of creating permanent changes in the governance structure that support the new partnership as well as developing a critical mass of people involved in both organizations that are engaged in the partnering process. He also points out that while the ultimate goal of PDSs is student learning, many of the challenges that are faced on a day-to-day basis are more focused on adults. As he writes, "the issues and challenges of collaboration seem to be less about students and their learning and more about the adults and how to best build relationships among them" (Teitel, 2003, p. 24).

Johnston (1997) offers one of the more interesting and thought-provoking perspectives on collaboration. Focusing on 6 years of partnership between Ohio State University and several elementary and middle schools that joined together as Educators for Collaborative Change, the book is a series of essays edited by Johnston. The authors adopt a post-modern lens to deconstruct the complex relationships that evolved between the different individuals and institutions. They argue that their most profound learning involved the recognition that the tensions that exist between schools and universities rather than representing points of conflict needing to be resolved "are instead to be cherished as potential sites for learning and growth" (p. 12). They continue, "When there were differences, we had to reflect, compare, and adjust our thinking in light of someone 
else's perspective. When our differences exist in this kind of productive tension, learning is most likely to occur" (p. 13).

The challenge in this is immediately evident, as the process they describe requires extensive conversations and time for reflection. Clearly, not everyone was as eager as Johnston and some of the others to engage in this type of exercise, as they note that some people became frustrated by the focus on conversation at what they perceived to be the cost of action. "All this talk about tensions is driving me crazy-tensions, tensions, tensions. Meanwhile, things at my school are falling apart. There must be a better way to talk about what's going on in this PDS" (Johnston, 1997, p. 19). This process also surfaced the significant cultural differences between the two institutions. As Johnston (1997) writes:

We have come to appreciate the striking differences between schools and universities with respect to asserting disagreements. Many teachers feel that their schools are not safe places to disagree. If you object to something or disagree with a colleague, you are considered uncooperative or aggressive. At the university, it is expected that you will offer your ideas and heartily debate issues. Professors, much more than teachers, are rewarded for idiosyncratic ideas, and personal opinions are expected. (p. 39)

The process also raises questions of privilege and priority. The collaborative process employed by the PDS reflected a differing sense of time.

Time is a variable of privilege. If the collaborative process takes an excessive amount of time (which it almost always does), then it tips the balance in favor of those who have the privilege of not being in a hurry. Urgency is important . . . . The urgency that different individuals bring to the table impacts on their ability to give and take in a collaborative process. Because it's our house that's on fire, I don't want to spend two or three hours talking about an issue . . . . I want to put out the fire! (Johnston, 1997, pp. 86-87) 
Cramer, a principal at one of the schools, reflects a similar sensibility as he notes that his job security is dependent on results. While he suggests that he appreciates a collaborative culture, he also notes that the principal ultimately owns the issues if the school is having problems.

\section{Conclusion}

This quick review of the partnership literature reveals an interesting synergy between the challenges facing partnerships and the challenges facing many charter schools, particularly in the area of governance. While partnerships and the chartering process seem to offer great promise for school reform, both have foundered on the complex realities inherent in their implementation. Interestingly, although university partnerships have been quite common in the charter school movement, no one has yet examined in detail the particular challenges a charter school partnered with a university creates. Clearly, the potential to bridge the gap between theory and practice is ripe within these types of partnerships, as is the chance to bring the significant resources of a university to bear on traditionally under-resourced communities. At the same time, the challenges uncovered in previous studies-for example, the difficulties of collaboration and the complex governance structure of charter schools-suggest that university/charter school partnerships will inevitably encounter difficulties. Undoubtedly, creating these partnerships without understanding the complexity involved is a recipe for disaster.

More broadly, the preceding review of the literature on school choice, charter schools, and partnerships uncovers an important and as yet understudied element of the charter school reform movement. The existing charter school literature has tended to 
gloss over the challenges on the ground facing charter schools as they are founded and then developed. In particular, while the literature foreshadows the types of challenges faced by low-income conversion charter schools, such as SDMS, no study has effectively examined the central role that the governance structure plays in this scenario. Conflicts over roles and relationships, battles for resources both from the district and outside funders, and the cultural clashes that surface with the creation of much-needed but little understood university partnerships all pivot around the role of the charter school board of directors. Given significant authority, yet also undercut at every turn by authorizers and other constituent groups, the charter school board of directors represents a central and as yet little studied component of the charter school reform movement. 


\section{CHAPTER 3}

\section{RESEARCH METHODOLOGY}

The dissertation is a case study of a southern California conversion charter school board of directors. The study meets Stake's definition of an instrumental case study, or as he writes, "the case is examined mainly to provide insight into an issue or to redraw generalizations" (Stake, 2005, p. 445). As Yin (2003) notes, case studies are most effectively utilized when "a 'how' or 'why' question is being asked about a contemporary series of events, over which the investigator has little or no control" (p. 9), all conditions clearly met in this study. A careful examination of the operations of a conversion charter school board of directors offered important insight into the governance issues facing these types of schools.

Grounded theory methodology helped to shape the study. As Charmaz (2005) writes, "Grounded theory methods consist of simultaneous data collection and analysis, with each informing and focusing the other throughout the research process" (p. 508). There were three main parts to the research process:

- Attendance at board of directors meetings from February 2008-June 2009. These meetings provided the initial data used to generate the codes and categories that would become the focus for later steps in the research process. In addition, observation of these meetings allowed an understanding of the public operation63s of the board of directors and introduced new codes and categories as they arose over the course of the research period. 
- Interviews with members of the board of directors as well as other key people connected to the community. The interviews were started in January 2009 and were completed in June 2009. An effort was made to interview all members of the board of directors, with the exception of two board members who are part of this researcher's dissertation committee. Other individuals who were identified through their role at board of directors meetings or who were identified in interviews as key people in the school's governance were also contacted and, if possible, interviewed.

- Document collection and analysis. Agendas and additional materials from all board meetings were collected. In addition, key documents that were referenced during meetings - the strategic plan, the proposed memorandum of understanding with the district, the initial charter-were also collected. Consistent with grounded theory, I approached the process without strong preconceptions of what I would find yet also conscious of needing to conduct the study systematically and thoughtfully. Thus, I took steps that forced me to revisit each type of data - board meeting transcripts, interview transcripts, and documents —at several different times during the process and in several different ways. As Dey (2007) notes, this "constant comparative method" is essential to counter "the dangers of preconceptions" and to safeguard against "our predisposition to see patterns and order where there is none" (p. 175). In addition, the process was iterative; while the following section divides each stage into distinct categories, it is important to recognize that each step informed the other steps along the way. As an example, the code for "administrative structure" did not 
clearly emerge until spring 2009 when the board of directors began to publicly discuss structural shifts at the school. The broader category, however, "executive leadership" and other codes, including "role of the principal" and "relationship with board of directors" had clearly emerged as early as June 2008.

I want to add a quick note on terminology. My definition for the terms code and category are derived from Bryant and Charmaz (2007) who suggest, "It would seem that the best working model places these terms in a hierarchy from bottom to top: respectively code, category, concept" (p. 18). Thus, codes represent the most specific analytical lens and are often descriptive. For example, the code "relationship between the school and the district" quickly emerged at early meetings as issues were discussed involving the school district. Along the way, a more general category_-"board of director relationships"emerged which subsumed codes including the school district code.

\section{Board of Directors Meetings}

Initiated during the 2008-2009 school year, the study of the board of directors was part of a broader research study being done by this researcher's university. Consistent with grounded theory methodology, I did not enter the study with a clear hypothesis or with specific preconceptions about the issues connected to a charter school board of directors. The original decision to regularly attend the meetings was done in consultation with one of the lead researchers with the strong sense that understanding the operations of the board of directors would prove helpful for better understanding charter schools in general. The study's timing was random and had no connection with specific issues or topics that were or were not likely to arise at the board of directors meetings. 
Monthly meetings are open to the public. During the 16-month period, I attended 14 board meetings (see Appendix A for complete list). At all meetings, I observed as a member of the audience. While there are small windows of opportunity for participation from the audience, I did not participate in any way during the meetings. I audio-taped all meetings and I also typed detailed minutes as I listened and observed. Near the conclusion of the 16-month period, I re-listened to each meeting and added detail to the minutes I had initially transcribed. The systematic analysis of board meetings can be divided into several stages--focus for early research, creation of interview guide, and reexamination for findings.

\section{Focus for Early Research}

During the course of board of directors meetings in spring 2008, I was able to generate codes and categories that would provide a focus for additional research by paying attention to the issues that arose at meetings. By listening at the meetings and paying attention to the agenda items, I was able to quickly generate a preliminary list of categories and codes. For example, the category of "financial management" became readily apparent through board discussion, as well as the sub-codes of the role of a "memorandum of understanding" with the school district and the issue of the "SELPA." With the turmoil in June 2008 surrounding the executive director, the codes "relationship between the board and the executive director" and "the role of the executive director" emerged. In addition, the turmoil throughout the subsequent months revealed real questions about "the role of the board of directors," both in terms of the perception of the 
board members themselves and members of the broader community, including parents and teachers.

During summer 2008, I immersed myself in the research literature of charter schools, partnerships, and non-profit governance. The initial codes and categories generated during the spring helped to focus the literature review. In particular, the decision to examine partnership literature emerged from the issues surrounding the partnership between the charter school and the university. In addition, I looked for literature connected to charter school fiscal management, as well as research on the role of the executive director or principal in a charter school.

\section{Creation of Interview Guide}

In January 2009, following attendance at nearly one year's worth of meetings and after spending extensive time reviewing relevant literature, I created an interview guide. The interview guide was structured around codes and categories that had emerged from the board meetings and that had emerged from the literature. A more detailed explanation of the guide will be provided in the section on interviews.

\section{Reexamination for Findings}

During the final data analysis stage of the dissertation, I re-listened to each audiotaped session of the board of directors meetings while simultaneously reviewing and adding detail to the notes I had taken during meetings. Following this process, I then carefully coded each meeting transcript using Microsoft Word track changes. First, I coded for the codes identified in the early stages of the research-relationship with the school district, for example. 
Finally, I revisited the transcript one more time with an eye toward topics or issues that may have been silenced or that may not have been recognized explicitly by the participants. While not always obvious, I looked for instances in which issues were raised and then ignored, or in which comments were made suggesting a particular mindset that may not have been evident to the participants themselves. In particular, I was conscious of the potential presence of a "deficit model" of the community, given some of the research that had emerged during the preceding year as well as comments made during interviews.

\section{Interviews}

Interviews offered additional insights into the issues that were raised during the board meetings as well as more detailed information about specific topics. The interviews offered insight into the less public elements of the board of directors' job, although the study did not involve the examination or analysis of confidential materials or issues. Starting in January 2009, I began interviewing members of the board of directors as well as other individuals who had been identified as key players in the operations of the board of directors. Between February 2008 and June 2009, 14 people served on the board of directors, with 11 members on the board of directors at the conclusion of the study in June 2009, although only 6 of those members were signed up to return for the 2010-2011 school year. In the end, I interviewed 15 people, including 9 members of the board of directors, one school administrator, the school's liaison with ExEd (an educational management organization that provides financial services for a number of charter schools in southern California), two members of the San Diego Unified School District (SDUSD) 
Office of School Choice, and a representative from the California Charter School Association (CCSA). I did not interview two members of the board of directors because they were members of my dissertation committee. In addition, two of the three faculty representatives to the board declined repeated interview requests. I interviewed the founding executive director in February 2007 as part of an initial study that led to this research, but she declined repeated requests to be interviewed in spring 2009 and thus I was not able to conduct an interview with her during the 16-month period of this study. In addition, the interim executive director, while not offering an outright rejection to my numerous requests, never had adequate time to meet for an interview. I will return to this issue in the limitations section.

Interviews ranged from 30 minutes to 90 minutes, although most lasted 60-75 minutes. All of the interviews, except for two, were taped and fully transcribed. One of the exceptions was a phone interview with a board member, in which I did not have the technology to tape the conversation. I did, however, attempt to transcribe on my computer as closely as possible the conversation as we talked. The second interview was with the representative from the CCSA. I did not tape this, as it was primarily an informational interview about charter schools in general. While she had passing knowledge of the school, she did not have adequate knowledge to justify inclusion alongside the other interview transcripts.

An interview guide was utilized for all interviews. The guide was initially written for the members of the board of directors, thus minor modifications were made when speaking with individuals who were not directly involved with the operations of the 
school, such as the members of the SDUSD Office of School Choice. In those cases, the key issues were still addressed but certain topics - such as the history of the school-were not broached as the individuals did not have any knowledge or expertise about that area. Appendix B provides a detailed analysis of the interview guide and the rationale for why each question was used. In broad terms, the interview guide was created from codes and categories that had emerged through attendance at the board meetings and also through the literature. The interview guide was utilized to ensure that I asked about key areas and to allow for consistency when I returned to analyze the interviews. I did not religiously adhere to the interview guide, although it did provide a clear framework for each conversation.

Interview transcripts were initially coded using the codes that had been generated through the analysis of the board meetings and the literature. Following this step, transcripts were reanalyzed with an eye toward finding codes that may not have been evident at first glance. Similar to the process used for analyzing board meetings, I looked for issues that may have been lingering under the surface.

\section{Document Collection}

These data were supplemented by the collection of official materials from the meetings, including minutes, agendas, and other supplementary items. In addition, historical materials were also gathered, such as the school's original charter, articles in the local newspaper chronicling the school's early years, and the school's 2007 Strategic Plan. I used these documents throughout the analysis and writing process, as they offered evidence and clarification for issues that arose during board meetings and interviews. For 
example, a question arose about the terms of the original partnership agreement between the university and the school. Reviewing the original charter documents, I was able to find the initial partnership agreement, thus helping to clarify the formal conditions. I also did some analysis of the documents. For example, I reviewed board agendas and executive director reports with an eye toward better understanding the meeting structure and the patterns that emerged over the 16-month period.

\section{Data Analysis}

As noted above, coding was systematically applied for each research area. In addition, a level of triangulation occurred throughout the study, as the different research areas continually informed the steps taken in other areas (Glesne, 2006). For example, the board meetings provided the basic research which was then developed through the interview and document collection process. At the same time, the timing of the interviews allowed me to consider new insights at future board meetings and during the analysis stage.

In the early stages of writing the dissertation, several categories continually emerged in interviews and board meetings - fiduciary governance (accountability, fiscal management, facilities management, etc), roles and relationships (of board, partnership, faculty, school district), and communication (transparency of, confidentiality surrounding). Examination — and reexamination—of these categories suggested the presence of an underlying analytical framework. The framework focused on three tensions that inhere in the charter school governance structure-governance $v$ management, transparency $v$ confidentiality, and representation $v$ trusteeship. Discovery 
of the framework helped to structure the findings chapter and helped to bring together what had seemed at times to be disparate and discrete analysis. Following recognition of this framework, I was able to revisit the data once again with an eye toward locating the different codes and categories within this framework. New insights also emerged. My ultimate ability to cohere much of the data within the framework helped to reaffirm its analytical power.

\section{Significance}

The proposed study provides an important lens by which to examine the charter school reform effort, namely the role of a charter school board of directors. The central promise of charter school reform has been the ability for a school to have increased autonomy while being adequately held accountable as a publicly funded school. To date, few studies have carefully examined how this promise plays out in practice. In addition, NCLB-mandated conversion charter schools represent an understudied subset within the charter school world, as they represent a novel approach to addressing traditionally underperforming schools.

While it would be difficult to argue that the findings from this study are generalizeable to all charter schools, they can provide a framework by which to examine other charter schools and the viability of the charter school reform effort (Donmoyer, 1990). The challenges of charter school governance-lack of financing, inadequate facilities, conflicts with key external groups including school districts-would assumably be exacerbated in a NCLB-mandated conversion charter school, thus making the role of the board of directors even more significant. 


\section{Limitations}

Recognition of my own subjectivity, as well as that of some of the research participants, is important as I venture into this study (Peshkin, 1988). SDMS is intimately connected with the university where I am a graduate student, thus there is a natural inclination on my part to treat the school and its development favorably. In addition, I am closely connected to many members of SDMS's board of directors, as they are the leaders of the research team of which I am a part and they are also connected to the university. Indeed, one of the interview subjects is the dean of my graduate school program. Beyond the personal connections, I am also aware of my own predisposition as a private school educator to view charter schools favorably. I recognize my belief that charter schools represent a positive development amidst the often dispiriting world of urban educational reform, in particular as they benefit from at least some of the advantages I experience in my own educational climate. In addition, I know that my commitment to educational equity, my desire to see private schools become increasingly inclusive, and the admission of a few SDMS graduates into the school where I work predisposes me to the image of SDMS as a success story.

Despite all this, I feel confident that my particular research focus and the proposed research design ensure as much as possible that the analysis will effectively reflect the data that are collected. As with all researchers, I enter this study with my own subjectivity (Peshkin, 1988). With careful attention to these biases, as well as a research design that ensures triangulation of data (interviews, documents, and observations) I am confident 
that I will be able to provide an analysis that will shed helpful light on this important topic. 


\section{CHAPTER 4}

\section{FINDINGS}

The past 16 months at SDMS have been quite tumultuous for the board of directors. While the opening meeting in February 2008 offered little indication of the major issues that would arise, hints of impending trouble surfaced as early as March 2008 and by the fall the board and the school were in turmoil. As noted earlier, the time period for this study was randomly selected, yet the ensuing difficulties and their tentative resolutions provided a rich period for analysis. A number of significant events and decisions were made during this time, and the role of board governance, which sometimes remains invisible within communities, was at moments during this period vividly brought to the forefront. In the end, this period provided a fascinating window into the role of board governance in the operation of a conversion charter school.

One means of understanding the period is through the analysis of three underlying tensions that inhere in the charter school board structure-management versus governance, transparency versus confidentiality, and representation versus trusteeship. Management versus governance refers to the classic dance between a board of directors and an executive director for what is the appropriate role for each group in ensuring the organization's long-term success. Carver (2006) envisions a board and an executive director on opposite sides of a clearly delineated line, with the board responsible for policymaking (i.e., governance) and the executive director for implementation (i.e., management). On the other hand, Chait et al. (2005) describe a slightly more nuanced model, with three modes of operation for a board — fiduciary, strategic, and generative. 
Within this framework, the board and the executive director work much more collaboratively to address significant issues of governance. Again, there is an underlying expectation that the board is not heavily involved in management, although the lines between what is governance and what is management are at least somewhat more fluid. Ultimately, an effective board must openly wrestle with this question and have a clear sense of the decisions it is making vis a vis governance or management.

The second tension boards face is between transparency and confidentiality. The responsibilities of a board of directors sometimes require discretion-the discussion of personnel matters, for example. In addition, effective discussion of some issues - expansion or removal of a program, for example - may require a focus on the long-term and a consideration of issues that are initially difficult to effectively discuss in an open forum. While open conversation is ultimately important, an inability to have some level of private conversation may inhibit a board of directors' ability to function. On the other hand, a successful board of directors must ensure adequate transparency to reassure members of the community that the board is pursuing the best interests of the broader community. Too many decisions made in private without any public understanding or input will lead to a lack of trust and a perception that the board of directors is not doing what is best for the organization. While traditional non-profits conduct most of their board work in private, public schools are required to conduct their business in public. The hybrid model of a California charter school—neither truly a nonprofit nor truly a public school—operates within a tension between the legal obligations 
to conduct business in public as mandated by the Brown Act and the benefits of being able to conduct some conversations in private.

Trusteeship versus representation refers to the tension over what are the expected roles for charter school board members. Trusteeship refers to the traditional role expected for board members in a non-profit organization. As trustees, board members are charged with holding the organization in trust and ensuring its long-term success and sustainability. Board members, acting within the trusteeship framework, are expected to adopt a long-term perspective and not become embroiled in day-to-day issues or shortterm concerns that can distract from the organization's long-term needs. Representation, on the other hand, reflects the traditional public school board model. Elected to their positions, public school board members represent distinct interests and their decisions often reflect current political tensions or issues. Again, the charter school model-which is somewhere between a non-profit and a public school board model-lends itself to confusion over the expectations for board members and raises questions about whether board members should lean in one direction or the other.

Utilizing these three tensions as a framework, an analysis of the period suggests four major findings:

- During the early period (February 2008-June 2008), the board focused on governance and tended toward the more traditional non-profit model of trusteeship. While relatively successful, simmering tensions were evident surrounding the role of the board in the day-to-day operations of the school. 
- During the tumultuous period (July 2008-December 2008), a failed search for a replacement and growing distrust of the partnership subsumed all other conversations. Tension around confidentiality versus transparency overwhelmed normal board operations.

- During the troubled peace (January 2009-June 2009), the board veered heavily toward transparency and, in some ways, abdicated its governance responsibilities under community pressure. The representation versus trusteeship tension came to the forefront as the board moved in a new direction and seemed to be veering toward a public school board-style and away from a non-profit model. During this period, the partnership between the university and the school dissolved, signaling a shift in the school's future direction.

- A lack of strong executive leadership throughout the period and a lack of strong board leadership during the second two periods (June 2008-July 2009) created significant challenges for the school, particularly in terms of determining the appropriate role of the board vis-à-vis the executive director and appropriate levels of communication about difficult issues.

The chapter will be divided into three sections reflecting three periods that occurred during the study. While these tensions are clearly not limited to these periods, each period lends itself to a greater focus on one of the three analytical lenses.

During the first period (February 2008-June 2008), what I would term "Normal Operations," the school seemed to be functioning relatively effectively. However, the 
emerging conflict surrounding the role of the university/school partnership illustrates the governance versus management tension that is so often at the heart of board operations. During the next period (Late June 2008-December 2008), what I would term

"Tumultuous Times," the school experienced a dramatic upheaval, precipitated by the resignation of the executive director in late June. The subsequent search for a replacement was badly mishandled by the board and by the end of the period faculty and even some parents were up in arms, calling for the dissolution of the university partnership and expressing serious concern with the board's decision not to hire the interim executive director. The board's struggles come into focus when viewed through the confidentiality versus transparency tension. During the final period (January 2009-June 2009), what I would term "A Troubled Peace," the board stepped back significantly and allowed the interim executive director to assume the role as the permanent replacement. The period ended with the dissolution of the university partnership, the resignation of a significant majority of the board at least partially related to that dissolution, and serious questions about the school's long-term sustainability. At the same time, glimmers of hope existed, with the beginning of a strategic planning process and a perception of growing community engagement and involvement. Events of the period highlight the tension between representation and trusteeship.

\section{Period 1: Normal Operations}

Events during the so-called period of "normal operations" provide an excellent means of understanding the roles played by the board of directors, particularly when contrasted with the later periods during which the normal functions of a board were 
heavily subsumed beneath crisis management. An examination of this period shows the board heavily focused in areas of traditional non-profit governance-fiscal and facilities management, holding the organization and the executive director accountable, and negotiations with the outside groups such as the school district. The board's rare ventures into more contested terrain-the role of university research at the school, for examplehighlights a classic management versus governance tension, as the board finds itself trying to navigate its role vis-à-vis the appropriate role of the executive director and faculty. The ensuing conflict also reveals deeper leadership concerns that would become even more apparent later during the research period.

\section{Management Versus Governance}

As noted earlier, the tension between management and governance is a common conflict between boards and executive directors. During this early period, board operations seemed to be heavily focused in the areas of governance, and there were only limited examples of situations in which the board moved into what could be perceived as management roles. An analysis of these contested situations, such as determining the role of university research at the school, reveals a classic management versus governance tension. In order to better understand the distinctions in these roles, however, I want to start by viewing examples of the board's broader work during this period. These examples fit squarely in the fiduciary mode (a typical governance function) as described by Chait et al. (2005). The fiduciary mode ensures that the school remains "faithful to mission, accountable for performance, compliant with relevant laws and regulations" (pp. 7-8). This mode emphasizes accountability and oversight, and includes financial and 
legal support and oversight, management of the executive director, monitoring of the academic program, and management of relationships with key internal (faculty, parents) and external (district office, partner university, funders) groups.

Given the operational nature of many of these issues (facilities oversight, for example), organizations often find the lines between governance and management blurred when in the fiduciary mode. Yet, during the early period, the majority of board activities did not generate controversy. In large part, this reflected two related realities. First, the bulk of the board's work was in areas that were clearly not strengths of the executive director or other members of the school administration. The school administration had no problem ceding these issues to more experienced individuals, particularly given the heavy workload the administration was shouldering. Second, the work did not significantly engage the board in the operations of the educational program, thus the board was not potentially stepping on toes or questioning the expertise of the administration and faculty. Forays into this contested terrain - in the guise of research, for example-generated a more expected defensive reaction from the administration. A closer examination of the board's work will shed further light on the issue.

\section{Fiscal and Facilities Oversight}

The best example of effective and non-contested fiduciary work can be seen in the board's handling of fiscal and facilities oversight. SDMS contracted with a non-profit educational management organization to conduct its financial management. The board's finance committee worked with the EMO representative to track and monitor the board's financial situation, and to ensure that the school remained financially solvent. The chair 
of the finance committee seemed to take his responsibility extremely seriously, and he consistently stressed that the school's financial policies were exceedingly conservative and that the school carefully tracked every penny it spent. The representative from the EMO contrasted the financial management of SDMS's board with that of other charter schools, noting:

SDMS was the last school to pay their fees, because we were making sure they were right. We were the last people to sign off on the facility use agreement until we all agreed it was fair. They are used to SDMS. SDMS set the tone of being tough negotiators from the get go and we have earned a certain level of respect that will help us in a lot of ways. (EMO representative, interview, January 2009)

The board regularly received financial updates at meetings, although they generated almost no conversation. Despite that, every indication was that the school was fiscally sound and that the finance committee was a real strength of the board.

One of the key factors that explain the school's successful fiscal management was connections between board members and members of the SDUSD Central Office. Several board members had long-standing political connections in the community, connections they could call upon in their role as board members. The EMO representative noted, "A lot of these guys already have relationships, they helped these people get elected. So it is almost like I need you, I need you to be here, and it has paid off big for SDMS" (EMO representative, interview, January 2009). Board connections with the district were particularly important because one of the largest issues that the school faced during the year were their efforts to resolve ongoing disagreements about school district charges for special education services. At the heart of the conflict was the lack of a memorandum of understanding (MOU) between the school district and charter schools, something that was 
being negotiated during the 2007-2008 school year and that was finally approved by a number of charter schools during the 2008-2009 school year. Without this MOU, the school and the district found themselves constantly battling over two fees-special day fees, which are fees charged by the district to provide services for students who are not mainstreamed, and an encroachment fee, which are fees charged per student to cover general special education services provided by the district.

SDMS did not deny that it owed the special day fee, but it demanded clearer accounting for the amount it was being charged. This was the crux of the battle described at the March board meeting when the chair of the finance committee noted that the school had not and would not "blink" when dealing with the district. More importantly, the school's ability to delay payment of this fee reflected its commitment to fiscal discipline. Ultimately, the school seemingly won this battle, as it was able to delay final payment until June 2008 and, in the end, the school district agreed to the school's contention that the fee was $\$ 10,000$ too high and the school district forgave this portion of the payment. During conversations about this fee in March, one of the board members made it very clear that he was not afraid to make this a political issue.

Send correspondence to the department head but cc everyone on that board, including the new superintendent, because we have to hold them accountable. This is an election year, by the way. Never forget that. My old activism senses are kicking back in. (transcript of board meeting, March 3, 2008)

As for the encroachment fees, the charter school was part of the school district's SELPA (special education legal plan area), since it was not in a position to provide its own special education services. As a member of the SELPA, a charter school essentially 
contracts with the district to have it provide special education services. This was not unique to SDMS, but reflected the reality of most charter schools that are not in a position to provide these types of expensive services. As part of the SELPA, it had no choice but to pay the encroachment fee, but SDMS was increasingly alarmed by the yearly increases in the fee. According to the notes in the February 2008 executive director's report, the encroachment fee had increased from $\$ 365$ per student in $2003-2004$ to $\$ 657$ per student in 2007-2008. More importantly, the projected fee for 2008-2009 was $\$ 722$. This fee, a per student charge, effectively cost the school nearly $\$ 350,000$ per year.

The school spent the first part of the 2008-2009 school year, along with a group of other San Diego charter schools, seeking out an alternative SELPA. Ultimately, the SDMS board of directors voted in February 2009 to remain in the school district SELPA because it would be less expensive, but the board's willingness to do the research suggested it was serious about maintaining fiscal discipline and that it was not afraid to go outside of the normal avenues to seek a solution.

Another key issue for the school and the board was the maintenance and preservation of its facilities. Similar to the SELPA negotiations, this issue was firmly located in the realm of governance, not management, and did not generate conflict between the administration and the board. Like the SELPA negotiations, however, exploration of how the board handled this issue helps to differentiate this from the management-related issues that generated more controversy.

A 2006 study commissioned by the Low Income Investment Fund highlighted the complexity of this process for California charter schools (Smith \& Wells, 2006). The 
study suggested the importance of having people with significant real estate expertise, something which was not true of this particular board. Despite that, the school seemed to be relatively effective in its ability to navigate this potential morass. Each year the school had to contract with the district for use of the facilities, a process which was never pro forma. Prior to the research period, for example, the district had tried to force SDMS to share its facilities with an elementary school, a battle which SDMS won. Facilities usage has been a hot-button issue in San Diego, and throughout California, in recent years, with charter schools increasingly willing to sue the district in order to bring it into compliance with Proposition 39, a voter-approved measure from 2000 requiring school districts to treat charter school students and district students equally (Farland, 2005). According to a policy brief from the California School Board Association in 2005, the legislation requires that "school district-provided facilities are to be reasonably equivalent to those of other public schools in the district and are to be contiguous" (Farland, 2005, p. 1). In 2006, the California Charter School Association brought a lawsuit against the district in order to force it into compliance with Proposition 39, a lawsuit that was dismissed by a trial court and then dropped by the CCSA. Each year, charter schools must submit a Proposition 39 request to the district in order to receive facilities. In February 2008, the SDMS executive director noted that the school had received a preliminary offer from the school district for the 2008-2009 school year. Over the spring, the executive director reported each month on the progress, noting in May that the school had signed a facilities agreement with the district, although the agreement included a clause that allowed the school to continue contesting the adequacy of the facilities. While there was never a 
formal effort to seek out new facilities during the 16-month period, the comment was consistently made at board meetings that the school's facilities were inadequate. In particular, people noted that the school was an elementary school site that was now being used to house a middle school.

\section{Relationship with District}

A combative spirit was always close to the surface when board members and the executive director discussed the school's relationship to the district. This was not unique to SDMS; indeed, a report commissioned by the California Charter School Association in November 2008 noted that the relationship between charter schools and the district had soured noticeably during the tenure of Superintendent Carl Cohn which had ended in December 2007 (Flanagan, 2008). The report highlighted many of the issues that appeared at SDMS board meetings during the research period, including concerns over SELPA fees, inadequate facilities, and the lack of an MOU.

Comments during board meetings, such as the one noted earlier, suggested that SDMS was always ready for a fight, if necessary. There was a strong sense that under Superintendent Cohn the school district was actively trying to sabotage charter schools. SDMS board members saw evidence of this in the decision to create a series of K-8 schools in the SDMS area, for example, which was seen as a clear threat to SDMS enrollment. Yet, interviews with board members and with representatives from district office suggest that a positive working relationship between the school district and SDMS existed throughout most of this period. Moreover, the arrival of a new superintendent in February 2008 and the subsequent report by the CCSA suggest that charter school 
representatives in general sensed a change in tone with the departure of Superintendent Cohn.

The finance committee chair perhaps best captured the school's general approach to negotiations with the district and its general perception of the relationship.

We were very measured in dealing in all the subjects that you just mentioned (SELPA, facilities, MOU). The school district had a lot of respect for us because they knew we took our fiduciary responsibility very seriously and we didn't just always sign whatever they sent. I would send some things back ... or negotiate, they would send a bill and I would split out the payment . . . . And I think we do that enough for somebody they really are going to gain respect. They are going to stop trying to screw you all the time and that's what happens, and that's why those issues - they didn't get us in trouble. They didn't raise to the level of causing any kind of abuses .... We had a very good fiscal culture where we took the business side of the school very, very serious. (Finance Committee Chair, interview, April 9, 2009)

Thus, the school was always prepared to fight, if necessary, to ensure that SDMS was treated fairly by the district. This spirit, coupled with political connections, seemed to ensure the school relatively smooth sailing during this period. In each of these situations, the board played a clear governance role, relying on its expertise and political connections to support the school's efforts in difficult negotiations. Moreover, these areas were clearly outside the realm of expertise of the administration, thus leading to no conflict between the administration and the board. On the contrary, the board's activities during these issues were clearly welcomed and reflected the board's most obvious successes during this period.

\section{Accountability}

A more complex analysis is involved with the board's role vis-à-vis accountability. While accountability falls squarely into the fiduciary mode, the challenge 
of finding effective ways to hold a school accountable is always difficult (Hill \& Lake, 2008). Unlike fiscal management, for example, accountability requires an executive director to pull back the curtain on the educational operations of the school. The ensuing conversation offers a complex dance in the best of situations, as the board needs to understand what is happening and what the executive director and administration are doing without trying to micromanage the situation. At SDMS this situation proved particularly challenging for some of the board members, who brought a great deal of educational expertise. This educational expertise could undoubtedly inform the conversation, yet it was not clear to what level the board was expected —or shouldengage in these conversations. In the end, the executive director carefully crafted conversations that focused on the least academic areas of school accountabilitydiscipline and attendance - and created an appearance of accountability without every really engaging the board in meaningful conversations that might lead to improvements in instructional practice.

At each meeting, board members were provided an executive director's report which included statistics about average daily attendance (ADA) and discipline. Explanations were often provided to explain significant increases or decreases. The sharing of discipline statistics generated several conversations about how dramatically the school culture had shifted since its conversion, a theme which reappeared consistently at the board level and was clearly a source of pride for the administration and the board. Month-to-month analysis of statistics revealed that SDMS was a safe school, with only minimal discipline problems, a far cry from the out-of-control school that several board 
members and administrators described before the conversion. The most vivid descriptions came from the founding executive director. Describing her first visit to the school in an interview, the principal recounted:

I came back from vacation and we drove out here, my husband and I, early on a Sunday morning in early August by 9 o'clock in the morning we were here. There wasn't one stitch of green out here. Everything was dead. The weeds were six feet tall. It looked like a prison. It looked hideous, and I thought, "What in the world is going on?" (SDMS Principal, interview, November 8, 2007)

Later in the interview she noted, "It was totally a campus of chaos, kids just everywhere. The adults were clearly not in charge." On the NewsHour, in nearly identical language, she explained, “My first day here, I thought, 'Oh, my goodness, what am I in for?' At any point in time, I would see 20 to 100 students just roaming the campus, many stories of setting fires in the bathrooms, destroying property, a campus of chaos" (Merrow, 2007). The founding board chair confirmed the transformation from chaos to control. She noted that another member of the board of directors, a police officer for the city schools, consistently reminded the other members about how much people's perceptions about SDMS had changed. "He always reminds us how word is out in the community, you're not going to find the police at SDMS, and if they are there it's because of something that happened down the street, and they are trying to protect the school from it" (Founding Board Chair, interview, November 16, 2007). One of the parent board members, who was intimately connected to the community, consistently reminded people that the school was located in the middle of eight gangs, highlighting how important it was for the school to remain vigilant in creating a safe environment. 
Academic conversations were less common and, as the student achievement storyline was less celebratory, the results of the conversations were a bit more complex. Several times during the 16-month period the board explicitly discussed the performance of low-performing students. The conversations typically revolved around the school's efforts to create remedial programs, such as a Bridge to Success Saturday academy. The academy was first described to the board with a bit of fanfare in March 2008, as the executive director explained that the program was focused on 80 students, including 20 students who were really at risk as they had two or more Fs in content areas. The teacher representative to the board added, "Quarter after seven last Saturday the students were already lining up, ready to go, in uniform, and it was raining .... They really are enthusiastic so far, and they are here because they are motivated" (transcript of board meeting, March 3, 2008). The report in June 2008 was less positive, as the executive director and the teacher representative to the board shared frustration with dwindling attendance over the 8-week session, noting that in the end only 45 of the students attended regularly. Despite that, the teacher noted, "The kids that came saw some real growth. A couple of boys have made a dramatic turnaround, which was nice to see" (transcript of board meeting, June 2, 2008). One of the board members raised the question at the June meeting of the role of parents in this equation. He asked, "Where are the parents with these kids? Are they part of the problem?" (transcript of board meeting, June 2, 2008). A brief discussion ensued of the possibility of charging a nominal fee for the Saturday academy and of including a parent portion to the day, thus encouraging parents to stay and be more engaged in their children's education. 
A year later, the conversation suggested that the school had not made significant strides in addressing this area, nor had the board done much to hold the school accountable. In the intervening months, the school had for the first time seen its adequate yearly progress score (AYP) fall, something which had been reported with much distress at the October 2008 board meeting. According to the California Department of Education (n.d.), the AYP is "A statewide accountability system mandated by the No Child Left Behind Act of 2001 which requires each state to ensure that all schools and districts make Adequate Yearly Progress" (California Department of Education, n.d., n.p.). At the April 2009 meeting the Standardized Testing and Reporting (STAR) results, which are the means by which the AYP is measured, and efforts to support low-performing students were combined into a conversation about how the school was preparing for May's testing, as well as how the school was attempting to use testing results to support all of its students. The recent completion of mock testing to prepare for the STAR tests was mentioned, although results were not yet available. The chair of the board noted that it would be helpful at an upcoming meeting for the staff to share the results of the mock testing and to provide specific actions that were being implemented in order to support low-performing students. While suggested, this follow-up did not occur during the ensuing few months. It was also noted that the education committee of the board had not met in awhile. The committee had been chaired by one of the former university members on the board, but since her departure from the board it apparently had not been meeting consistently. The executive director's interest in thecommittee had been limited from the 
beginning; indeed, it had taken over 3 years to convince the executive director to create the committee.

Overall, conversations about academic matters tended to highlight the expertise of the board members-clearly there were board members who knew a great deal about these topics-yet in the end the conversations ended up going nowhere. Indeed, one of the board members, the CEO of an educational testing company who had provided the school educational software to track student work, attempted to help the administration frame the achievement problem in 2008 and utilize his and others' expertise. He suggested that the results from the 2008 STAR tests offered an excellent opportunity for the school to make some course corrections, and also noted it was "far from a calamity." He reiterated the role that the testing software could play, and stressed the importance of adopting a growth model for analyzing testing results instead of simply looking at averages. In particular, he emphasized that the AYP results, while relevant to the state and to the district, were of limited value to the school itself, for they looked at school averages, not individual student results, from year to year. In other words, a very strong $7^{\text {th }}$ grade class could be followed by a weak $7^{\text {th }}$ grade class, which would result in lower test scores in $7^{\text {th }}$ grade. The results, however, may not reflect real gains or losses by students. As he noted, "measuring averages, I'm not sure that is a good decision" (transcript of board meeting, October 6, 2008). He encouraged the school to create organizational memory about strategies that worked and to really utilize testing data to drive instruction. All of these suggestions appeared to fall on deaf ears. Undoubtedly, the lack of follow-through was undoubtedly due in part to the challenges the school faced 
during the 2008-2009 school year, yet it also underscores the difficulty boards have when venturing into these contested terrains.

\section{University Research}

The most visible crack in the veneer during this "normal operations" early period was a highly charged debate about the research being conducted by the university that emerged during the April 2008 board meeting. On the surface, the concerns highlighted distrust with the university's activities. From an analytical standpoint, however, the fears seem to reflect the complex role that research could play in a school and the location of these activities squarely in the contested terrain of educational operations.

Questions initially emerged during a discussion at the April board meeting about the university's research. A board member, who had joined in February 2008 and then subsequently resigned after only two meetings, had asked for the item to be placed on the agenda. The board member started by explaining he had had "a very unsettling discussion" with the education committee chair, who was also a lead researcher for the university partner. He explained that the researcher had been unable to answer him when he had asked if the university was trying to create an econometric model of what's being done at the school. He continued, "I wondered what the university is doing with all of its

different resources and I thought — does everyone know what [the research] is all about?" (transcript of board meeting, April 2008).

While the education committee chair was not present to answer his comment, a contentious discussion ensued between the new board member and the board secretary, who was also the dean at the university. The dean defended the research being conducted, 
noted that the school was carefully gathering qualitative and quantitative data and that they would only have 2 years of data as of the coming August. She stressed that it required at least 3 years of data to define a trend, and further stressed that the university's efforts were a small part of a much broader conversation. The new board member countered by asking if the school would be able to "identify 'if . . then' statements at .05 level of probability?" The dean dismissed the comment noting, "to turn it into a numerical analysis at .05 validity is not why I entered this profession" (transcript of board meeting, April 2008).

The conversation moved into other topics, although the tension remained high, and right before the meeting ended the new board member walked up to the board chair, handed him a letter of resignation and walked out of the room. People seemed a bit stunned, and then a collective relief seemed to sweep the room, as several board members spoke up and noted this would make the board stronger moving forward. The dean remarked that it suggested the need for a true vetting of new board members, while the board chair commented, "sometimes the chemistry is not there."

The reality, however, would prove to be more complex. In the ensuing weeks, it became clear that this new board member's concerns with the partnership were shared by other individuals within the school, including faculty and the executive director. Moreover, the conflict surfaced what would become an increasingly powerful perception in the community, especially among faculty, that the university and, in particular, the dean held undue influence on the board. As the school's financial consultant asked in an interview, "Is the university the dean, and is the dean the university? When someone says 
the dean was here does that mean the university made the decision? And if someone says the university, does that mean the dean?" (Financial Consultant, interview, January 2009). Following the meeting, a faculty member who had been in attendance at the board meeting sent a letter to the executive director explaining her strong misgivings with the partnership (Board Member, personal communication, May 2008). The letter then led to several conversations in May and June between members of the university and faculty members in an effort to better understand the conflict. These conversations were not raised at the board level, however, and did not appear on the board agenda. In addition, the story started circulating that the board member who had resigned had been prepared to provide the school significant financial support, thus creating the perception that the university partnership and a defense of the research had interfered with a potentially lucrative fundraising opportunity (Staff, personal communication, February 2009). While impossible to confirm its veracity, the story likely stemmed from a comment the new board member had made toward the end of his final meeting when he said he had contacted the dean about the possibility of working with her to get a grant opportunity which he would couple with his own money to provide every student with a computer. At the time, he made it clear he was not going to do this given the research model in place.

Viewed through the lens of management versus governance, the conflict exposes the challenges that emerge when the board engages in work that can be perceived as outside the realm of governance and moving into the management of academic affairs and thus threatening to school administrators and staff. Unlike negotiations with the school district or the maintenance of financial records, research about teaching and learning is at 
the heart of the school's daily operations. Under the right circumstances - a high level of trust between members of the board and the executive director, for example-that involvement might be welcomed. Indeed, the level of educational expertise on the board was impressive and the possibilities of leveraging that knowledge in service of the school undoubtedly represented one of the early reasons for the partnership. With a strong relationship between the board and the executive director and excellent lines of communication, one could envision a situation in which the university's research work would be welcomed. In the absence of those trusting relationships and also without effective communication, however, it is not surprising that the university's work was met with skepticism and distrust.

The conflict also raised questions about the lack of clarity around the partnership agreement. Research has consistently shown that successful partnerships are the result of well-articulated agreements and consistent re-negotiations of those agreements throughout the life of the partnership (Sanders, 2006). A review of the SDMS/university partnership reveals that the initial agreement was brief and that ongoing conversations about the partnership were not a common occurrence at the board level. The one-page partnership agreement, dated December 16, 2004, provides an overview of the support that the university intended to provide to the school, including student teachers, counseling interns, professional development, and university student tutors. There is almost no detail provided in the document about the specific supports, although there is reference to two future meetings as well as a reference to the intention of the university counseling department to implement a center for student support at the school (Board of 
Trustees, 2004). The document interestingly makes no reference to the expectations for the school vis-à-vis the partnership, focusing entirely on what the university will provide for the school.

Perhaps more importantly, the role of the board in managing the partnership was never clearly articulated in the document, something that became particularly important and challenging when this conflict arose. The presence of three university members on the board added to the challenge, for it became difficult for the board to play a role in managing a relationship in which several board members were intricately intertwined. In contrast, for example, the negotiations with the school district allowed the board to work together in conversation with an outside group, while the conversations about the partnership split the board itself and also created a complex relationship between the school's leadership team and key members of the board. In the final section I will look more carefully at how some of this confusion over board member roles arguably led to the dissolution of the partnership, but I want to turn my attention now to the second periodtumultuous times - and shift from an analysis of governance tensions to an exploration of communication tensions and the complex balancing act between transparency and confidentiality.

\section{Period 2: Tumultuous Times}

\section{Confidentiality Versus Transparency}

The board was consumed during the second period (June 2008-January 2009) by the resignation of the executive director and the subsequent search for her replacement. Analysis of the period brings to the forefront the tension between confidentiality and 
transparency. In the end, the period illuminates one of the challenges at the heart of board operations, particularly in the quasi-public realm of a charter school board of directors.

The board's decision to grant the executive director a 6-week contract and the executive director's subsequent resignation was a surprise, at least to the general community. An emergency meeting was called in late June 2008 to discuss concerns with the executive director. The meeting came on the heels of what had appeared to be an exceedingly positive year-end meeting in early June. Moreover, a local paper, the Voice of San Diego, ran an article in June touting the school as a model for charter schools in other low-income areas. The late June meeting started with a brief public comment period, that included testimonials from a former teacher, who had also been the teacher-representative to the board; a vice principal, who would later become the interim executive director; and an executive director from a neighboring charter school. The public comments suggested that people had different perceptions of what was really at issue. The former teacher and board member gave the executive director a vote of confidence and assured the board that he had not left because of the executive director, while the comments of the vice principal suggested that the developing antagonism between the school and the university seemed to be at issue. The school was out of session and there was a harried quality to the proceedings. Following the public comment period, the board went into executive session to discuss the executive director's employment, something it was allowed to do under the Brown Act.

Later interviews revealed little about what had precipitated the executive session. The public comment from the board at the end of the meeting simply indicated that the 
executive director had received a 6-week contract and that the board would be conducting an investigation of "issues that had been raised" in the coming weeks and then the board would determine the long-term fate of the executive director. The investigative process was short-circuited, however, when the executive director submitted her resignation, and thus a public explanation of the reasons for the executive session that had precipitated the 6-week contract was never provided. The executive director was quickly reintegrated into the San Diego Unified School District and was assigned as a principal at a public middle school.

Upon receipt of the executive director's resignation, the board appointed the vice principal as interim executive director and then began a search process for a replacement. Concerns about the search process emerged at the October meeting when the faculty representative to the board was given a spot on the agenda. She noted that faculty were anxious about the executive director search process and were eager for an update from the board. She noted, "It could be as simple as an update letter, the steps that we have taken, the steps we anticipate to take. The lack of communication makes people feel a little unsteady" (transcript of board meeting, October 6, 2008). The chair of the board offered a quick recap of the process, noting that there had initially been 27 candidates that had been paired down to 6 and then 4 . He noted that one of those four had been hired by someone else, and they were still trying to schedule time to interview two of the candidates. He then noted that two finalists would be asked to present to the staff. He quickly added, "by that time we still will not have selected someone," and suggested that the board would "monitor responses and reactions of the staff to the various candidates" before making a 
final decision. A few questions followed, including whether or not candidates had been notified that they would be making presentations. The board chair noted they had not.

The comments of the chair of the board underscored what was glaringly evident even prior to his comments - a clear hiring process had not been established. Instead of having something that had been clearly communicated to the community-the selection of a search committee, the publication of a position description and selection process, periodic updates about progress - the process seemed ad hoc. The chair of the board, who guided the process, failed to recognize the importance of transparency, particularly to the faculty and staff, as well as the need for a process that involved a broad range of community members. While it is true that the board of directors is ultimately responsible for hiring the executive director, the best processes, particularly within the relationshipbased world of non-profits, create opportunities for all constituent groups to offer feedback. A process that allows candidates to meet with a broad range of groups ensures that the candidates have a good feel for the position and the challenges that await them, ensuring a stronger possibility of finding a good match both for candidates and the school. Moreover, the decision to invite only two finalists in to meet with the staff, including one internal candidate, was almost a surefire recipe for disaster since it was quite clear that board members did not feel strongly about the internal candidate. When the other candidate failed to impress anyone, the board found itself in the exceedingly awkward position of announcing a failed search after the staff had overwhelmingly offered its support for the internal candidate (the vice principal of SDMS). 
The response from the community was explosive. Teachers, in particular, were up in arms over a perceived lack of teacher involvement in the process and the board, particularly the chair of the board, was characterized by several teachers as dishonest. Frustration which had been near the boiling point following the executive director's resignation over the summer exploded reflecting the broadly held perception, including from some board members, that the search had been "botched."

Ultimately, the departure of the executive director and the ensuing process revealed two common, but serious, challenges facing a non-profit board of directors (Houle, 1997). First, is the challenge of having board members who do not have extensive experience working in non-profit organizations trying to oversee an executive director selection process. The need for community involvement, for example, is an essential component of the search process, particularly in schools, yet it is something which might not be obvious to people who did not work in the non-profit sector. Compounding the problem at SDMS at this particular moment in time was that the one person who truly knew how to run an executive search in a school- the board secretary and former board chair-was perceived by many in the community as having caused the resignation of the executive director. Thus, she was not in a position to run the search and she found herself trying to offer input into the process from a distance. While the chair of the board may have been able to mitigate this by bringing in experts from outside consultants from a group like the California Charter School Association, for example-he apparently believed he knew enough to run the process and he failed to recognize his own lack of understanding. As one board member later noted, "It was a real fiasco the way it 
was handled and part of it ... he had never done it before and rather than listening to how it is usually done in education, he handled it how he would handle it in business" (Board Member, interview, January 2009).

The second, and arguably more significant, challenge involves the need to balance the tension between protecting privileged information that cannot be shared with the community and ensuring sufficiently transparent communication so that the community believes that the board of directors is carrying out its duties responsibly and ethically (DeKuyper, 2007). The executive director's resignation hit right at the heart of this dilemma, for the board was not in a position to divulge conversations that had been held while in executive session that led to the contract change and thus was not in a position to counter rumors that were circulating about her departure. There was a perception in the community, for example, that a strained personal relationship between the board secretary and the executive director, which had been exacerbated by growing discontent among school faculty about the university partnership, led to the executive director's "forced" resignation. The truth of this claim was indirectly disputed by a number of board members, although none was in a position to provide details into what had actually transpired. As one board noted in an interview:

On a board of directors you have a sworn commitment to professional courtesy and privacy. Sometimes the board has to make a decision and cannot defend itself publicly on that decision because of the employee's privacy. So you can be hit upside the head with rotten eggs and you have to take it. And that calls for restraint .... I'm a person who spent many years in the Civil Rights Movement, and one of my greatest pieces is due process. Knowing my background in civil rights and people saying you've been bought and sold, those are fighting words, but you take it and you deal with it. That's one of the hard parts of being on the board. (Board Member, interview, April 6, 2009) 
While the board may have handled the resignation properly, however, the dearth of communication surrounding the search was less explainable and ultimately led to the conflation of both events in the minds of many in the community.

\section{Communication and the Partnership}

Closely related to the conflict over the search was growing public concern surrounding the university partnership. Again, the conflict increasingly became about communication and the board's failure to effectively walk the transparency versus confidentiality tightrope. A document circulating at the December board meeting provided a "History of [the partnership]" from the perspective of at least one staff member who felt the partnership should be dissolved. The document outlined a series of complaints with the partnership - the university dominates the board, holds secret off-site meetings, and is unresponsive to SDMS staff concerns; the university has not met many of its promises, including failure to support board development and provide student tutors; the university-led professional development was seen as too research focused, impractical, and time-consuming; and research studies place demands on teachers without providing any useful results or data. The validity of some of these concerns was questionable, particularly the notion of secret off-site meetings, but a review of the issues clearly points to a serious communication breakdown.

Furthermore, speeches during the open comment section of board meetings revealed a panoply of concerns among faculty and parents (transcripts of board meetings, December 1, 2008, January 5, 2009). Among these were concerns that "the board and actual school have become separate entities," that the "the board is now dominated by the 
university," that "teachers and parents need to be listened to and need to be heard," and that communication was so poor that parents learned of the results of the executive director search through a phone call. The response by the board chair to these concerns offered important insight into the constraints, or at least perceived constraints, of the board's operations. According to the board chair, the board was required to listen and not respond during the open comment period as a condition of the Brown Act. He reiterated this expectation at the beginning of several meetings, clearly attempting to explain why the impassioned and occasionally tearful speeches of community members received no response from the board.

A review of the Brown Act suggests that the board chair's interpretation of this particular practice is questionable, yet the impact of the Brown Act on the board's operations is significant (California Government Code, $\S \S 54950-54963$, cited in Lockyer, 2003). Indeed, the Act's impact was far-reaching and led in large part to the inability of the board to fully operate as an effective non-profit board and forced it to increasingly take on the contested, highly political character of a traditional public school board. Under the Brown Act, all board meetings had to be public, with the exception of closed sessions dealing with personnel matters, pending litigation, labor negotiations, or real property negotiations (California Government Code, $\$ \S 54950-54963$, cited in Lockyer, 2003). The preamble to the act offers the rationale for its creation:

In enacting this chapter, the Legislature finds and declares that the public commissions, boards and councils and the other public agencies in this State exist to aid in the conduct of the people's business. It is the intent of the law that their actions be taken openly and that their deliberations be conducted openly. The people of this State do not yield their sovereignty to the agencies which serve 
them. The people, in delegating authority, do not give their public servants the right to decide what is good for the people to know and what is not good for them to know. The people insist on remaining informed so that they may retain control over the instruments they have created. (California Government Code $\$ \S 94950$, cited in Lockyer, 2003).

As a result, the board was forced to conduct nearly its entire operations in public. In the context of the crisis, it appears that the board was never able to confidentially discuss its options and share thoughts about how it might better address the crisis. As a result, the board simply seemed to abdicate its responsibility to have the conversations, choosing to remain silent and follow the lead of the chair of the board.

The concerns about the partnership did not simply get voiced during the public comment period. A petition calling for the dissolution of the partnership circulated among the faculty (receiving signatures of more than 20 faculty members) and then appeared on the board agenda in January. The board chair again invoked the Brown Act and remarked that he was "happy that we received the letter signed by the faculty, now we can take action. That's why we couldn't respond before because it came in a public communication, you can't take action or do anything unless it appears on the agenda" (transcript of board meeting, January 5, 2009). The chair of the board called for the creation of a fact-finding group to review the "charges" against the university partnership and to determine if the petition had merit. He noted that the fact-finding group should then suggest what, if anything, needed to be done to resolve the crisis.

The actions of the board chair were confusing on several levels. First, there is no language in the Brown Act that limited the board's ability to have addressed these concerns earlier (Lockyer, 2003). While the Brown Act does require items to be on the 
board's agenda, there is no reason why the chair of the board could not have placed this item on the agenda without receiving an official petition from the faculty. Indeed, concerns with the partnership had been brewing for months and had been voiced at earlier meetings. Second, his decision to create a fact-finding committee suggested that the board had no understanding of the partnership or whether or not the faculty's charges of inappropriate activity by the university were valid. Indeed, one of the board members from the university remarked toward the end of the conversation on the situation:

I think the sadness in this situation, not just about communication, no one feels valued. I can tell you my faculty does not feel valued either . . . . I've listened and I've listened, and I've internalized a lot of this, they've given a lot down here, there are very highly trained people. The crime of this situation would be if we can't pull it together. This is not about adult agendas, this is about these kids and their futures. (transcript of board meeting, January 5, 2009)

The lack of public support of the partnership ultimately signaled the beginning of the end of the partnership, but also strained the meaning of transparency versus confidentiality. The board chair noted, "I want to give you guys [the faculty] whatever you want, so we're going to find a way to give everyone what they want" (transcript of board meeting, January 5, 2009).

The deeper issue here, as noted earlier, is the real constraints and perceived constraints that the Brown Act placed on the board's ability to handle a very complex crisis. Non-profit boards have traditionally tried to minimize the overtly political quality of their proceedings, with trustees holding closed meetings that allow confidential conversations that emphasize long-term interests and needs, not short-term, politically expeditious results (DeKuyper, 2007; Innes \& Booher, 2004). Certainly there is a danger 
that boards veer too much toward confidentiality, and Sunshine Laws, such as the Brown Act, are certainly efforts to avoid mismanagement and malfeasance on the part of a board. Yet the other danger is equally damaging, that boards may veer so much toward transparency that they cease to be in a position to handle difficult challenges. The SDMS board, in some ways, struggled on both accounts, mismanaging its communications about important topics like the executive director search, thus creating the appearance of being secretive. At the same time, in its efforts to meet the constraints of the Brown Act and trying to be transparent, it was unable to have confidential conversations that might have allowed the board and the school to move forward. Part of the problem may have been that the board lacked sufficient expertise about how to best manage the Brown Act during this 16-month period. Interviews with board members revealed that early in the charter's history a lawyer did sit on the board who offered guidance on the Brown Act and its implications, but during the majority of this period no lawyer was present.

Chait et al.'s (2005) concept of generative governance is helpful in this context. According to them, boards need to develop the capacity to address generative challenges or what Heifetz (1994) referred to as adaptive challenges. They point to generative landmarks, including ambiguity, saliency, stakes, strife, irreversibility. The school/university partnership signaled all of these aspects, including ambiguity (multiple interpretations), saliency (high meaning to multiple stakeholders), stakes (discussion of core values or meaning), strife (high possibility of confusion and conflict), and irreversibility (mismanaging leads to both psychological and financial irreversibility). When wrestling with these generative challenges, Chait et al. (2005) argue that the focus 
should be on finding a way to "frame decisions and choices, not make them" (p. 120). With this end in mind, they encourage boards to suspend normal board operations and engage in out-of-the-box thinking, potentially involving the consideration of counterfactuals and hypotheticals, trust intuition, and promoting honest and "robust dialogue." As they write, "boards need to preserve civility but curb the dysfunctional politeness and 'groupthink' (Janis, 1982) that chill generative thinking”' (Chait et al., 2005, p. 125).

The possibilities of generative thinking are exciting and, as noted above, could have been well-utilized in this situation. Sunshine Laws like the Brown Act, however, impede this type of conversation (Innes \& Booher, 2004). How can a board have freeranging, open conversation in a public venue in which any comment may be misconstrued or misused? As one board member noted during an interview, for example, the school could not actively engage in conversations about potential mergers, for example, as those would immediately become part of a broader public dialogue which could sink the ideas before they even had a chance to be vetted or understood. "[The Brown Act] does not allow for the free generative kind of ideas .... We can't be generative" (Board Member, interview, January 9, 2009).

A somewhat ironic, yet telling, exchange occurred during the January meeting which highlights this challenge. One of the soon-to-be new faculty representatives to the board, a person who had argued vociferously that the board had not operated openly during the preceding months, started to explain his concerns with the partnership: 
We have a communication problem, that's very obvious but there's also some structural issues with the partnership and how it manifests itself here. One structural problem is the make-up of the board in terms of the university and its membership on the board. The impact it has is being overrepresented on the board. (transcript of board meeting, January 5, 2009)

At that moment, the chair of the board asked, "What was the issue with that?" The teacher started to respond, "Teachers don't understand why the university ..." and then paused mid-sentence. "I don't feel it is appropriate to talk about that at this point." The board chair then quipped, "You're beginning to sound like a board member." Clearly, the teacher recognized the same issue that other board members recognized-it is very difficult for a board to have open, honest conversations about these types of issues in a public forum. The board's options were severely constrained by this structure and, in the end, led at least in part to the board's shift from a more traditional non-profit model to a public school board model. I will address this shift in the next section as we turn our attention to the final period--a troubled peace - and issues of the appropriate roles of board members.

\section{Period 3: A Troubled Peace}

During the final period of my study, there was a visible shift in the operations of the board. Analytically, this shift can be best understood by looking at the role of board members as they shifted from a traditional non-profit focus on trusteeship to a more public school board model of representation. As trustees, board members are expected to "function as guardians and policy makers who are responsible for the organization's mission and resources" (Widmer, 1993, p. 341). Board members are expected to adopt a long-term perspective and not become embroiled in day-to-day issues. Representation, on 
the other hand, reflects the traditional public school board model. Elected to their positions, public school board members represent distinct interests and their decisions often reflect current political tensions or issues. Within SDMS, representatives focused primarily on understanding and representing the viewpoint of a specific constituent group - faculty or parents, for example - as opposed to the long-term interests of the school. The impact of this change was unclear at the end of this period, although the resignation of a number of board members signaled that it would be a very different board that would start the 2009-2010 school year. In this section, I will review the original process utilized to create the board and then explore how the tensions during both the second and third period of this study led to a shift in the board's membership and operation. In addition, I will explore how limited understanding of non-profits, at both the executive director and board level, accelerated the changes in structure and operation and raised serious questions about the school's long-term viability.

\section{Board Composition}

Research suggests that charter schools have consistently struggled to create and sustain effective boards of directors (Hill \& Lake, 2008; National Resource Center, November 2008). The initial creation of the board at SDMS would seem to belie this struggle. The initially constituted and maintained board of directors had a great deal of financial, legal, and educational expertise. A review of the process to enroll board members since the school's inception shows that the board composition had been accomplished purposefully and thoughtfully. This group of directors focused primarily on the role of trustee, as opposed to representative. Widmer (1993) offers a helpful definition 
of these terms, as he catalogs the myriad roles that directors play. In describing the trustee role, Widmer references Houle's $(1989,1997)$ guidelines for appropriate board functioning when describing this role. On the other hand, Widmer explains, representatives "speak for or carry information to and from individuals, groups or organizations" (p. 342).

In essence, the original constitution of the SDMS board seemed to be premised on the importance of bringing together a representative group of people yet not relying on those people to simply serve as representatives. While there was an expectation that these people would share the board's work with their constituencies - at least in the case of university partner members, parent members, and faculty members to the board-board members described their role as that of trustees, focusing on the long-term sustainability of the organization not merely the short-term needs of their constituents.

From its inception, the school's bylaws provided explicit guidelines for board composition. According to the bylaws, the board would have no less than 3 and no more than 15 members. In the original charter approved by the district, the school noted that board members will "represent the community-at-large, the business community, and educators" (Board of Trustees, 2004, p. 18). The charter also included an appendix (appendix "B") listing the "initial seating" of the board, which included one parent, one educator, one administrator, one community member, and two business persons (community and regional).

The founding board chair, who was also connected to the university and who later became the board secretary, explained that the original formula had been driven not only 
by a desire to get a variety of voices on the board, but also in response to the demands of a grant funder (a major foundation in the community). In addition, the school was following right on the heels of another conversion charter school that had partnered with another major university. This conversion charter school was led by an executive director who had been the principal at SDMS right before the conversion and had been a mentor to SDMS's executive director. Thus, when the other school asked for three representatives from their university partner, SDMS followed suit (Founding Bard Chair, interview, January 2009). From the beginning, the founding board chair noted, the school had kept a chart tracking the members and had sought to ensure that there were representatives from each category that actually exceeded the minimum standards articulated in the appendix to the charter. Copies of these charts from the first few years show that the original goal was to have three parent members, two community members, three business members, three university members, and two ex officio members, the executive director and one teacher representative. During these early years, this shifted to two parent members and four business members, although the dean of the university noted she persistently pushed to have an additional parent member. Interestingly, a review of these documents reveals that there was a consistent core of members who had been part of the charter school since the beginning, while several positions seemed to persistently become vacant, including the additional business member position and the community member position. A third parent representative seat was absent throughout most of the first few years, something which the founding board chair argued was due to 
the perception of the executive director that there were no parents who were capable of filling the role (Founding Board Chair, interview, November 2007).

In February 2008, when the research began, the board was made up of 12 members. Reviewing the composition chart that was maintained by the board secretary, members were classified as follows: three partner university members, two parents, one community member, one lawyer, four business members, and one teacher. One of the parents was also a prominent businessman and community leader. The lawyer had just joined the board at the February meeting, and one of the business members had also recently joined. Of the 12 members, 8 had been part of the board since the school's inception in 2005.

Conversations with this original group of trustees suggest that the school had enlisted a number of experienced trustees, and they were able to easily articulate the classic division between governance and management that is at the core of non-profit governance literature and best practice. These members understood the importance of the trustee role-providing oversight to ensure the organization's long-term sustainability and ensuring the organization meets its fiscal and legal obligations-and also recognized, at least in theory, the importance of not micro-managing the school's day-to-day operations. As the finance committee chair explained:

Governance means hiring the executive director/principal. Governance means developing policy and instituting and implementing the policy that's adopted. Governance means to provide fiscal responsibility and keeping the institution solvent, making wise decisions in terms of achievement, academic hiring, academic philosophy, and those issues. (Finance Committee Chair, interview, 2009) 
Along the same lines, and using similar language, the board secretary noted,

A good board is going to focus on hiring the executive/director principal .... A good board is going to ensure that all the basics are done. In other words, there is a fiduciary responsibility, that there are the appropriate committees and subcommittees of the board, that the information about the board is transparent ... that they are involved with the strategic decisions, that they may be involved with strategic planning, but strategic decisions not day to day operations in any way, shape or form. (Board Secretary, interview, 2009)

The consistency of the responses is telling, and was also consistent with responses from several other experienced board members.

\section{Shifting Role Expectations}

One of the most concrete outcomes of the conflict that arose in December 2008 and January 2009 was the addition of three new board members, two faculty members, and one grandparent. These board members, unlike earlier members, were brought on in overtly political times and their membership was viewed as clearly in the representative mode, not trusteeship. Indeed, the addition of these board members was offered as a means of addressing concerns that faculty and parents were not represented on the board (transcript of board meeting, January 5, 2009). During an interview with the grandparent, for example, it became clear she did not embrace a classic non-profit vision of governance. She envisioned a board that solicited the perspectives of all members and that, at least as she seems to be describing it, brings together the disparate elements of the community and attempts to ensure that everyone is working in concert to improve the school. While not entirely inconsistent with a more traditional non-profit board model, her ideal board seems significantly more engaged in the day-to-day life of the school than a traditional non-profit board. 
I think our role is to monitor the school and more to keep it this school and I think we have to put the safety and the education of the children as our first priority and I also think that we need to interact in harmony .... Kind of like the three-legged stool, there are the students, there are the teachers and there is the board and we need to all respect each other and we all need to be listened to here .... We need to hear everything ... this way we can all be working together, I feel like we're working together as a family. (Parent member, interview, April 9, 2009)

One of the new teacher board members also described his role as representative, a notable shift from the trustee role articulated by other board members.

As a teacher representative, [my role] will be to represent the teachers and represent their voice as much as possible which can be difficult because there are a lot of teachers and they may not always agree .... I think you've got to go with where the majority of the staff is. So if there is an issue on something you got to try to see where most of the staff are and go with that. (Teacher Representative to the Board, interview, February 18, 2009)

This shift in board composition means a shift in perspective. It is important, for it potentially opens the door to conversations about day-to-day issues and operations, and it can move the board away from its governance role. Instead of adhering to a more classic non-profit trustee role classically that focuses on the long-term view of an organization, this representative oriented board may take on a greater management role.

A strong representative role also shifts the board in a more overtly political direction. The addition of the faculty and parent representatives clearly reflected a need to respond to the political turmoil that was embroiling the school. As Widmer (1993) notes, certain roles can actually interfere with the traditional trustee role. This representative role would seem to have great potential for creating a political board focused on the short term, not a board that focuses primarily on the long-term sustainability and success of the organization. 
The presence of faculty and parent representatives also speaks to a central tension in charter school governance, namely the question of the appropriate role for these constituent groups (Smith et al., 2007). Again, while having representative voices can be beneficial to an organization, the vested interest of faculty and parent groups can also interfere with the more impartial perspective that is often desired of board members. Interestingly, while some states, such as Minnesota, have required schools to have teachers on their charter school boards, other states have expressed concerns that teacher membership could potentially represent "a conflict of interest in having teachers set policy that affects the conditions of their own employment" (Smith et al., 2007, p. 22). While there was some discussion about the importance of having teacher representatives to the board recuse themselves from votes during certain issues, it was not clear that the full implications of adding teachers as voting members had been vetted during spring 2009. Indeed, conversations at the April 2009 meeting about the need to update board policies suggested that there had been little consideration of the full legal implications of this change (transcript of board meeting, April 6, 2009).

\section{Reframing Earlier Debates}

The addition of overtly representative board members also sheds an interesting light on the conflict with the university partnership. Public comments at the various meetings, as well as the comments of the new teacher representative board members who had been some of the most ardent opponents of the board's early activities, suggest that the broader community had a representative model as their mental model. With this framework as the context, the distrust and anger at the university board members makes 
more sense, for members of the community believed that university members when making decisions must be representing the interest of the university. The accusations of backroom deals become more understandable, as community members struggled to make sense of why the board would make decisions which did not reflect what they saw as the will of the community. The only option they seemed able to conceive in their mental model was that in some way the decision was benefitting the university.

An exchange at the January 2009 meeting again sheds some light. Following the decision to not hire the former vice principal as executive director, the board chair had remarked about the need to move forward. "You're going to have to trust the board has acted in the best interest overall for the organization. We're going to have to begin anew and say this is what I'd like to see tomorrow." One of the new faculty members to the board jumped in, commenting, "The decision [to not appoint the vice principal as permanent ED] has impacted the school in a negative fashion .... When you said you made the decision and it was best for our school overall, I am here every day and it was not in the best interest of our school" (transcript of board meeting, January 5, 2009). This same faculty member was leading the charge against the university partnership, apparently convinced that the board and the university were in some ways indistinguishable and that the board had acted in the interest of the university.

In the end, some of this confusion stemmed from two failures of the board. First, the board failed to educate the community and themselves about their role as a board of directors. Instead, the board responded to a crisis by overtly shifting the role of board members from a trustee role to a representative role, allowing the prevailing mental 
model of the community to replace the trustee model which had been the original vision of the founding board and which had its root in the literature about good non-profit governance (DeKuyper, 2007; Houle, 1997). Second, the board failed to recognize the potential conflicts of interest which existed with its university members and never overtly addressed the need to proactively discuss these potential conflicts. For example, the board did not seem to recognize the challenge created when you have board members who are also conducting research and providing professional development for faculty members. While people can certainly occupy these multiple roles, the situation needs to be managed proactively and the communication of roles and expectations needs to be crystal clear. In the absence of that communication and amidst the appearance of a crisis, members of the community made the logical—although not necessarily accurate—assumption that somehow the university was driving changes in order to benefit itself.

The other major factor at play was the lack of executive leadership throughout the period. In spring 2008, the executive director failed to explicitly support the partnership when it came under attack and allowed the community to question the value of the partnership and the role of research at the school (Board Members, personal communications, May 2008). Publicly, the executive director said nothing, while privately the executive director appeared to support the efforts of faculty who were questioning the value of the partnership (Board Members, personal communications, May 2008; Board Member, interview, January 2009). During the remainder of the period, there was no true executive leadership. As one board member noted looking back at much of the period, "the root cause [of the partnership problems] is we are missing a leader .... 
An executive leader would in fact take and say this is what we are doing and why we are doing it. I don't think they would just say this is because the board wants it this way" (Board Member, interview, February 18, 2009).

\section{Is the Administrative Structure Sustainable?}

The board had an opportunity to address this lack of executive leadership during the spring and to consider how to create an administrative structure which would have long-term viability. The dissolution of the partnership and the movement of the board toward a representative board, however, prevented a serious consideration of the administrative structure and led to a decision based on the short-term desire to generate the least resistance. Again, this issue highlights the shift in board role, as the board essentially abdicated its responsibility to hire a new executive director and instead decided to support a proposed administrative restructuring presented by the interim executive director and the vice principal who had been passed over initially for the role of executive director. The concept of a restructuring was a good one; indeed, research suggests creating a sustainable administrative structure is a common problem in charter schools (Deal \& Hentschke, 2005). Deal and Hentschke (2005) argue, for example, that successful charter school leaders tend to resemble business entrepreneurs, not traditional public school administrators. The experience at SDMS suggests that a public schoolmindset may actually be a hindrance to successful charter school leadership.

The notion that the executive director position required too much of one individual had actually arisen prior to the tumultuous events of June, yet there did not appear to be any concrete plans underway to address this challenge (transcript of board 
meeting, May 5, 2008). During interviews, a number of individuals noted that the job required, as one board member put it, a "super human being" (Board Member, interview, February 18, 2009). As he noted, the need to be both an instructional leader and a chief executive officer required not only a broad skill set, but also someone who was willing and able to work a phenomenal number of hours. Compounding this problem, public school principal training focuses primarily on instructional leadership and does not include the non-profit management training which is so essential for running a charter school. The simplest solution would seem to be the creation of two positions-an executive director and an instructional leader. The executive director would have primary responsibility for working with the board of directors and overseeing the successful operations of the school, including facilities management, work with the district, fundraising, and development of and successful communication of a vision with both internal and external communities. The instructional leader, on the other hand, would report directly to the executive director and would be charged with working with teachers to develop the academic program and focus on student achievement.

At a board meeting in January, the chair of the board suggested that one of the problems with the search had been the effort of the board to hire someone to do a job that had already been recognized as exceedingly difficult if not impossible, instead of spending the time to create a new, more sustainable administrative structure and then conduct a search for the appropriate person or people (transcript of board meeting, January 5,2009 ). His comment hinted at what would eventually happen during the spring, which was the creation of an alternative model created by the new interim executive 
director and the original interim executive director who had unsuccessfully applied for the position. While their proposal was ultimately adopted, however, it fell far short of creating the sustainable structure needed for the school. The model called for the creation of a new part-time position-administrative support--which would report to the principal and would be responsible for oversight of the strategic plan, the charter revision process, WASC accreditation, submission of Proposition 39 paperwork, and "other duties as assigned." The description seems to suggest a high-level support staff person who can do many of the administrative tasks associated with these somewhat ad hoc processes. The principal would be the direct report of the board and would remain responsible for the daily operation of the school, instructional leadership, parent/community involvement, evaluations, budget, working with the board, and partnerships. In essence, the model suggested no real substantive changes, but rather the simple addition of another support person to relieve some of the pressure on the principal.

The board conversation surrounding the new structure was awkward at best, with several board members noting that approval of the new structure was in essence approval of hiring the vice principal, who had been passed over in the first selection process, to become the principal and the current interim executive director to become the administrative support person. Indeed, during the conversation it became clear that members of the board who had originally opposed the vice principal as the new principal were simply acceding to the perception that the school had undergone too much turmoil. One of the new faculty representatives to the board noted, "I support the plan, the staff 
support the plan, and I do not think it would be a good idea to introduce a change again" (transcript of board meeting, April 6, 2009).

More significantly, the conversation revealed significant gaps in the understanding of non-profit governance by the interim executive director and vice principal, a gap which members of the board pushed on as part of a spirited dialogue. The original plan presented to the board had both the principal and the administrative support person reporting to the board, an unprecedented, and arguably impossible, situation in a nonprofit governance model, as it meant that there was no single individual charged with overseeing the operations of the school. Moreover, the plan gave no clear sense of who would be responsible for key duties, such as human resources. During questioning, the leadership team became visibly frustrated and several times suggested that the board was seeking out details that would be ironed out as things began to unfold. The most concerning moment occurred when the vice principal, who would soon become the principal, noted that it was difficult to firmly establish parts of job descriptions, such as who would have responsibility for facilities management, because at some level it would restrict the school when hiring if a potential hire didn't have that specific skill set. Incredulously, one of the board members asked, "Why would you hire this person?" and then quickly added, "So you'd change the job description?" Another board member jumped in to clarify that the board was not seeking absolute clarity nor suggesting that any change in a job description required board approval but, he argued, "we're saying it cannot be whimsical," pointing out that the school could find itself in legal hot water and potentially face a lawsuit if its hiring policies were not consistent with the law. He went 
on to note that the changes being proposed would require a careful review of the school's policies, as new position and position descriptions could require revisions in policy. One of the faculty representatives eventually jumped in to echo his own surprise with the leadership team's reticence in providing clarity. "I agree with the concerns of the board, and I don't think it's a guessing game. I also don't think it is 10 hours of work. I think it's very doable in a short amount of time"' (transcript of board meeting, April 6, 2009).

Ultimately, the board approved the changes at the April meeting, with the understanding that the school leadership would revisit the changes and attempt to provide clarity for the issues the board raised. The debate underscored what had been revealed during the search process, that the vice principal had relatively weak communication skills, limited understanding of governance, and no strong sense of the possibilities inherent in the charter school model. 


\section{CHAPTER 5}

\section{CONCLUSIONS}

\section{Postscript to Final Meeting}

The final meeting in June 2009 offered a somewhat surreal ending to the 18month research process. On one hand, there were clear glimmers of hope, as the board and the community shared the results of a recently initiated strategic planning process. The strategic planning process was a key component in the early stages of the school's charter renewal process, and was guided by an outside consultant. The initial outcomes of the strategic planning session suggested that the school had covered some important ground during the 2-day process. The retreat had involved 25 people, including staff, board members, representatives from the school's partner EMO, a local pastor, and a few parents. The majority of participants were staff, including administrators and teachers. The initial work from the 2-day retreat was visible on the walls of the meeting room, and included a pictorial timeline of the school's early history, notes from group brainstorming responses to various prompts, and even some mock newspaper covers from 2015, which were intended to represent people's visions of the school's future. Comments made during the board meeting captured the positive energy that had apparently pervaded the event, as well as the sense of community involvement and engagement. For example, one of the ExEd representatives noted, "It reminded me of when the school was originally formed, where they were a lot of community meetings and parents involved. This weekend there were parents here, teachers, staff, the leadership ... There was a lot of positive energy in terms of the future for the school" (transcript of board meeting, June 2, 
2009). Another board member noted, "I didn't want to go home at the end of every day," while the chair of the board remarked on the skill of the consultant and her ability to keep the process focused on the future. He remarked, "Instead of worrying about yesterday, she masterfully got everyone to worry about tomorrow because that's what it's all about" (transcript of board meeting, June 2, 2009).

Yet amidst this positive new spirit, the board appeared to remain woefully unprepared to handle the challenges ahead. Only three board members had participated in the full process (the two faculty representatives and the new parent representative), while the board chair had attended a portion of the event. In addition, the incoming principal failed to provide much reassurance as to his ability to handle his newfound responsibilities. During the meeting, he stumbled through an initial attempt to describe the process. The chair of the board then asked for a clarification on one of the items on the plan: "Can you explain what you mean by building leadership capacity within the community?" He initially said nothing, allowed two other people to make short comments, then stumbled a little by saying, "From my understanding . . . from what I recollect ..." at which point another member of his administrative team answered the question. Ultimately, it was left to the chair of the board and the outgoing interim executive director to redirect the conversation and effectively communicate the positive feelings that had been generated during the weekend retreat. As noted earlier, the incoming principal was a career public school administrator who had clear strengths in his ability to manage many of the processes essential to the smooth running of a school. He was not, however, a visionary leader and he did not appear to possess the skill set that 
would be needed to effectively guide and direct the strategic conversations at the board level which would need to occur in the future.

The icing on the cake, so to speak, was the literal sharing of a cake thanking the university for its 4-year partnership. The gesture, a gracious yet awkward attempt to bring positive closure to a tumultuous relationship, obscured the absence of a more important conversation that the board, yet again, did not address- - the imminent departure of nearly half of the board members and the pressing need to find replacements. Five of the 11 members were planning on leaving, as the three university members and two other board members, including the chair of the finance committee, resigned as a result of the dissolution of the partnership. Apparently, the board would have to wait until the 20092010 school year to wrestle with that important issue.

\section{Research Questions Revisited}

The 16-month study of the SDMS Board of Directors proved more eventful than originally expected. The resignation of the executive director, the failed search for a replacement, and the dissolution of the university partnership left the board operating in crisis mode for a significant portion of the period. Amidst this often chaotic landscape, board governance emerged from the shadows and took on a more public role than typical. The result was a rich period for analysis that offered important insights into the role of a conversion charter school board of directors.

In this final chapter, I will build upon the answers to the two research questions at the heart of the study: What role did the non-profit board of directors play at the school? How did a non-profit board of directors impact the reform efforts of an NCLB-conversion 
charter school? As noted in Chapter 4, the board succeeded in meeting some of its fiduciary responsibilities—particularly fiscal and facilities management—but foundered in its ability to provide the leadership needed to guide the organization through a tumultuous year. The board's challenges were clearly connected to the absence of strong leadership at the executive director level, as well as a board chair, during this period, with limited understanding of school governance. In the end, the board as it was initially constituted dissolved and left the organization in a tenuous place as it moved into the final year of its initial 5-year charter. Arguably the majority of the board's greatest contributions to the school—fiscal discipline, for example—were provided by board members who resigned at the end of this period, suggesting a leadership vacuum at the board level which would be difficult to fill. Most distressingly, neither the remaining board members nor the new executive director seemed to recognize the extreme challenges that lay ahead.

\section{Contributions to the Literature}

Charter school reform has, at some level, never been more popular (Landsberg, Smith, \& Blume, 2010), and yet a year at SDMS reveals the limits of that potential and the clear pitfalls that can arise as charter schools struggle with questions of governance. While much of the charter school research remains focused on understanding the academic impact of charter schools, this study reveals that governance challenges can impede the ability to ever get to that conversation. Concerns about executive leadership, the role of the board of directors, and the challenges of partnerships serve as important 
reminders to policymakers that charter schools are not a simple silver-bullet solution to the complex problem of traditionally under-performing and under-resourced schools.

This study built on the existing literature to illuminate several tensions that inhere in the charter school board structure-governance versus management, confidentiality versus transparency, trusteeship versus representation. The fact that this is a conversion charter school, and not a start-up charter school, is worth noting, for it implies a context that is even more challenging than other charter schools. The effort to renew a historically failing school is a daunting task and the governance issues that arise in this context may differ from those that arise for a board that is constituted in a start-up charter school. Understanding the tensions discovered at this conversion charter school, however, should prove helpful for all charter school advocates. A review of this study suggests the necessity for charter school boards, executive directors and other school reformers to consider three key areas:

- Building the leadership capacity of both boards and executive directors in charter schools through increased training and the creation of clearer expectations for their roles as well as guidance about how boards and executive directors can more effectively work together.

- Analyzing Sunshine Laws, such as the Brown Act, with an eye toward helping boards more effectively manage these complex requirements and, in the long run, potentially advocating for changes to these laws to allow for higher quality governance at charter schools. 
- Recognizing the difficulty that often exists in partnerships, particularly university partnerships, and taking proactive steps to create successful partnerships that will capitalize on the vast potential that exists to help create successful schools.

In the following section, I will discuss each of these areas and then move into a final discussion of the limitations and delimitations of the study as well as areas for further research.

\section{Building Leadership Capacity}

The National Association of Independent Schools (NAIS), an organization that supports private, non-profit independent schools with governance structures akin to the charter school model, has often touted statistics about the average tenure of a head of school (the equivalent of an executive director in a charter school). According to NAIS Executive Director Pat Bassett, the average tenure for a head of school was around 6 years in the early 1990s and then improved to nearly 9 years by 2006 (Bassett, 2006). Bassett and others, using data from surveys in 1991, 2001, and 2006, attribute this rise to the dramatic improvement in education for boards and heads of schools coupled with an increasing synergy in the role expectations for both groups. A review of NAIS initiatives from the last 15 years-- the creation of a set of principles for good practice for independent schools and the development of a fellowship for aspiring heads, for example — highlights their efforts to better train heads of school and boards, both separately and then together. 
Groups such as the California Charter School Association could play an invaluable role in spearheading education for effective charter school governance. Reviewing the struggles at SDMS, the effective utilization of an organization like the CCSA seems that it would have been valuable, but the question remains, what would this education emphasize?

\section{Best Practices for Boards of Directors}

Boards need consistent training in what is the most effective role they can play in supporting the long-term sustainability of the school. The founding board chair at SDMS did provide trustee best practice information, developing a trustee handbook, for example. The handbook included key information for the school, including the school's original charter document, board bylaws, and a document explaining the roles and responsibilities for board members (Board of Trustees, 2004). A review of the roles and responsibilities suggests an effort to get people to adopt the trustee role outlined throughout this study, including an emphasis on recognizing the need for the board to "ensure the school's financial viability," "hire, support and nurture the school's Executive Director," and "understand that while the Board sets policy, it is the administration that manages the school's day-to-day operations" (Board of Trustees, 2004).

During the 16-month period that I studied, however, there was no evidence of ongoing board training or conversation about the role of the board at any meetings. As one example, a conversation about the role of the board and the executive director vis-àvis the university partnership may have generated important insight into the confusion that surrounded the partnership and much-needed clarity as to how it should be better 
structured moving forward. As another example, the unconscious--yet significant- - shift from a board focused on trusteeship to a board emphasizing representation would have been less likely to happen in a climate where regular conversations took place about governance and appropriate roles for directors.

So what are the appropriate roles for a board of directors? The past year at SDMS would seem to reinforce the prevailing wisdom of non-profit scholars such as Chait et al. (2005) and Carver (2006) that boards should focus on fiduciary responsibilities, strategic planning, and policymaking, and away from engaging in operational management. The majority of charter schools that fail are the result of financial mismanagement or malfeasance (Smith et al., 2007), emphasizing the importance of having a board that is able to carry out effective financial and legal oversight. Interestingly, despite all of its other troubles, SDMS appeared at the end of this period to be financially sound. The loss of the finance chair and the failure to find a replacement, however, did not necessarily bode well for the future.

The work that created the most conflict—research and the role of the partnership - was the area that was most closely related to daily, operational management. The board may have benefitted from more clearly demarcating the role of the board from the work of the partnership, thus avoiding the appearance of role conflicts. As an example, the board may have placed fewer university members on the board of directors and instead placed them on a robust partnership committee that was reporting on a regular basis to the board. As another alternative, the board could have more effectively utilized its education committee to actively support and provide oversight of the partnership and 
the research that was occurring at the school. Either way, the board needed to actively oversee the partnership, something that a number of individual board members recognized but something that the collective group proved incapable of accomplishing.

\section{The Role of the Executive Director}

One of the challenges SDMS faced was the lack of an executive director who understood governance and how to effectively work with a board of directors. Several studies have noted a disconnect between traditional public school training for principals and the demands of the charter school executive director position (Hill \& Lake, 2008). A traditional public school principal focuses heavily on student learning and faculty professional development, relying on the district office and the superintendent to provide many of the essential support services, such as financial oversight, as well as expecting those offices to set a general direction for the district and, in turn, for the school. From a structural standpoint, the principal reports to one person-the superintendent. A charter school executive director or principal, on the other hand, is expected to oversee all aspects of the school program, including financial and facilities management, fundraising, faculty professional development, and, of course, all aspects of student learning. Structurally, the charter school principal is the sole employee of the board of directors, meaning, in essence, that the principal reports to a large group of volunteers. Working with this group is a complex and highly political activity and something for which there is no equivalent experience at the traditional principal position. Finally, the broad vision of the school-something that is heavily influenced by the district office and superintendent 
in a traditional public school—rests primarily in the hands of the charter school executive director.

Given the significant differences in these roles, the skill set for the two positions is understandably quite distinct. As Deal and Hentshcke (2005) note, the charter school executive director position offers several opportunities not found in the traditional principalship - the "chance to play" created by increased autonomy, the "opportunity to operationalize cherished, firmly held personal beliefs," and the celebration of the spirit of entrepreneurship. As they write,

Regular public school leaders ... emphasize priorities other than entrepreneurial ones, such as faithfully discharging system responsibilities, balancing competing political demands, upholding professional norms, faithful stewardship of public resources, procedural compliance and inclusiveness .... Like starting a business, starting a charter school seems to require (and to attract) people who are ambitious, optimistic, financially canny, driven by a compelling vision and attracted to a high-risk endeavor by the possibility of success associated with high degrees of autonomy. (pp. 3435)

The only piece missing from their description is the ability of the executive director to work collaboratively with a board of directors, something that was clearly a significant factor in the struggles at SDMS. In the end, one of the lessons from SDMS is that the skill set of a public school principal is not necessarily a natural fit with the charter school principalship. Boards of directors need to recognize this when hiring and supporting the executive director.

\section{The Board Chair/Executive Director Relationship}

The final piece of this puzzle is the need to focus on the board chair/executive director relationship. Houle (1997) emphasizes the centrality of this relationship in a 
healthy non-profit organization. Houle notes the importance of a trusting relationship, in which the executive director can utilize the board chair as a confidant and can rely on the board chair to keep the board focused on its responsibilities and not become mired in micromanaging day-to-day operations. In turn, the board chair can rely on the executive director to share important information regularly and transparently so as to ensure that surprises do not derail the organization. DeKuyper (2007) offers a similar perspective, writing, "It is therefore crucial that the chair and the head make every effort to establish a solid and supportive relationship of candor and trust, develop the capacity to be mutually critical, and learn from each other's feedback" (p. 145). The relationship is a complex one, for the board chair also is responsible for ensuring the board conducts a regular evaluation of the executive director and, in the end, for guiding the board to dismiss an executive director if the director is not effectively meeting his or her responsibilities.

At SDMS, the relationship seemed to founder throughout the 16-month period of my study. During the early period, the executive director seemed reticent to share openly and transparently with the board chair, and there did not seem to be a high level of trust. The departure of the executive director, while not necessarily expected, does not seem surprising when looking back at those early meetings and recognizing the executive director's penchant for avoiding difficult conversations and apparent disconnect from the board members. The executive director's focus on the day-to-day operations of the school seemed to impede her ability to nurture and manage the important relationship with the board chair and other members of the board. 
During the second two periods there was no real opportunity to assess the relationship for a permanent executive director was not in place. The complexity surrounding the hiring process, however, does not bode well for the relationship moving forward. The board's initial public stance that the vice principal was not qualified seems bound to create problems, particularly since the board's past does not suggest that it recognizes the need to provide professional development or training to counter this initial assessment.

Ultimately, effective governance is dependent on trust and transparency. The challenges at SDMS underscore the central role that the executive director and board chair play in ensuring the presence of these two essential qualities.

\section{Sunshine Laws in Charter Schools}

Innes and Booher (2004) offer a telling analysis of the impact of Sunshine Laws on governance. Their description of the typical role of opening comment periods at public meetings, for example, closely mimics what happened at SDMS. They describe a process where each person is given a set period of time and the officials either listen passively or, in some cases, do not even listen as they bide their time before the real meeting starts. The process is extremely political as people desperately try to make their point and get the attention of the officials.

During the past 18 months, there were only a handful of meetings where people were present to give public comment. The other meetings, by comparison, were limited almost entirely to members of the board of directors. At each meeting where a large crowd appeared, the atmosphere was emotionally charged and the resulting comments 
were angry, tearful, and often combative. The comments, while clearly getting the attention of the board, never led to thoughtful conversation and the process did not lead to genuine collaboration between the community and the board. Following public comment, nearly all of the community members actually left, meaning they did not even see what was happening at the meeting. Indeed, the appearance of the public at only a few meetings arguably reflected the lack of community engagement in the operations of the board of directors, rather than showcasing the strong commitment of the community to the school. While intended to increase community involvement, the Sunshine Laws generated political tension and created a stormy year for the school, outcomes that arguably could have been avoided with a truly thoughtful and inclusive community conversation run by the board and the executive director.

A review of the Brown Act suggests that part of the problem for the board was a lack of understanding of the act's actual structure. For example, there is no obvious requirement in the act that the board not respond to the public comment period (Lockyer, 2003). Clearly, board education surrounding the Brown Act would be helpful for any charter school attempting to abide by its strictures. Putting that aside, however, the act really does create some tricky challenges for a board hoping to engage in effective governance, particularly generative conversations that require an open, non-politically charged atmosphere. As Innes \& Booher (2004) write,

These "sunshine laws" are designed to assure transparency in government and give citizens the chance to be informed and aware so they can comment appropriately. It is not clear whether these laws have had the intended effect of getting rid of backroom deal-making, but it is clear that they constrain officials from engaging in timely and detailed deliberation around complex issues 
(Bohman, 1996; Boxer-Macomber, 2003) or in using self-organizing collaborative dialogue. (pp. 423-424)

The structure of public comment periods created by Sunshine Laws like the Brown Act frames the conversation from the start as one of combat, with the people needing to speak in a sufficiently impassioned manner as to get the attention of the public officials.

Campbell and Marshall (2000) conducted a study of public hearings in Berkeley and Oakland, California, and noted that "in all the meetings observed, there was a palpable sense of individuals feeling they were engaged in a battle" (p. 330).

The solution for a charter school board of directors is by no means obvious. Clearly, the board of directors cannot disregard the Brown Act. In order to engage in generative thinking, however, the board needs to create an atmosphere in which people can share openly and without fear of political recrimination ideas and solutions to different challenges. A proactive and public adoption of community norms of dialogue, for example, might serve as a helpful starting place in changing the tenor of the comments.

Closely related, public policy experts would be well-served to grapple with the idea that open meetings constrained by a rigid set of bureaucratic rules are the only or even most effective means of creating transparent governance. Scholars of governance should be charged with finding ways to balance the need for transparent and honest governance with the need for boards of directors to create a space where complex problems can be discussed and deliberated in a confidential manner. The solution is not obvious, but a year at SDMS revealed the importance of having the conversation. 


\section{University Partnerships}

The failure of the university partnership represented a profound lost opportunity for SDMS and for the university. Instead of capitalizing on the potential benefits to both groups - the access to educational research and university resources for SDMS, on one hand, and the ability to bridge the research/practice gap and offer an opportunity to allow university students a place to practice their craft, on the other hand-the two institutions became mired in a politically-charged debate that left both sides, in the end, high and dry. Surprisingly, this type of outcome is not as unusual as one might expect. Indeed, the literature on university partnerships is littered with similarly failed efforts (Cushing \& Kohl, 1997, cited in Sanders, 2006; Mawhinney, 1994, cited in Sanders, 2006; Epstein, 2004). Sanders's (2006) list of factors that contribute to a successful partnership-a highfunctioning school, a student-centered environment, effective partnership team, principal leadership and external support—helps explain the problems at SDMS, as the school arguably failed to meet effectively any of the items on the list. Indeed, as noted earlier, there were at least three main problems - the lack of principal leadership, the failure to create an effective partnership between the executive director and the board, the failure to clearly articulate the partnership agreement, and the failure to effectively address the perceived and potential conflicts of interest in having university representatives on the board and conducting research at the school.

The experience offers yet another cautionary note to educational reformers. The notion that partnerships with universities and other organizations offer a panacea for lowperforming schools simply does not hold true. While the potential of these partnerships is 
great, their actual implementation is difficult in an already challenging governance environment. Groups like the California Charter Schools Association (CCSA) could provide an invaluable service to charter schools by offering expertise about and materials focused on supporting the creation of sustainable and successful partnerships. Model partnership agreements, which underscore the potential pitfalls in these relationships, would be a key component of these materials. Finally, boards of directors need to view oversight of these partnerships as a key component to their fiduciary responsibility. Creating sustainable structures to support the partnership —an advisory board, for example, that would report regularly to the board, the school, and the university-would be an important first step to ensuring their long-term viability.

\section{Limitations of the Study}

The SDMS case study offers a detailed view of one conversion charter school's governance challenges during a 16-month period. The context of a conversion charter school is clearly different from that of other start-up charter schools, as a conversion charter represents an effort to renew a school that has a legacy of failure and operating challenges. While it would be difficult to argue that the findings from this study are generalizeable to all charter schools, they do provide a framework by which to examine other charter schools and the viability of the charter school reform effort (Donmoyer, 1990). The resonance of this study's findings with the existing literature in topics such as the role of the executive director, the contested terrain of board governance, and the challenges of maintaining partnerships offers some validation of the study's value. 
The biggest constraint that emerged during the study was the challenge of accessing all of the constituent groups. The tension between SDMS and the university colored the perceptions of some people about this study and led to the unwillingness of several SDMS people to be interviewed despite repeated requests. In particular, the founding executive director and several key faculty members refused interview requests. The lack of these interviews clearly diminished the findings and required me to rely on other interviews and insights gained from attending board meetings. This is particularly true in deconstructing the failure of the partnership, as I had to rely on the perspectives voiced at board meetings and through a small number of documents, rather than being able to really delve into those perceptions and better understand their root causes with interviews. While I believe my findings reflect a reasonable assessment of what happened, I have no doubt they would have been enriched by these further conversations.

\section{Areas for Future Research}

This qualitative case study not only suggests several areas for future research, but highlights the importance of better understanding the impact of governance on the charter school reform effort. The success of charter schools will be highly dependent on the ability of reformers to create sustainable and effective governance structures, something significantly more challenging than many reformers have historically recognized. The promise of autonomy offered by charter schools is appealing to many people, yet the difficult reality of creating and sustaining a charter school reminds people of the limits of that promise. 
One rich area for further study would be a rigorous analysis of successful charter school executive directors. The challenges of this position have been clear from this study. It would be helpful to follow a series of successful leaders to see how they address some of these challenges, including working with a board of directors, balancing day-today management with the need for strategic leadership, and effectively raising money to ensure the school's fiscal viability.

On another track, it would be interesting to conduct a study of a broad group of charter schools to gain a better sense of how the different issues identified in this study play out at different organizations and to better understand which issues are most significant in ensuring the long-term success or failure of different schools. Closely related, it would be important to study the growing cadre of charter management organizations, who have attempted to address some of the governance challenges found in stand-alone charter schools by creating networks of schools that can utilize shared services and benefit from sharing best practices. These organizations may have the ability to address many of the governance problems that occurred at a school like SDMS, while capitalizing on the promise of autonomy that is represented in the charter school reform movement.

\section{Concluding Remarks}

In the end, it would be overly simplistic after cataloging the governance challenges at SDMS to argue that the decision at SDMS to become a conversion charter school made the situation worse for students in their once failing school. Clearly, the campus was safer than it had been prior to the conversion process and at least initially, the 
test scores improved. At the same time, the short-term gains the school had--safer campus, initial improvements in test scores-do not necessarily appear to be sustainable given the governance challenges that occurred during this period. Indeed, the challenges of charter school governance revealed in this study offer a sobering reminder that the charter school reform effort is not a magical silver bullet.

At the same time, the issues impacting charter school governance revealed in this study—role confusion for boards and executive directors, inadequate training for executive directors, difficulty managing partnerships that bring much-needed resources to traditionally under-resourced schools - do not seem insurmountable. Recognition of the underlying tensions that inhere in the governance structure-management versus governance, transparency versus confidentiality, and representation versus trusteeship -would allow charter schools to approach these issues consciously and strategically. While the challenges would not disappear, a highly functioning board and executive director would seem poised to address these challenges in effective ways. Along a similar note, the growth and professionalization of the charter school network through groups such as the CCSA offers another means of addressing these areas. In the end, while this study ultimately raises more questions than it answers, it clearly suggests the importance of focusing on charter school governance in order to better understand the long-term viability of the charter school reform effort. 


\section{REFERENCES}

Alpert, E. (2008, June 10). A rare turnaround for a struggling middle school. Voice of San Diego. Retrieved from http://www.voiceofsandiego.org/education/article ea7f39aab5c5-5375-ae02-aa6bcf921978.html

Bassett, P. (2006, November 1). High season for head searches [Web log post]. Retrieved from http://www.nais.org/about/article.cfm?ItemNumber=149518

Belfield, C. R., \& Levin, H. M. (2005). Privatizing educational choice: Consequences for parents, schools, and public policy. Boulder, CO: Paradigm Publishers.

Berends, M., Springer, M. J., \& Walberg, H. J. (Eds.). (2008). Charter school outcomes. New York, NY: Lawrence Erlbaum Associates.

Betts, J., \& Hill, P. T. (2006, May). Key issues in studying charter schools and achievement: A review and suggestions for national guidelines. Seattle, WA: National Charter School Research Project at the Center on Reinventing Public Education.

Board of Trustees. (2004, December 16). Trustees handbook. Unpublished manuscript.

Buckley, J., \& Schneider, M. (2007). Charter schools: Hope or hype? Princeton, NJ: Princeton University Press.

Bulman, R. C., and Kirp, D. L. (1999). The shifting politics of school choice. In S. D. Sugarman \& F. R. Kemerer (Eds.), School choice and social controversy: Politics, policy, and law (pp. 36-67). Washington, DC: Brookings Institution Press.

California Charter Schools Association. (n.d.). Get the facts. Retrieved from http://www. myschool.org/AM/ContentManagerNet/Default.aspx?Section=About_Charter_ Schools \&Template $=/$ TaggedPage/TaggedPageDisplay.cfm $\&$ TPLID $=\overline{2} \&$ ContentID $=$ 3538

California Department of Education. (n.d.) Testing and accountability. Retrieved from http:cde.ca.gov/ta/

California Education Code. (2004). 34 C.F.R. sec. 47604.

California School Boards Association. (2005). Charter school facilities and Proposition 39: Legal implications for school districts. Advisory. Retrieved from csba.org/ EducationIssues.ashx 
Campbell, H., \& Marshall, R. (2000). Public involvement and planning: Looking beyond the one to the many. International Planning Studies, 5(3), 321-344.

Carnochan, S. (2002). Reinventing government: What urban school districts can learn from charter schools. In A. S. Wells (Ed.), Where charter school policy fails: The problems of accountability and equity (pp. 54-76). New York, NY: Teachers College Press.

Carver, J. (2006). Boards that make a difference: A new design for leadership in nonprofit and public organizations ( $3^{\text {rd }}$ ed.). San Francisco, CA: Jossey-Bass.

Chait, R. P., Ryan, W. P., \& Taylor, B. E. (2005). Governance as leadership: Reframing the work of nonprofit boards. Hoboken, $\mathrm{NJ}$ : Wiley.

Charmaz, K. (2005). Grounded theory in the $21^{\text {st }}$ century. In N. K. Denzin \& Y. Lincoln (Eds.), The Sage handbook of qualitative research (pp. 31-58). Thousand Oaks, CA: Corwin Press.

Charmaz, K., \& Bryant, A. (2007). A grounded theory in historical perspective: An epistemological account. In K. Charmaz \& A. Bryant (Eds.), The Sage handbook of grounded theory (pp. 31-58). Los Angeles, CA: Sage Publications.

Chubb, J. E., \& Moe, T. M. (1990). Politics, markets, and America's schools. Washington, DC: The Brookings Institution.

Coons, E., \& Sugarman, S. D. (1978). Education by choice: The case for family control. Berkeley, CA: University of California Press.

Cordeiro, P. A. (Ed.). (1996). Boundary crossings: Educational partnerships and school leadership. San Francisco, CA: Jossey-Bass.

Corderio, P. A., \& Kolek, M. M. (1996). Introduction: Connecting school communities through educational partnerships. In P. A. Cordeiro (Ed.), Boundary crossings: Educational partnerships and school leadership (pp. 1-14). San Francisco, CA: Jossey-Bass.

Cornell-Feist, M. (2007, September). Good to govern: Evaluating the capacity of charter school founding boards. National Association of Charter School Authorizers [Authorizing Matters Issue Brief]. Retrieved from http://www.qualitycharters. org/i4a/pages/Index.cfm?pageID $=3662$

Corwin, J., \& Schneider, R. J. (2005). The school choice hoax: Fixing America's schools. Westport, CT: Praeger Publishers. 
Crowson, R. L., \& Boyd, W. (1993). Coordinated services for children: Designing arks for storms and seas unknown. American Journal of Education, 101, 140-179.

Darling-Hammond, L. (Ed.). (1994). Professional development schools: Schools for developing a profession. New York, NY: Teachers College Press.

Deal, T. E., \& Hentschke, G. C. (2004). Different wine in different bottles: Entrepreneurial leaders for charter schools. UrbanEd, 30-48.

DeKuyper, M. H. (2007). The trustee handbook: A guide to effective governance for independent school boards $\left(9^{\text {th }}\right.$ ed.). Washington, DC: National Association of Independent Schools.

Dey, I. (2007). Grounding categories. In A. Bryant \& K. Charmaz (Eds.), The Sage handbook of grounded theory. Los Angeles, CA: Sage Publications.

Donmoyer, R. (1990). Generalizability and the single-case study. In E. Eisner \& A. Peshkin (Eds.), Qualitative research in education: The debate continues (pp. 175200). New York, NY: Teachers College Press.

Esptein, N. (Ed.). (2004). Who's in charge here? The tangled web of school governance and policy. Washington, DC: Brookings Institution Press.

Farland, S. (2005). Charter school facilities and Proposition 39: Legal implications for school districts. Sacramento, CA: Charter School Board Association.

Finn, C. E., \& Hill, P. T. (2006). Authorizing: The missing link. In P. T. Hill (Ed.), Charter schools against the odds: An assessment of the Koret Task Force on K-12 Education (pp. 103-126). Stanford, CA: Hoover Press.

Flanagan, K. (2008, November 12). Survey of charter schools in San Diego Unified. Unpublished manuscript. Commissioned by California Charter School Associaiton. Funded by Girard Foundation. Findings shared with SDUSD and CCSA.

Fuller, B. (Ed.). (2000). Inside charter schools: The paradox of radical decentralization. Cambridge, MA: Harvard University Press.

Glesne, C. (2006). Becoming qualitative researchers: An introduction $\left(3^{\text {rd }} \mathrm{ed}.\right)$. Boston, MA: Pearson Education.

Godwin, R. K., \& Kemerer, F. R. (2002). School choice tradeoffs: Liberty, equity, and diversity. Austin, TX: University of Texas Press. 
Goodlad, J. I. (1988). School-university partnerships for educational renewal: Rationale and concepts. In K. A. Sirotnik \& J. I. Goodlad (Eds.), School-university partnerships in action: Concepts, cases, and concerns (pp. 1-31). New York, NY: Teachers College Press.

Greene, J. P., Forster, G., \& Winters, M. A. (2003, July). Apples to apples: An evaluation of charter schools serving general student populations. Center for Civic Innovation at the Manhattan Institute [Education Working Paper No. 1]. Retrieved from http://www.manhattan-institute.org/html/ewp_01.htm

Hassel, B. C., \& Terrell, M. G. (2006, October). Charter school achievement: What we know. National Alliance for Public Charter Schools. Retrieved from http://www. publiccharters.org

Heifetz, R. (1994). Leadership without easy answers. Cambridge, MA: Harvard University Press.

Henig, J. R. (1999). School choice outcomes. In S. D. Sugarman \& F. R. Kemerer (Eds.), School choice and social controversy: Politics, policy, and law (pp. 68-110). Washington, DC: Brookings Institution Press.

Henig, J. R., Holyoke, T. T., Brown, H., \& Lacireno-Paquet, N. (2005, August). The influence of founder type on charter school structures and operations. American Journal of Education, 111, 487-514.

Henig, J. R., Holyoke, T. T., Lacireno-Paquet, \& Moser, M. (2001). Growing pains: An evaluation of charter schools in the District of Columbia: 1999-2000. Report prepared for the Eugene and Agnes Meyer Foundation. Retrieved from http:/www. gnu.edu/ gwipp/cwaspubs.htm

Henig, J. R., \& Sugarman, S. D. (1999). The nature and extent of school choice. In S. D. Sugarman \& F. R. Kemerer (Eds.), School choice and social controversy: Politics, policy, and law (pp. 13-35). Washington, DC: Brookings Institution Press.

Herman, R. D. (2005). The Jossey-Bass handbook of nonprofit leadership and management $\left(2^{\text {nd }}\right.$ ed). San Francisco, CA: Jossey-Bass.

Hill, P. T. (1999). The supply side of school choice. In S. D. Sugarman \& F. R. Kemerer (Eds.), School choice and social controversy: Politics, policy, and law (pp. 140-173). Washington, DC: Brookings Institution Press. 
Hill, P. T. (2004). Recovering from an accident: Repairing governance with comparative advantage. In N. Esptein (Ed.), Who's in charge here? The tangled web of school governance and policy (pp. 75-113). Washington, DC: Brookings Institution Press.

Hill, P. T. (Ed.) (2006). Charter schools against the odds: An assessment of the Koret Task Force on K-12 Education. Stanford, CA: Hoover Press.

Hill, P. T., \& Lake, R. J. (2008). Charter school governance. In M. Berends, M. J. Springer, \& H. J. Walberg (Eds.), Charter school outcomes (pp. 113-130). New York, NY: Lawrence Erlbaum Associates.

Houle, C. O. (1997). Governing boards. San Francisco, CA: Jossey-Bass.

Howells, W. G. (Ed.). (2005). Besieged: School boards and the future of education politics. Washington, DC: Brookings Institution Press.

Hoxby, C. M. (2004, September). A straightforward comparison of charter schools and regular public schools in the United States. Harvard University and National Bureau of Economic Research. Retrieved from http://www.uscharterschools.org/cs/r/view/ uscs_rs/1989

Hoxby, C. M., \& Rockoff, J. E. (2005, Fall). Findings from the City of Big Shoulders. Education Next, 5(4). Retrieved from http://www.hoover.org/publications/ ednext/3217766.html

Innes, J. E., \& Booher, D. E. (2004). Reframing public participation: Strategies for the $21^{\text {st }}$ century. Planning Theory \& Practice, 5(4), 419-436.

Johnston, M. (with the Educators for Collaborative Change). (1997). Contradictions in collaboration: New thinking on school/university partnerships. New York, NY: Teachers College Press.

Kemerer, F., \& Ausbrooks, C. (1996). Summary: Student survey report of the San Antonio school choice research project. Denton, TX: University of North Texas, Center for the Study of Education Reform.

Landsberg, M., Smith, D., \& Blume, H. (2010, January 10). L.A. charter schools flex their educational muscles. Retrieved from http://articles.latimes.com/2010/ jan/10/local/la-me-charters10-2010jan10

Laughlin, F. L., \& Andringa, R. C. (2007). Good governance for nonprofits: Developing principles and policies for an effective board. New York, NY: AMACOM. 
Levin, B. (1999). Race and school choice. In S. D. Sugarman \& F. R. Kemerer (Eds.), School choice and social controversy: Politics, policy, and law (pp. 266-299). Washington, DC: Brookings Institution Press.

Levin, H. M. (2004). Multiple "choice" questions: The road ahead. In N. Epstein (Ed.), Who's in charge here? The tangled web of school governance and policy (pp. 228255). Washington, DC: Brookings Institution Press.

Levine, M., \& Trachtman, R. (Eds.). (1997). Making professional development schools work: Politics, practice, and policy. New York, NY: Teachers College Press.

Lockyer, B. (2003). The Brown Act: Open meetings for local legislative bodies. California, Office of the Attorney General. Retrieved from http://ag.ca.gov/ publications/2003_Intro_BrownAct/pdf

Lopez, A., Wells, A. S., \& Holmes, J. J. (2002). Creating charter school communities: Identity building, diversity, and selectivity. In A. Wells (Ed.), Where charter school policy fails: The problems of accountability and equity (pp. 129-157). New York, NY: Teachers College Press.

McClure, L., Strick, B., Jacob-Almedia, R., \& Reicher, C. (2005, November). The Preuss School at UCSD: School characteristics and students' achievement. University of California, San Diego. The Center for Research on Educational Equity, Assessment and Teaching Excellence. Retrieved from http://create.ucsd.edu/Research_ Evaluation/PreussReportDecember2005.pdf

Merrow, J. (2007, August 15). Failing San Diego schools work to meet standards. The NewsHour [Television broadcast]. New York, NY: Public Broadcasting Service.

Miron, G., \& Nelson, C. (Eds.). (2002). What's public about charter schools? Lessons learned about choice and accountability. Thousand Oaks, CA: Corwin Press.

Miron, G., Nelson, C., \& Lubienski, C. (2002). Charter schools and privatization. In G. Miron \& C. Nelson (Eds.), What's public about charter schools? Lessons learned about choice and accountability (pp. 1-17). Thousand Oaks, CA: Corwin Press.

Nelson, F. H., Rosenberg, B., \& Van Meter, N. (2004, August). Charter school achievement on the 2003 National Assessment of Educational Progress. American Federation of Teachers, AFL-CIO. Retrieved from http://www.aft.org/pubsreports/downloads/teachers/NAEPCharterSchoolReport.pdf

Orfield, G., \& Yun, J. T. (1999). Resegregation in American schools. Harvard University Civil Rights Project. Cambridge, MA: Harvard University Press. 
Osberg, E. (2006). Charter school funding. In P. T. Hill (Ed.), Charter schools against the odds: An assessment of the Koret Task Force on K-12 Education (pp. 45-69). Stanford, CA: Hoover Press.

Reardon, S. F., \& Yun, J. T. (2002). Private school racial enrollments and segregation. Cambridge, MA: The Civil Rights Project, Harvard University Press.

Restine, L. N. (1996). Partnerships between schools and institutions of higher education. In P. A. Cordeiro (Ed.), Boundary crossings: Educational partnerships and school leadership (pp. 31-40). San Francisco, CA: Jossey-Bass.

Sanders, M. G. (2006). Building school-community partnerships: Collaboration for student success. Thousand Oaks, CA: Corwin Press.

Scott, J., \& Holmes, J. J. (2002). Public schools, private resources: The role of social networks in California charter school reform. In A. S. Wells (Ed.), Where charter school policy fails: The problems of accountability and equity (pp. 102-128). New York, NY: Teachers College Press.

Sirotnik, K. A., \& Goodlad, J. I. (Eds.). (1988). School-university partnerships in action: Concepts, cases, and concerns. New York, NY: Teachers College Press.

Slayton, J. (2002). Public funds for California charter schools: Where local context and savvy meet formula. In A. S. Wells (Ed.), Where charter school policy fails: The problems of accountability and equity (pp. 77-101). New York, NY: Teachers College Press.

Smarick, A. (2008, Winter). Waves of the future. Education Next, 8(1). Retrieved from http://www.hoover.org/publications/ednext/11130241.html

Smith, J., \& Wells, J. (2006). Overview of charter school facility development and financing. Low Income Investment Fund, Report to the Community, no. 4.

Smith, J., Wohlstetter, P., \& Brewer, D. J. (2007). Under new management: Are charter schools making the most of new governance options? In R. J. Lake (Ed.), Hopes, fears, and reality: A balanced look at American charter schools in 2007 (pp. 17-28). National Charter School Research Project Center on Reinventing Public Education, Daniel J. Evans School of Public Affairs. Seattle, WA: University of Washington.

Smith, N. (2007, Winter). Charters as a solution? Education Next, 7(1). Retrieved from http://www.hoover.org/publications/ednext/4612437.html 
Speakman, S. T. (2008). Back to the future: Sustaining an equitable public-private model of school funding. In M. Berends, M. J. Springer, \& H. J. Walberg (Eds.), Charter school outcomes (pp. 85-112). New York, NY: Lawrence Erlbaum Associates.

Stake, R. (2005). Qualitative case studies. In N. K. Denzin \& Y. Lincoln (Eds.), The Sage handbook of qualitative research (pp. 443-466). Thousand Oaks, CA: Corwin Press.

Sugarman, S. D. (1999). School choice and public funding. In S. D. Sugarman \& F. R. Kemerer (Eds.), School choice and social controversy: Politics, policy, and law (pp. 111-139). Washington, DC: Brookings Institution Press.

Sugarman, S. D., \& Kemerer, F. R. (Eds.). (1999). School choice and social controversy: Politics, policy, and law. Washington, DC: Brookings Institution Press.

Teitel, L. (2003). The professional development schools handbook: Starting, sustaining, and assessing partnerships that improve student learning. Thousand Oaks, CA: Corwin Press.

Teske, P., Schneider, M., \& Cassese, E. (2005). Local schools boards as authorizers of charter schools. In W. G. Howells (Ed.), Besieged: School boards and the future of education politics (pp. 129-355). Washington, DC: Brookings Institution Press.

U.S. Charter Schools. (n.d.). Benefits. Retrieved from http://www.uscharterschools. org.pub/uscs_docs/o/index.htm

U.S. Department of Education. (2001). Academic assessment and local educational agency and school improvement. Retrieved from http://www.ed.gov/policy/ elsec/leg/esea02/pg2.html\#sec1116

Wells, A. S. (Ed.). (2002). Where charter school policy fails: The problems of accountability and equity. New York, NY: Teachers College Press.

Wells, A. S., Vasudeva, A., Holmes, J. J., \& Cooper, C. W. (2002) The politics of accountability: California school districts and charter school reform. In A. S. Wells (Ed.), Where charter school policy fails: The problems of accountability and equity (pp. 29-53). New York, NY: Teachers College Press.

Widmer, C. (1993). Role ambiguity and role overload on boards of directors of nonprofit human service organizations. Nonprofit and Voluntary Sector Quarterly, 22, 339-356.

Williams, J. (2007, Winter). Games charter opponents play. Education Next, 7(1). Retrieved from http://www.hoover.org/publications/ednext/4611587.html 
Wohlstetter, P., Malloy, C. L., Hentschke, G. C., \& Smith, J. (2004, December). Improving service delivery in education through collaboration: An exploratory study of the role of cross-sectoral alliances in the development and support of charter schools. Social Science Quarterly, 85(5), 1078-1096.

Yin, R. K. (2003). Case study research design and methods ( $3^{\text {rd }}$ ed.). Thousand Oaks, CA: Sage Publications.

Zimmer, R., \& Buddin, R. (2008). Charter schools in California. In M. Berends, M. J. Springer, \& H. J. Walberg (Eds.), Charter school outcomes (pp. 163-194). New York, NY: Lawrence Erlbaum Associates. 
Appendix A

Board Meetings Attended 
Board Meetings Attended

2008-2009 School Year

February 4, 2008

March 3, 2008

April 7, 2008

May 5, 2008

June 2, 2008

June 30, 2008

2009-2010 School Year

October 6, 2008

December 1, 2008

January 5, 2009

February 2, 2009

March 2, 2009

April 6, 2009

June 2009 
Appendix B

Analysis of Interview Guide and Rationale for Each Question 


\section{Analysis of Interview Guide and Rationale for Each Question}

\begin{tabular}{|c|c|}
\hline Interview Questions & Justification \\
\hline \multicolumn{2}{|l|}{ Personal Background } \\
\hline $\begin{array}{l}\text { How did you get involved } \\
\text { with the school? How } \\
\text { long have you served on } \\
\text { the BOD? }\end{array}$ & $\begin{array}{l}\text { This information was important for understanding how the board } \\
\text { was constituted, and for determining what attracted individuals to } \\
\text { become members of the board (commitment to mission, parental } \\
\text { connection, connection to board member, etc). }\end{array}$ \\
\hline $\begin{array}{l}\text { What do you do } \\
\text { professionally? How, in } \\
\text { your mind, does this } \\
\text { connect with the work of } \\
\text { the BOD? }\end{array}$ & $\begin{array}{l}\text { This question attempts to capture the skill-set of the board of } \\
\text { trustees, with an eye toward better understanding both areas of } \\
\text { strength and weakness on the board. }\end{array}$ \\
\hline $\begin{array}{l}\text { Role of the Board of } \\
\text { Directors }\end{array}$ & $\begin{array}{l}\text { This category and its related questions emerged primarily from } \\
\text { the non-profit and charter school governance literature, although } \\
\text { also from observations at board meetings that suggested some } \\
\text { confusion both among different constituent groups and among the } \\
\text { board itself. }\end{array}$ \\
\hline $\begin{array}{l}\text { What role do you think a } \\
\text { charter school board of } \\
\text { directors should play? }\end{array}$ & $\begin{array}{l}\text { This question attempts to capture the perceptions of BOD } \\
\text { members about their own role, as well as in other interviews gain } \\
\text { a sense of best practices about BOD operations or perceptions of } \\
\text { other community members about this role. Observations of } \\
\text { meetings and the literature suggest that there is often confusion or } \\
\text { differing perceptions about this role. }\end{array}$ \\
\hline $\begin{array}{l}\text { How do you think the } \\
\text { BOD role connects with } \\
\text { the role of other } \\
\text { constituent groups: school } \\
\text { district, school } \\
\text { administration, } \\
\text { faculty/staff, parents }\end{array}$ & $\begin{array}{l}\text { This question attempts to further understand how BOD members } \\
\text { and other interview subjects perceive the role of the BOD. By } \\
\text { asking about the role vis a vis other roles I am trying to discern } \\
\text { how people distinguish these roles and if they have a clear sense } \\
\text { of how the roles diverge and intersect. }\end{array}$ \\
\hline $\begin{array}{l}\text { How closely has the role } \\
\text { that the BOD has played } \\
\text { during the early years } \\
\text { matched your } \\
\text { expectations for an } \\
\text { effective charter school } \\
\text { BOD? }\end{array}$ & $\begin{array}{l}\text { This question attempts to capture board perceptions of the } \\
\text { group's efficacy. It is yet another way to better understand what } \\
\text { role the board thinks it should play and, particularly given the } \\
\text { tumultuous events of the year, offers an opportunity to get insight } \\
\text { into what board members see as strengths and weaknesses of the } \\
\text { group. }\end{array}$ \\
\hline $\begin{array}{l}\text { What areas have been } \\
\text { strengths for this Board? } \\
\text { Weaknesses? }\end{array}$ & $\begin{array}{l}\text { This question, while not always asked, allowed development of } \\
\text { the previous answer and was a more direct means of getting at the } \\
\text { issue. }\end{array}$ \\
\hline
\end{tabular}




\begin{tabular}{|c|c|}
\hline SDMS's Early Years & $\begin{array}{l}\text { This category was intended to capture some of the institutional } \\
\text { memory and to better understand the rationale for becoming a } \\
\text { conversion charter school. Parts of this category were not asked } \\
\text { of all board members, as not every member had been an original } \\
\text { member of the board. }\end{array}$ \\
\hline $\begin{array}{l}\text { SDMS's original decision } \\
\text { to become a charter } \\
\text { school occurred at a time } \\
\text { when the school had to } \\
\text { undergo a dramatic } \\
\text { transformation. What } \\
\text { benefits were there to } \\
\text { SDMS for its decision to } \\
\text { adopt a charter school } \\
\text { structure? }\end{array}$ & $\begin{array}{l}\text { This question attempted to determine people's perspective on the } \\
\text { decision by SDMS to become a charter school. Part of the } \\
\text { question was an underlying interest in how well people could } \\
\text { articulate a rationale for the decision. A well-articulated rationale } \\
\text { and something that was consistent across different people would } \\
\text { suggest a clear founding story and a shared understanding of the } \\
\text { school's original mission and vision. }\end{array}$ \\
\hline $\begin{array}{l}\text { How would you } \\
\text { characterize the school's } \\
\text { early years? What were } \\
\text { the school's biggest } \\
\text { successes? Biggest } \\
\text { challenges? }\end{array}$ & $\begin{array}{l}\text { This was intended to reveal challenges and success of the early } \\
\text { years. These answers might offer insight into some of the issues } \\
\text { currently affecting the school, as well as suggest if those issues } \\
\text { have changed over time. Since I was not present in the early } \\
\text { years, I thought it was also important to learn a little about the } \\
\text { early history. }\end{array}$ \\
\hline $\begin{array}{l}\text { Did anything surprise you } \\
\text { in the school's early } \\
\text { years? }\end{array}$ & $\begin{array}{l}\text { This was intended to uncover topics that I might not have thought } \\
\text { about, as well as gain insight into any surprises that arose as part } \\
\text { of the transition to a charter school. }\end{array}$ \\
\hline $\begin{array}{l}\text { Autonomy and } \\
\text { Accountability }\end{array}$ & $\begin{array}{l}\text { This was a key category that forced respondents to move beyond } \\
\text { the abstract notions of the role of the board and to review what } \\
\text { the board actually did. The terms are directly from the literature } \\
\text { on charter schools, as well as much of the public debate } \\
\text { surrounding charter schools. }\end{array}$ \\
\hline $\begin{array}{l}\text { At the heart of the charter } \\
\text { school concept, is the } \\
\text { notion that schools will } \\
\text { receive greater autonomy } \\
\text { in exchange for increased } \\
\text { accountability. What } \\
\text { types of autonomy do you } \\
\text { think SDMS has gained } \\
\text { through this bargain? }\end{array}$ & $\begin{array}{l}\text { This question and the ensuing question were an effort to see how } \\
\text { well the board members understood the purported advantages of } \\
\text { charter schools and whether they saw evidence of those } \\
\text { advantages in the operation of the school. }\end{array}$ \\
\hline $\begin{array}{l}\text { How does the SDMS } \\
\text { Board of Directors hold } \\
\text { the school accountable? } \\
\text { How does it determine if } \\
\text { the school is fulfilling its } \\
\text { mission and meeting its } \\
\text { performance targets? }\end{array}$ & $\begin{array}{l}\text { This question, in addition to unpacking board understanding of } \\
\text { charter schools, also pointed to the heart of the fiduciary role of a } \\
\text { non-profit board of directors. Did the board understand that role } \\
\text { and was it consciously playing it? }\end{array}$ \\
\hline
\end{tabular}




\begin{tabular}{|c|c|}
\hline $\begin{array}{l}\text { Does the school have a } \\
\text { clear vision? How is that } \\
\text { vision shaped? Who is } \\
\text { responsible for creating } \\
\text { and sustaining that vision? }\end{array}$ & $\begin{array}{l}\text { This question was an effort to consider the board's strategic and } \\
\text { generative roles and to determine what, if any, efforts were being } \\
\text { made in these areas. It was also an effort to indirectly unpack the } \\
\text { relationship between the executive director and the board. }\end{array}$ \\
\hline $\begin{array}{l}\text { Relationship with the } \\
\text { School District }\end{array}$ & $\begin{array}{l}\text { This category emerged during the early meetings, as it became } \\
\text { clear that the management of this relationship was a key } \\
\text { challenge for the school. }\end{array}$ \\
\hline $\begin{array}{l}\text { During the last year, } \\
\text { several key issues have } \\
\text { arisen at board meetings } \\
\text { concerning the district. } \\
\text { Can you explain your } \\
\text { understanding of these } \\
\text { issues and what role, if } \\
\text { any, the BOD has played } \\
\text { in helping to resolve } \\
\text { them? - the lack of a } \\
\text { Memorandum of } \\
\text { Understanding (MOU) } \\
\text { between the district and } \\
\text { the school; - the decision } \\
\text { about whether or not to } \\
\text { stay within the school } \\
\text { district special education } \\
\text { local plan area (SELPA) } \\
\text { or seek another option } \\
\text { outside the district; - the } \\
\text { battle to obtain adequate } \\
\text { facilities from the school } \\
\text { district to support the } \\
\text { school's programs }\end{array}$ & $\begin{array}{l}\text { This question was an effort to better understand the particular } \\
\text { details of the issues between the school district and the school, as } \\
\text { well as gain a sense of how well individual board members } \\
\text { understood these issues. It also offered an opportunity to } \\
\text { understand how individual board members played a role in the } \\
\text { resolution of these issues. }\end{array}$ \\
\hline $\begin{array}{l}\text { How would you } \\
\text { characterize the } \\
\text { relationship between KLA } \\
\text { and the school district? }\end{array}$ & $\begin{array}{l}\text { This question is connected to the issues that had arisen at the } \\
\text { meetings - and is also a key issue addressed in the charter school } \\
\text { literature. }\end{array}$ \\
\hline $\begin{array}{l}\text { Are there ways that the } \\
\text { Board of Directors could } \\
\text { better manage the } \\
\text { relationship with the } \\
\text { school district? }\end{array}$ & $\begin{array}{l}\text { This question attempted to gain insight from a board perspective } \\
\text { of their role vis a vis these issues. It also provided another } \\
\text { opportunity to learn about specific actions that board members } \\
\text { took, or didn't take, that might have helped resolve these issues. }\end{array}$ \\
\hline
\end{tabular}




\begin{tabular}{|c|c|}
\hline $\begin{array}{l}\text { Relationship with } \\
\text { Partner University }\end{array}$ & $\begin{array}{l}\text { This was a major issue throughout the year and thus became a } \\
\text { key topic to address in interviews. }\end{array}$ \\
\hline $\begin{array}{l}\text { One of the biggest } \\
\text { conflicts during the past } \\
\text { year has revolved around } \\
\text { the relationship between } \\
\text { USD and KLA. How } \\
\text { would you characterize } \\
\text { the relationship between } \\
\text { the two partner } \\
\text { organizations? }\end{array}$ & $\begin{array}{l}\text { This was an effort to gain insight into board perspectives on this } \\
\text { issue. The open-ended nature of this question was intended to } \\
\text { elicit stories and information that might add to the information } \\
\text { that was already gleaned from board meetings. }\end{array}$ \\
\hline $\begin{array}{l}\text { What benefits could each } \\
\text { side take away from this } \\
\text { partnership? }\end{array}$ & $\begin{array}{l}\text { This question came directly out of board meetings, where it } \\
\text { became apparent that it was not clear to different groups what the } \\
\text { value of the relationship was. The hope was that this question } \\
\text { would reveal different perceptions about the benefits of the } \\
\text { relationship. }\end{array}$ \\
\hline $\begin{array}{l}\text { What role should the } \\
\text { BOD play in managing } \\
\text { this partnership? }\end{array}$ & $\begin{array}{l}\text { This question went to the heart of board governance - did the } \\
\text { board have a role in helping to manage this relationship? It also } \\
\text { provided an opportunity for board members to mention things } \\
\text { they had done in order to help resolve these issues. }\end{array}$ \\
\hline $\begin{array}{l}\text { Why, in your opinion, has } \\
\text { the relationship been so } \\
\text { challenging? }\end{array}$ & $\begin{array}{l}\text { A direct question intended to gain different perspectives on this } \\
\text { conflict. }\end{array}$ \\
\hline $\begin{array}{l}\text { What do you think should } \\
\text { happen to the partnership? }\end{array}$ & $\begin{array}{l}\text { An important question which made it clear that the future of the } \\
\text { partnership was not preordained. The question gave board } \\
\text { members an opportunity to build on their previous answers and } \\
\text { assess if, in the end, the partnership was worth preserving. }\end{array}$ \\
\hline Fundraising & $\begin{array}{l}\text { This is a key role on many non-profit boards, thus a logical topic } \\
\text { to raise with a board. In addition, this came up at several board } \\
\text { meetings, thus offering an opportunity to ask questions and better } \\
\text { understand the reality of the situation. }\end{array}$ \\
\hline $\begin{array}{l}\text { At several meetings, } \\
\text { people have noted that } \\
\text { this is not a fundraising } \\
\text { board. To your mind, } \\
\text { what does that mean? } \\
\text { What, if anything, should } \\
\text { the BOT do about that? }\end{array}$ & $\begin{array}{l}\text { An effort to understand what people thought was meant by } \\
\text { comments made at board meetings. It also raised the question of } \\
\text { whether or not the board should consider this a major issue } \\
\text { moving forward. }\end{array}$ \\
\hline $\begin{array}{l}\text { How does the conflict } \\
\text { over fundraising connect } \\
\text { with broader concerns } \\
\text { about the BOT? }\end{array}$ & $\begin{array}{l}\text { This question was an effort to see if board members thought the } \\
\text { fundraising concerns were part of broader concerns within the } \\
\text { community about the partnership and the efficacy of the board, or } \\
\text { if they were simply part of the typical non-profit development } \\
\text { challenge. }\end{array}$ \\
\hline
\end{tabular}




\begin{tabular}{|l|l|}
\hline $\begin{array}{l}\text { Community and } \\
\text { Organizational Context }\end{array}$ & $\begin{array}{l}\text { This is a key topic at charter schools, as the suggestion is often } \\
\text { made that charter schools offer increased community } \\
\text { involvement. These questions were an effort to build on } \\
\text { observations at the board meeting and gain a better sense of the } \\
\text { degree of community involvement and the role of the board in } \\
\text { encouraging these connections. }\end{array}$ \\
\hline $\begin{array}{l}\text { How has the community } \\
\text { continued to be involved } \\
\text { in SDMS's development? }\end{array}$ & $\begin{array}{l}\text { This question was an effort to gain insight into how the } \\
\text { involvement of the community has shifted over time. The } \\
\text { question presumed early involvement, based on knowledge of the } \\
\text { school's early years, and thus was probing to see if that } \\
\text { involvement was still true. }\end{array}$ \\
\hline $\begin{array}{l}\text { On the website, the } \\
\text { history mentions that } \\
\text { people felt that SDMS } \\
\text { was "My school." Do } \\
\text { people still think of it as } \\
\text { "My School?" Why or } \\
\text { why not? }\end{array}$ & $\begin{array}{l}\text { This question, similar to the previous question, was an effort to } \\
\text { see how the sense of community has evolved over time. }\end{array}$ \\
\hline $\begin{array}{l}\text { How familiar are you with } \\
\text { the community } \\
\text { surrounding Keiller? }\end{array}$ & $\begin{array}{l}\text { This question was an effort to see how well board members knew } \\
\text { the community. One of the issues on many boards is that } \\
\text { members do not have a strong connection to the community. In } \\
\text { addition, during the study, there was a perception that a deficit } \\
\text { model of the community existed. One way to find out about that } \\
\text { was to see how people described the community. }\end{array}$ \\
\hline $\begin{array}{l}\text { What is the community } \\
\text { like? Who lives here? }\end{array}$ & $\begin{array}{l}\text { This question, similar to the previous question, attempted to see } \\
\text { how well members of the board knew the community. }\end{array}$ \\
\hline
\end{tabular}

